\title{
Pamięć przyswojona.
}

\section{Koncepcja polskiego doświadczenia zagłady Żydów jako traumy zbiorowej w świetle rewizji kategorii świadka}

\author{
Elżbieta Janicka
}

\begin{abstract}
Abstrakt: Artykuł przedstawia rekonstrukcję i proponuje dekonstrukcję koncepcji polskiego doświadczenia Zagłady jako traumy zbiorowej. Kontekst analityczny stanowi rewizja takich kategorii, jak: polski świadek Zagłady (bystander/onlooker - za Hilbergiem) i obojętność wobec Zagłady. Tekst postuluje wykreślenie kategorii obojętności ze słownika opisu Zagłady. Kategorię świadka (bystander/onlooker) proponuje zastąpić kategorią obserwatora uczestniczącego w rozumieniu innym niż przyjęte w antropologii kulturowej. Spojrzenie stanowiłoby tutaj formę aktywności, oddziaływania, sprawczości (agency), a więc uczestnictwa. Istotna część wywodu to próba odpowiedzi na pytanie o konstrukcję owego spojrzenia stanowiącego najbardziej podstawową formę władzy (le droit de regard - za Foucault i Bourdieu). Pojawia się pytanie, czy obrzeża Zagłady można opisać w kategoriach rzeczywistości panoptycznej (le panoptisme - za Foucault). Kolejna rozważana kwestia to, czy większość dominującą można ukazać jako nieformalną instancję sprawującą rodzaj kontroli społecznej nad kompletnością Zagłady jako niemieckiej zbrodni państwowej.

W centrum namysłu znajdują się także dotychczasowe funkcje kategorii świadka (bystander/onlooker), kategorii obojętności oraz koncepcji Zagłady jako traumy nieżydowskiego świadka. Funkcje te niejednokrotnie bowiem polegały na eliminacji z pola widzenia historycznego konkretu i jego społeczno-kulturowych uwarunkowań. W tym sensie można mówić o koncepcji pamięci nieprzyswojonej (polskiej traumy Zagłady) jako strategii przyswojenia pamięci Zagłady w sposób niezagrażający dominującej opowieści o przeszłości i tożsamości grupy większościowej. Tekst proponuje ponadto dekonstrukcję kategorii dialogu polsko-żydowskiego ze wskazaniem na zjawiska fałszywej symetrii i fałszywej uniwersalizacji, których częstą konsekwencją jest definiowanie antysemityzmu i Zagłady w kategoriach konfliktu międzygrupowego. Inspiracją do podjęcia namysłu była paradygmatyczna praca Michaela C. Steinlaufa Bondage to the Dead: Poland and the Memory of the Holocaust z 1997 roku, której polskie wydanie - zatytułowane Pamięć nieprzyswojona. Polska pamięć Zagłady ukazało się w roku 2001 w tłumaczeniu Agaty Tomaszewskiej.

Wyrażenia kluczowe: polska trauma Zagłady (rewizja kategorii); świadek Zagłady; bystander/onlooker (rewizja kategorii); obojętność wobec Zagłady (rewizja kategorii); dialog polsko-żydowski (rewizja kategorii); obserwator uczestniczący; panoptyzm; społeczna kontrola nad Zagładą; obrzeża Zagłady; pamięć kulturowa; dyskurs antysemicki; mit żydokomuny
\end{abstract}

Polskie doświadczenie zagłady Żydów jako trauma zbiorowa. Koncepcja ta od końca lat dziewięćdziesiątych XX wieku cieszy się powodzeniem w polskiej humanistyce. „Polska trauma Zagłady”, „trauma świadka”, stała się pojęciem obiegowym również w języku debaty publicznej. Do dziś praktycznie nie podjęto namysłu nad adekwatnością zastosowania w polskim kontekście i w odniesieniu do grupy zewnętrznej wobec ofiar narzędzi teoretycznych wypracowanych w odniesieniu do ofiar na gruncie transatlantyckiej kultury posttraumatycznej. Ujmowaniu polskiego doświadczenia zagłady Żydów jako traumy zbiorowej nie towarzyszy zazwyczaj rekonstrukcja kontekstu historycznego, bez czego nie sposób odtworzyć zawartości ubytków narracyjnych charakterystycznych dla polskiej opowieści większościowej. Brak też analizy kontekstu komunikacyjnego - nadawczego i odbiorczego - niezbędnego dla określenia stawek rozgrywanych w komunikacji i braku komunikacji. Brak zróżnicowania sytuacji podmiotów nadawczych 
z racji ich przynależności do grupy dominującej lub podporządkowanej. W efekcie, w ramach refleksji nad tzw. traumą świadka napisano i wypowiedziano w Polsce wiele słów, które - w sposób niezamierzony, lecz faktyczny - utworzyły skuteczną zaporę przed próbami rekonstrukcji i zrozumienia polskiego doświadczenia Zagłady. Zablokowały też wydobycie na pierwszy plan i rewizję wzorów kultury dominującej, które stanowiły podŁoże i zapewniały społeczno-kulturową prawomocność przemocy wymierzonej w Żydów.

Aby oszacować konsekwencje owej blokady, warto sięgnąć do początków i przyjrzeć się tekstowi założycielskiemu dla paradygmatu traumatycznego w polskim kontekście badawczym. Na tle prac późniejszych książka Michaela C. Steinlaufa Pamięć nieprzyswojona (1997) 1 stanowi lekturę nietypową. Z jednej strony bowiem Steinlauf proponuje konceptualizację polskiego doświadczenia Zagłady jako traumy zbiorowej. Z drugiej zaś operuje gruntowną wiedzą na temat kultury i historii Polski, które postrzega i opisuje jako zespół procesów długiego trwania. Obecne w wywodzie badacza dwa nurty - traumatyczny i faktograficzny - nie przystają do siebie. Wymagają nieustannych i ostatecznie daremnych - uzgodnień. Ponieważ jednak Steinlauf nie zdecydował się na manipulację faktami, zabieg tak prosty, jak sporządzenie indeksu rzeczowego w trakcie lektury, pozwala wypiętrzyć się zjawiskom nienazwanym wprost i zobaczyć obraz wymagający dalszych, innych rozpoznań.

Książka Michaela C. Steinlaufa nie doczekała się w Polsce debaty². W trzech recenzjach, z których dwie ukazały się przed publikacją jej polskiego tłumaczenia, otrzymała natomiast jednobrzmiące pochwały za właściwość tyleż niewątpliwą, co pozamerytoryczną:

„Steinlauf świadomy był niebezpieczeństw i «delikatności» materii swej pracy. Jak napisat już jeden z krytyków książki, «Autor dość zręcznie pokonał pole minowe polskiej i żydowskiej wrażliwości» [Dariusz Stola, Michael C. Steinlauf, „Bondage to the Dead: Poland and the Memory of the Holocaust”, Syracuse University Press, Syracuse 1997, „Holocaust and Genocides Studies" 1997, nr 3, s. 427 (s. 426-443)]" (Melchior, 2000, s. 233).

„Autor zręcznie unika w swojej pracy wszelkich stwierdzeń, które mogłyby urazić jedną ze stron konfliktu" (Wóycicka, 2002, s. 178).

W moim odczuciu to, co recenzentki i recenzent podnosili jako największą zaletę książki, było równoznaczne z samounieważnieniem wywodu Steinlaufa. Z jednej strony bowiem Pamięć nieprzyswojona pokazuje, jak dalece w stosunku Polaków do Żydów nic nie było w porządku. Z drugiej zaś - w konkluzjach - przekonuje, że w gruncie rzeczy polska większość i polska kultura dominująca nie ponosiły za ten stan rzeczy odpowiedzialności. O czym tu zatem debatować? W efekcie, refleksji traumatycznej w polskiej humanistyce dotyczącej Zagłady mogły patronować nazwiska badaczy tyleż zasłużonych,

1 Wydanie amerykańskie: Steinlauf, 1997. W tekście odnoszę się do wydania polskiego: Steinlauf, 2001.

2 „Pojawia się pytanie, czy tezy w niej zawarte są dla polskiego czytelnika tak oczywiste, że nie wywołują dyskusji, czy też polskie społeczeństwo znużone debatą na temat Jedwabnego nie ma już ochoty zajmować się Zagładą i stosunkami polsko-żydowskimi podczas wojny i po jej zakończeniu" (Wóycicka, 2002, s. 175). 
co bezpiecznych z punktu widzenia polskiej kultury dominującej. Takich, którzy nie odnoszą się do polskiego kontekstu Zagłady i nie są zorientowani w specyfice lokalnych uwarunkowań.

Niekurtuazyjna lektura Pamięci nieprzyswojonej zakłada konfrontację przedstawionej w książce wiedzy z towarzyszącą jej interpretacją. W świetle rozwoju badań nad Zagładą w ostatnim dziesięcioleciu nie ostało się żadne z trzech twierdzeń przyjętych za wyjściowe założenia koncepcji polskiej pamięci Zagłady jako pamięci nieprzyswojonej. Obecne w niej szczeliny i pęknięcia stanowią zaczyn krytyki koncepcji polskiego doświadczenia Zagłady jako traumy. Jednakże książka Steinlaufa zasługuje na wnikliwą lekturę i debatę nie tylko z intencją rewizji i dekonstrukcji. Wywód autora zawiera bowiem również nurt sprzeczny z tytułową koncepcją. Nurt ten - podbudowany najnowszymi ustaleniami historiografii - odsłania swój poznawczy potencjał. Jako taki ma szanse zasilić prace nad nowym rozumieniem ram i treści polskich reakcji na Zagładę. Może również przyczynić się do bardziej realistycznej oceny konsekwencji owych reakcji dla kultury i społeczeństwa wojennej i powojennej Polski - ze szczególnym uwzględnieniem losu ofiar, wykluczonych z polskiej wspólnoty i polskiej opowieści.

\section{Pamięć nieprzyswojona. Rekonstrukcja}

Koncepcję doświadczenia Zagłady jako traumy wypracowano w latach siedemdziesiątych XX wieku w Stanach Zjednoczonych i Europie Zachodniej na podstawie badania świadectw, a także psychoanalizy i psychoterapii Żydów ocalałych z Zagłady - następnie również ich dzieci i wnuków³. Michael C. Steinlauf dokonał zatem istotnego przesunięcia dwojakiego rodzaju. Po pierwsze, ulokował namysł nad konsekwencjami Zagłady dla Polaków w polu „kultury posttraumatycznej”. Po drugie, założył strukturalną analogię między żydowskim a polskim doświadczeniem Zagłady. Analogia strukturalna nie oznacza podobieństwa ani - tym bardziej - tożsamości losów. Odwołując się do triady Hilberga (perpetrators - victims - bystanders), Steinlauf skonstruował swoją koncepcję w odniesieniu do Polaków zdefiniowanych jako świadkowie Zagłady. Usankcjonował w ten sposób spontaniczną praktykę translatorską, w myśl której bystanders to po polsku „po prostu” świadkowie ${ }^{4}$. Uczynił tak, nie bacząc na poznawczą problematyczność samej kategorii bystanders. Wspierając się obserwacją, że Zagłada - choć doświadczana

3 W wypadku drugiego i trzeciego pokolenia chodzi o transmisję obciążeń i konsekwencji traumy doznanej przez rodziców i dziadków (por. Spiegelman, 2010). Zjawisko opisywane jest jako „postpamięć” (Marianne Hirsch), „pamięć nieobecna” (Nadine Fresco), „pamięć dziurawa” (Henri Raczymow) czy „pamięć pamięci świadków”, która generuje „przeszłość zastępczą” (James E. Young). „Przekaz transgeneracyjny stanowi [...] osobny problem, zarówno psychiatryczny, jak i psychoterapeutyczny, historyczny, społeczny i kulturowy. Nasze człowieczeństwo i nasza kultura budują się poprzez przekazywanie z pokolenia na pokolenie pewnych wartości, zachowań, schematów, mitów i oczekiwań. A wraz z nimi - chcemy czy nie chcemy - przekazywana jest trauma. Dzieci osób ocalonych są bardzo silnie związane przekazem transgeneracyjnym z uczuciami i emocjami swoich rodziców, co wpływa na ich tożsamość. [...] Drugie pokolenie żyje zazwyczaj w atmosferze tajemnicy i niepewności, w poczuciu, że rodzice przeżyli coś, co trudno zrozumieć. Dlatego dzieci nie wiedzą, jak poruszać się w ich świecie, ale przejmują ich objawy, na przykład doznanie osamotnienia lub poczucie winy z powodu ocalenia" (Orwid, 2009, s. 122).

4 Ta popularna praktyka została zresztą uprawomocniona za sprawą publikacji polskiego przekładu pracy Hilberga pod tytułem Sprawcy, ofiary, świadkowie (Hilberg, 2007). 
z odmiennych pozycji i w odmienny sposób - dotyczyła w masowej skali obu grup, obok traumy ofiar założył istnienie traumy świadków.

Trauma nie jest kategorią wartościującą, lecz opisową. W strukturalnym rozumieniu to sytuacja głębokiego urazu, w której podmiot (także zbiorowy) nie jest w stanie przyswoić istotnej części własnego doświadczenia, tej o charakterze granicznym ${ }^{5}$. Przyswoić oznacza tutaj: uprzytomnić sobie, zrozumieć, wyciągnąć wnioski i wpisać w narrację tożsamościową, czyli opowieść o samym sobie. Przedmiot namysłu Steinlaufa stanowi „właśnie to, w jaki sposób Polacy opowiadają o własnej przeszłości” (Steinlauf, 2001, s. 7). Tytułowa „pamięć nieprzyswojona” to polska pamięć Zagłady widziana i opisywana jako pamięć traumatyczna. Na czym - według autora tej koncepcji - polega istota i zarazem specyfika polskiej traumy Zagłady? W jaki sposób badacz przedstawia jej genezę?

Zdaniem Steinlaufa, polska pamięć nieprzyswojona jest tworem wielowarstwowym, na który - prócz doświadczeń z okresu Zagłady - składają się także uwarunkowania wcześniejsze i późniejsze. Rozumowaniu badacza patronują cztery założenia. Po pierwsze, „zasadniczą polską reakcją w obliczu Zagłady była postawa biernego świadka” (Steinlauf, 2001, s. 9). Po drugie, przy całym zróżnicowaniu postaw i zachowań polska wina polegała na obojętności wobec losu Żydów. [Stosując klasyfikację Jaspersowską, w ujęciu Steinlaufa mielibyśmy do czynienia z winą niezarzucalną (por. Jaspers, 1979).] Po trzecie, wina obiektywna zamanifestowała się także w wymiarze subiektywnym, w postaci: „pokładów niemożliwego do zaakceptowania ani przezwyciężenia poczucia winy Polaków związanego ze świadkowaniem Zagładzie” (Steinlauf, 2001, s. 103). Po czwarte, polskie poczucie winy okazało się na tyle silnie uwewnętrznione i potężne, że przełożyło się na trwałe mechanizmy stłumienia oraz wyparcia w indywidualnym i zbiorowym wymiarze psychologicznym (por. Steinlauf, 2001, s. 103).

Steinlauf buduje koncepcję polskiego doświadczenia Zagłady jako traumy przez analogię z koncepcją Roberta Jaya Liftona, wyłożoną w pracy The Broken Connection: On Death and the Continuity of Life (1979). Przedmiotem badania Liftona były traumatyczne skutki masowego doświadczenia zagrożenia życia. Chodziło mu o zaburzenie lub wręcz zniszczenie struktury i spójności tożsamości. Wyszczególniał węzłowe problemy prześladujące osoby poddane tego typu długotrwałej presji: piętno śmierci, poczucie winy wobec śmierci, niemożność utożsamienia się z ofiarą, odrętwienie psychiczne, przymus powtarzania, zablokowanie procesu samoleczenia.

W uproszczeniu: przyjmuje się, że piętno śmierci oznacza gwałtowne stany lękowe związane ze śmiercią. Poczucie winy wobec śmierci odnosi się do sytuacji,

5 Trauma to „[z]darzenie w życiu podmiotu, które charakteryzuje pewna intensywność, niezdolność podmiotu do adekwatnej odpowiedzi na wstrząs i trwałe patogenne skutki w organizacji psychicznej" (Laplanche \& Pontialis, 1996, ss. 340-341). Po pierwsze zatem: chodzi tu o bodziec czy wydarzenie zewnętrzne. Po drugie zaś: o taki rodzaj zewnętrznego bodźca czy wydarzenia, które ma potencjał urazowy w świetle konstytucji podmiotu. Jako doświadczenie, które przydarza się podmiotowi, lecz nie zostaje włączone do jego świadomej osobowości, uraz psychiczny pozostaje poniekąd doświadczeniem niczyim (por. Caruth, 2010, ss. 111-123). 
„W której nie istnieje możliwość fizycznej czy nawet psychicznej reakcji. «Człowiek czuje się odpowiedzialny za to, czego nie zrobił, czego nie czut, a nade wszystko za rozdźwięk między tą fizyczną i psychiczną blokadą a tym, co jego zdaniem powinien był... zrobić i odczuwać. Istotą syndromu traumy [...] jest psychiczne odrętwienie». Termin ten określa reakcje, często mimowolne i nieświadome, które ograniczają zdolność odczuwania [...]. Mechanizm ten obejmuje zaprzeczenie, a także «niemożność utożsamienia się (widzę, że 'umierasz, ale nic mnie nie łączy z tobą ani twoją śmiercią)». Odrętwienie psychiczne odcina «ja» od «własnych źródeł zależnych od takich struktur psychicznych jak współczucie dla innych, zaangażowanie społeczne i inne wyższe wartości... [przez to, że] podważa najbardziej fundamentalne procesy psychologiczne... [...]». Odrętwieniu psychicznemu towarzyszy zazwyczaj gniew, wściekłość i agresja, poprzez które ofiary starają się odzyskać siły życiowe” (Steinlauf, 2001, s. 71).

Przymus powtarzania oznacza wysiłek dążenia do takiej przebudowy zranionej psychiki, której skutkiem będzie integracja traumatycznego doświadczenia. Zablokowanie procesu samoleczenia potrafi natomiast doprowadzić do sytuacji, w której straumatyzowana grupa stara się

„«przezwyciężyć traumatyczne doświadczenie zanurzenia w śmierci poprzez odtwarzanie go na swój sposób (na wzór przymusu powtarzania), zmieniając jednocześnie lub zamieniając uczestników tego doświadczenia, zawsze jednak w imię przetrwania własnego lub całej swojej grupy». Nieodłącznym elementem tego mechanizmu jest przemoc, tworzenie grupy [...] kozłów ofiarnych, dzięki której bierne dotąd ofiary mogą zamienić się w aktywnych prześladowców i nadal uważać się za ofiary" (Steinlauf, 2001, ss. 7-72).

Lifton analizuje sytuację w obrębie grupy ofiar. Steinlaufa interesuje relacja między grupą ofiar (Zagłady) a grupą zewnętrzną. (Rozróżnienie to wynika z faktu, że położenie Żydów i Polaków w świetle teorii i praktyki Zagłady było całkowicie różne. Nie oznacza ono ignorowania tego, co polszczyzna określa mianem polskiego cierpienia, i tych, których nazywa polskimi ofiarami wojny.) Badacz stara się uprawomocnić - upodstawować (sic!) zaproponowaną analogię bez analogii, przedstawiając modyfikacje niezbędne do zastosowania koncepcji Liftona do opisywanej przez siebie sytuacji.

Modyfikacja pierwsza odnosi się do poczucia winy. Zdaniem Steinlaufa zbiorowe polskie poczucie winy wiąże się z obecnością Polaków przy Zagładzie i wynika z dwóch czynników. Po pierwsze „z bezradności wobec hitlerowskiej machiny śmierci, co Lifton nazywa «poczuciem winy wobec śmierci»" (Steinlauf, 2001, s. 72). Po drugie, z antysemityzmu powszechnego przed wojną i w czasie wojny. Antysemityzm ów „z reguły” - pisze Steinlauf (por. Steinlauf, 2001, s. 72) - nie miał charakteru eksterminacyjnego, lecz eliminacyjny. Oznaczał powszechne pragnienie, „żeby Żydzi po prostu zniknęli”. Modyfikacja druga polega na uwzględnieniu korzyści ekonomicznych - zwanych dzisiaj eufemistycznie przewłaszczeniem i przewarstwieniem - jakie Zagłada przyniosła Polakom jeszcze w czasie wojny. Steinlauf konkluduje:

„Ani dla polskiego sklepikarza [...], ani dla tych Polaków, którzy przeprowadzili się do niegdyś żydowskich domów, biur, synagog i instytucji gminnych, korzystali z ziemi, fabryk, magazynów, pieniędzy, biżuterii, mebli, ubrań, naczyń i pościeli należących do Żydów, nie było

SLH 3/4 2014/2015 | str. 152 
rzeczą łatwą pod względem moralnym czy też psychologicznym zaakceptować ten nowy porządek. Nie lubić sąsiada, pragnąć, aby go nie było; potem obserwować jego niewiarygodną, całkowitą zagładę; wreszcie odziedziczyć [sic! - E.J.] to, co kiedyś do niego należało6: taka kolej wypadków może tylko niepomiernie wzmóc poczucie winy zrodzone przez samo traumatyczne przeżycie. Siła samooskarżenia jest tym bardziej destrukcyjna, że nie wiąże się ono z żadną rzeczywistą przewiną. [...] Ponieważ jednak Polacy jako świadkowie nie popełnili żadnej zbrodni, nie było czego odkupić - a przecież sam fakt bycia świadkiem Zagłady w powiązaniu z dotychczasową polską historią uruchomił psychologiczną i moralną pułapkę, z której nie było widać wyjścia. Poczucie winy nie do przyjęcia i nie do przezwyciężenia można było tylko odrzucić i stłumić, by w późniejszych czasach dawało o sobie znać w osobliwie zniekształconych formach" (Steinlauf, 2001, s. 73).

Wśród uwarunkowań polskiej traumy wcześniejszych niż Zagłada Steinlauf wskazuje zatem antysemityzm. Wśród uwarunkowań późniejszych natomiast - istnienie siły represyjnej, która nie dopuszczała do publicznej artykulacji urazu po Zagładzie, niezależnie od zahamowań oddolnych. Autorowi chodzi o powojenne władze i ich politykę historyczną:

„[...] zbiorowe dylematy psychologiczne i moralne, które wojna zaszczepiła w polskiej świadomości, problemy, które jak nigdzie indziej w powojennej Europie domagały się ujawnienia oraz długiej i nieuchronnie bolesnej publicznej analizy, były zamiast tego tłumione i nabrzmiewały w ukryciu" (Steinlauf, 2001, s. 12).

\section{Pamięć nieprzyswojona. Dekonstrukcja}

Przegląd założeń, które nie wytrzymały próby czasu, warto zacząć od najbardziej rozpowszechnionego spośród nich, a mianowicie od figury większości Polaków jako świadków - bezsilnych i bezradnych, biernych i obojętnych. W tym punkcie Michael C. Steinlauf wydaje się podzielać bez zastrzeżeń deklarację Jerzego Turowicza:

„Byliśmy bezsilnymi i bezradnymi świadkami zbrodni dokonywanej na naszej ziemi. Winą była jedynie obojętność znacznej części tego społeczeństwa wobec straszliwego losu Żydów” [Jerzy Turowicz, Auschwitz po 50 latach. Dlaczego dwa?, „Tygodnik Powszechny”, 5.02.1995, s. 10 (s. 1 i 10) - cyt. za: Steinlauf, 2001, s. 156].

Artykuł Turowicza pochodzi z 1995 roku, książka Steinlaufa z roku 1997. W roku 2013 w siedemdziesiątą rocznicę powstania w warszawskim getcie - odbyła się w Warszawie międzynarodowa konferencja Być świadkiem Zagłady ${ }^{7}$. Sesja otwierająca została zatytułowana Bezsilność, obojętność i milczenie świadków. Mimo upływu czasu, przyrostu wiedzy i rozwoju refleksji nad Zagładą paradygmat bezsilnego i w najgorszym razie obojętnego świadka trzyma się zatem mocno - niekiedy nawet, jak widać, w gronie ścisłych specjalistów.

6 Na temat tego, jak rzeczy miały się w istocie, por. Grabowski \& Libionka, 2014. Por. także krytyka zastosowania kategorii dziedzictwa i dziedziczenia w odniesieniu do własności zamordowanych i wypędzonych: Gross \& Grudzińska-Gross, 2011 oraz Matyjaszek, 2014/2015.

7 Konferencja Być świadkiem Zagłady. W 70. rocznicę powstania w warszawskim getcie (Warszawa, 22-23 kwietnia 2013); współorganizatorzy: Centrum Badań nad Zagładą Żydów, Instytut Pamięci Narodowej, Żydowski Instytut Historyczny im. Emanuela Ringelbluma. 
Bierność i obojętność. Inaczej niż głosi dominująca opowieść większościowa, bierność i obojętność nieżydowskiego otoczenia były jakościami niezwykle pożądanymi przez Żydów i zarazem tymi, których dojmująco zabrakło. Głównym problemem nie był zatem brak pomocy lub niedostateczna pomoc Żydom. Głównym problemem był niedostatek bierności i brak obojętności:

„Bynajmniej nie jestem zaślepiony, żeby uważać, że obowiązkiem każdego Polaka było z narażeniem własnego życia przechować u siebie w mieszkaniu Żyda, ale uważam, że obowiązkiem społeczeństwa polskiego było umożliwić Żydom swobodne poruszanie się po polskiej dzielnicy" (Perechodnik, 2004, s. 129).

Wielu Żydów byłoby w stanie poradzić sobie po „aryjskiej stronie” samodzielnie lub ze stosunkowo niewielkim i nieangażującym wsparciem, gdyby nie to, że niezwłocznie ktoś nimi zaczynał „się interesować”, używając języka epoki". „Interesowanie się” było równoznaczne z osaczaniem: utratą zdobytego punktu oparcia, koniecznością zmiany miejsca pobytu, powiększało ryzyko denuncjacji i śmierci (por. Głowiński, 1999):

„Powinni byli uratować się ci Żydzi, którzy z getta zdołali się wydostać, którzy otrzymali aryjskie dokumenty, którzy mieli gdzie mieszkać. [...] Dlaczego [Polacy - E.J.] nie byli dyskretni? Przecież niczego się już nie pragnie od nich jak tego milczenia, jak tego nieszeptania na ucho drugim [...], którzy dalej szeptali, aż wyszeptano o tym w gestapo. [...] Gdyby po prostu byli absolutnie bierni, uratowaliby się prawie wszyscy uciekinierzy z getta" ([Maria Nowakowska], Moja walka o życie, czyli wspomnienia Żydówki warszawskiej, AżıIH, pam. 142 cyt. za: Żbikowski, 2004, ss. 182-183)9.

Jeśli dodać do tego „powszechność zjawiska donosicielstwa i szmalcownictwa” (Żbikowski, 2004, s. 185), bierność i obojętność polskiej większości okazują się konstruktami pozbawionymi odpowiednika w rzeczywistości.

Użytkownicy kategorii obojętności traktują obojętność jak realnie istniejące zjawisko, lecz nie podejmują trudu wyjaśnienia jego genezy. Bo skąd nagle obojętność wobec Żydów w kulturze i społeczeństwie, gdzie stosunek do Żydów był rzeczą najmniej obojętną ze wszystkich, a lata Drugiej Rzeczypospolitej stanowiły intensywny antysemicki trening, w czasie którego raz po raz znikały ,jakiekolwiek inne [niż stosunek do Żydów - E.J.] linie podziału”, zaś „polskie antysemickie obsesje [...] sięgały psychozy, a w późnych latach trzydziestych wręcz obłędu, uniemożliwiającego jasne uświadomienie sobie niebezpieczeństwa wojny" (Miłosz, 1999, odpowiednio s. 522, 273)? Na mocy czego stosunek skrajnie nacechowany miałby przemienić się nagle w stosunek

8 Opowiadając o losach ukrywającej się Haliny Rogozińskiej, Zbigniew Dłubak systematycznie odwołuje się do tej właśnie kategorii. Rogozińską przechowywaną w piwnicy przez znajomych zaczęto „się interesować”, wobec czego zamieszkała u matki Dłubaka, ukryta w małym pokoiku, „ale dozorczyni zaczęła się interesować, kto to jest i co to za kuzynka. [...] Sytuacja zaczęła się robić bez wyjścia”. Po kolejnych perypetiach Rogozińska zgłosiła się do Arbeitsamtu. Tam znowu Polki oczekujące na wysłanie na roboty do Niemiec „zaczynały się interesować: «Czy ty nie jesteś przypadkiem Żydówką? Jak ty wyglądasz?!» Ale Niemcy nic. W ogóle” (Relacja Zbigniewa Dłubaka zarejestrowana przez Piotra Filipkowskiego w dniu 5 kwietnia 2003 roku w ramach międzynarodowego programu Mauthausen Survivors Documentation Project - sygnatura MSDP/156, nagranie z archiwum warszawskiego Domu Spotkań z Historią).

9 Jak podaje Żbikowski, świadectwo Nowakowskiej zostało opublikowane drukiem w 1948 roku z pominięciem cytowanych fragmentów. 
nienacechowany - i to w sytuacji, gdy w dziedzinach niebudzących porównywalnych namiętności dochodziło do eskalacji przemocy i rozprzężenia zwanego wojenną demoralizacją? Jedynym chyba, który próbował uprawdopodobnić nieprawdopodobieństwo, był Jan Błoński:

„Kiedy czyta się to, co o Żydach wypisywano przed wojną, kiedy się odkrywa, ile było w polskim społeczeństwie nienawiści - można się nieraz zdziwić, że za słowami nie poszły czyny. Ale nie poszły (albo szły rzadko). Bóg tę rękę zatrzymał" (Błoński, 1994, ss. 9-29).

Błoński proceduje metodą idem per idem: wyjaśnia tajemnicę tajemnicą. W jednym i drugim wypadku chodzi o tajemnicę wiary autora, której strukturę analizuje Tomasz Żukowski. Według Błońskiego doszło w Polsce do cudu.

„Cud ma jednak charakter retoryczny. Jak to bywa w literaturze, szczęśliwe rozwiązanie nie jest dziełem Pana Boga, ale autora, który konsekwentnie odwraca wzrok od tego, czego nie chce zobaczyć. [...] Błoński używa obrazu nawiązującego do Dziadów części III Mickiewicza. «Bóg tę rękę zatrzymał. Tak, Bóg, bo jeśli nie wzięliśmy udziału w tej zbrodni, to dlatego, że byliśmy jeszcze trochę chrześcijanami, że w ostatniej chwili pojęliśmy, jak szatańskie to było przedsięwzięcie...» [(Błoński, 1994, s. 23)]. Tak jak Konrad, który w ostatniej chwili, dzięki opiece Ducha z prawej strony i modlitwie przyjaciół powstrzymuje się przed bluźnierstwem, bezwiednie rozumiejąc, jak szatański bytby to krok. Staje na granicy ostatecznego upadku, ale jednak nie upada. Dzieje się coś empirycznie nieprawdopodobnego, ale w logice polskiego narodowego mitu wszystko się tłumaczy. Bo naród polski pozostaje pod szczególną opieką Bożej opatrzności i w istocie jest dobry. Sprawę winy związanej z Zagładą można skojarzyć z mesjanistycznymi strukturami rozumienia historii, w których Polska pozostaje niewinną ofiarą i Chrystusem narodów" (Żukowski, 2013, ss. 448-449) ${ }^{10}$.

Podjęta przez Błońskiego próba ugruntowania i uspójnienia odsłania nieugruntowany i niespójny charakter obojętności jako arbitralnego konstruktu. Nietrudno wywnioskować, że konstrukt ten przyjął się w polskiej narracji o Zagładzie nie z uwagi na adekwatność wobec stanu faktycznego, lecz z uwagi na wydajność z punktu widzenia naczelnej, wizerunkowej stawki tej narracji - stawki lokującej się na antypodach adekwatnego opisu.

Kategoria ta przyjęła się tak dalece, że - w sytuacji, gdy nie można zamknąć oczu na stan faktyczny w sposób zupełnie szczelny - w opisach stosunku Polaków do Żydów w okresie Zagłady bywa stosowane pojęcie obojętności życzliwej lub nieżyczliwej. Jest ono jawnym absurdem tak z punktu widzenia kontekstu historycznego, jak definicji słownikowych i elementarnej logiki ${ }^{11}$. Nazwanie nieobojętności wobec przemocy

10 Do cytowanego wywodu pragnęłabym dodać, że źródłowo - w judaizmie - ręką, którą zatrzymuje Bóg, jest ręka Abrahama, jednego z patriarchów-praojców Izraela, ludu przymierza. Figura powołana przez Błońskiego jest zatem, w moim odczuciu, silnie rywalizacyjna. Cofamy się tutaj do historii związania Izaaka z Księgi Rodzaju, pierwszej księgi Tory, a więc do samego początku: Bereszit. Wśród niewyartykułowanych założeń wypowiedzi Błońskiego można odnaleźć charakterystyczną dla antyżydowskiej teologii chrześcijaństwa doktrynę substytucji: Bóg troszczy się o nowy naród wybrany, a konkretnie o jakość jego życia, nie dbając o śmierć Izraela, który go zdradził. Było to myślenie nieodosobnione. Dwa lata po publikacji tekstu Błońskiego w recenzji książki Hanny Krall Sublokatorka można było przeczytać słowa: „Bóg nie zesłał Żydom aryjskiego Mesjasza. Bo myśmy [my, Polacy - E.J.] tej łaski nie wypłakali. I tu jest źródło naszego dzisiejszego dyskomfortu. Nasza niewinność nas oskarża" (Bieńkowski, 1989, s. II).

11 Terminu tego używano swobodnie w dyskusjach podczas wzmiankowanej już, międzynarodowej konferencji Byc świadkiem Zagłady. 
i wykluczenia obojętnością jest możliwe tylko w ramach kultury, w której przemoc i wykluczenie są przezroczyste jako część oczywistości społeczno-kulturowej.

Odrzucenie pojęcia obojętności jako fałszywej kategorii opisu postuluje Jan Tomasz Gross. Postulat ten uzasadnia jednakże odmiennie: „bystander w etymologicznym znaczeniu tego słowa w odniesieniu do Zagłady to oksymoron. Postawy «nic-nie-robienia», «nie-zainteresowania», «nie-zaangażowania» nie ma w ogóle w repertuarze zachowań dostępnych człowiekowi z powodu skali przemocy, jaką eksterminacja Żydów uruchomiła podczas Zagłady we wspólnie zajmowanej przestrzeni” (Gross, 2014, s. 886). Ze stwierdzeniem, że „nic-nie-robienie w obliczu Zagłady też jest działaniem” [podkreślenie - J.T.G.], można się tylko zgodzić. Zapytać jednakże należy, czy o nieobojętności rozstrzygała dopiero skrajna przemoc, czy też uprzednia definicja obiektu przemocy i czy nie mamy tutaj do czynienia z konfrontacją dwóch rodzajów nieobojętności. Żydzi w oczach większości byli zredukowani do antysemickiego fantazmatu. Krańcowo zdehumanizowani i - jak wyraziła się Maria Janion - „upluskwieni” w dwudziestoleciu międzywojennym, stali się - to znowu Janion - „zdatni do uśmiercenia” (por. Janion, 2000, ss. 136-147). Definicja obiektu przemocy pozwalała inaczej patrzeć na przemoc: racjonalizować ją, normalizować, legitymizować. Przemoc wobec Żydów była częścią normy kulturowej i tradycji chrześcijańskiej hołdującej doktrynie substytucji: zastąpienia judaizmu przez chrześcijaństwo, nie zaś harmonijnego wspótistnienia judaizmu z chrześcijaństwem. Nakładała się na to etniczno-religijna definicja wspólnoty. Przemoc wobec Żydów była praktykowana w Polsce przed wybuchem wojny i po jej wybuchu ${ }^{12}$. Antysemicką przemoc niemiecką - jako niemiecką właśnie - niejednokrotnie potępiano. Antysemicką przemoc polską marginalizowano, a jeśli przed nią przestrzegano, czyniono tak w trosce o zbawienie duszy i dobre imię narodu polskiego. Z pola widzenia znikała $w$ ten sposób sytuacja ofiar i widoczne $z$ ich punktu widzenia kontinuum antysemickiej przemocy. Z wnętrza paradygmatu przemocy i wykluczenia bardzo trudno było zobaczyć przemoc i wykluczenie jako problem zasadniczy. Problemem zasadniczym widocznym jasno i wyraźnie byli natomiast Żydzi. W tej perspektywie rozwiązania domagała się tak zwana kwestia żydowska, nie zaś kwestia przemocy wobec Żydów.

Bezsilność i bezradność. Bezsilność i bezradność również okazują się fikcją zbudowaną na fałszywym obrazie całkowitej izolacji Polaków od Żydów, poddanych Zagładzie niejako w próżni społecznej. W 2000 roku Jan Tomasz Gross zaproponował rekonfigurację spojrzenia na Zagładę:

„[...] o Zagładzie należy myśleć równocześnie na dwa sposoby. Z jednej strony trzeba ją umieć opowiedzieć jako system, który funkcjonował wedle z góry ułożonego (choć ulegającego ciągłym modyfikacjom) planu [a więc jako niemiecką hitlerowską zbrodnię państwo-

12 Zwracał na to uwagę Jan Karski w opisie zachowań i postaw Polaków wobec Żydów na samym początku okupacji: „Stosunek ich [Polaków - E.J.] do żydów [sic! - E.J.] jest przeważnie bezwzględny, często bezlitosny. Korzystają "w dużej części z uprawnień, jakie nowa sytuacja im daje. Wykorzystują wielokroć te uprawnienia, często nadużywając ich nawet. Zbliża ich to w pewnym stopniu do Niemców" (Karski, 2014, s. 29). Emigracyjny rząd polski skłonił, czy zmusit, Karskiego do ocenzurowania cytowanego raportu z przyczyn wizerunkowych, między innymi w tym właśnie punkcie. Przemoc antysemicką ukrywano, nie próbując jej przeciwdziałać. 
wą - E.J.]. Ale trzeba pamiętać, że była to również (a może przede wszystkim?) mozaika, na którą składały się oddzielne epizody, improwizacje lokalnych kacyków, a także niewymuszone odruchy i zachowania ze strony otoczenia" (Gross, 2000, s. 91).

Dzisiejsza periodyzacja Zagłady - proponowana m.in. przez badaczki i badaczy związanych z Centrum Badań nad Zagładą Żydów - obejmuje trzy fazy. Faza pierwsza to eksterminacja pośrednia, czyli gettoizacja. Polegała ona na przymusowym przesiedleniu do gett osób zakwalifikowanych jako Żydzi, co oznaczało dla nich pozbawienie podstaw utrzymania, postępującą degradację materialną, wysokie ryzyko śmierci z głodu, w wyniku pracy ponad siły i wskutek epidemii chorób zakaźnych. Faza druga to eksterminacja bezpośrednia metodą przemysłową, czyli w komorach gazowych (Akcja Reinhardt), choć szacuje się, że około półtora miliona Żydów straciło życie w masowych egzekucjach przez rozstrzelanie (Shoah par balles według określenia Patricka Desbois - ang. Shoah by bullets). Wreszcie faza trzecia: poszukiwanie przez ocalałych ratunku po „aryjskiej stronie”.

„Ten etap - nazywany przez Niemców Judenjagd, czyli «polowaniem na Żydów», miał dwie fazy: pierwszą [...], kiedy Niemcy (często przy pomocy policji pomocniczych) systematycznie wyłapywali ukrywających się [...], oraz drugą - trwającą praktycznie do końca wojny, polegającą na tropieniu, łapaniu i mordowaniu wszystkich ukrywających się jeszcze Żydów. W tej ostatniej fazie polowania Niemcy nie wyłapywali już Żydów sami - przyjeżdżali jedynie na wezwanie lub zabijali tych, których im mieszkańcy wsi i miasteczek dostarczyli na posterunek żandarmerii (w dużych miastach Żydów wydawali szmalcownicy i autorzy donosów zdradzający ich kryjówki) [...]" (Engelking, 2011, s. 25).

W procederze przemysłowej eksterminacji Żydów w drugiej fazie Zagłady Polacy nie mieli udziału.

„Można co prawda zastanawiać się, jaka była [...] rola polskiej policji granatowej czy też polskich junaków z Baudienst [a także jednostek Ochotniczej Straży Pożarnej - E.J.], ale jest jasne, że ich udział w likwidacji gett miał - z punktu widzenia Niemców - znaczenie raczej drugorzędne" (Grabowski, 2011, s. 169).

Problemem właściwym jest to, co działo się po „aryjskiej stronie”. Brak udziału Polaków w przemysłowej odsłonie zagłady Żydów nie oznaczał bowiem braku styczności z samymi Żydami. Styczność taka istniała we wszystkich trzech fazach Zagłady. W fazie pierwszej choćby z racji przepisywania własności, powierzania rzeczy na przechowanie, szmuglu żywności i wyprzedawania dobytku na niekorzystnych dla Żydów, prawie lub wręcz rabunkowych, zasadach. Tak zwanego przewłaszczenia, a konkretnie przywłaszczenia, które dla Żydów oznaczało wywłaszczenie, żadną miarą nie można nazwać dziedziczeniem, jak chce Steinlauf. Jan Tomasz Gross i Irena Grudzińska-Gross precyzują, że „zamordowanie albo wypędzenie człowieka nie daje nikomu tytułu własności do niczego, w tym również do pracy skumulowanej przez pokolenia w nagromadzonych przedmiotach, «pożydowska» może być tylko la façon de parler, a nie żadna własność" (Gross \& Grudzińska-Gross, 2011, s. 146).

Proces przewłaszczania/przywłaszczania/wywłaszczania - rozbierania do śmierci długo zresztą nie odnosił się do masy spadkowej po zmarłych, do której Polacy nie mieli

SLH 3/4 2014/2015 | str. 157 
żadnego tytułu ${ }^{13}$. Dotyczył żywych, którzy w drugiej fazie Zagłady w oczach większości zmieniali status na „jeszcze żywych”. Emanuel Ringelblum pisał w tym kontekście o postrzeganiu Żydów jako „nieboszczyków na urlopie”. Calel Perechodnik zaś - jako „żywych trupów”. Gross i Grudzińska-Gross natomiast określają status Żydów jako „tymczasowych depozytariuszy własności «pożydowskiej»” (Gross \& Grudzińska-Gross, 2011, s. 146).

Przesunięcie Żydów do kategorii liminalnej uruchamiało np. mechanizm obstawiania likwidowanych gett przez tłum w intencji rabunku albo mechanizm „gry na zwłokę"14 w wydawaniu Żydom zdeponowanych rzeczy. Nagminne było także okradanie uciekinierów z gett i transportów, równoznaczne z pozbawieniem ich możliwości ratunku, nawet wówczas, gdy kradzieży nie towarzyszyła denuncjacja. Zważywszy na reguły „przemysłu pomocy” (por. Grabowski, 2008) ${ }^{15}$, dostępnego dla Żydów pod warunkiem posiadania pieniędzy i ruchomego dobytku, praktyki tego typu były de facto grą większości na całkowitość Zagłady. „Przemysł pomocy” jako zjawisko społeczne to już trzecia faza Zagłady, gdy dystans operacyjny między Polakami a Żydami skrócił się niepomiernie albo wręcz zanikt:

„W trzeciej fazie Zagłady - po wysiedleniach, gdy wszystko stało się jasne i nikt nie miał już złudzeń - zmieniła się rola Polaków [...]. [...] Po głównej fali eksterminacyjnej [...] mieli realny wpływ na los poszczególnych Żydów. Ponieważ postępowanie Polaków często decydowało o życiu lub śmierci Żydów, kluczowa stała się ich rola z punktu widzenia ofiar" (Engelking, 2011, s. 132).

Z biegiem czasu i w miarę rozwoju wypadków Polacy zyskiwali nad Żydami władzę absolutną.

„[...] można dokonać typologii przestępstw na Żydach, w których uczestniczyli miejscowi Polacy. Najczęściej spotykaną formą współdziałania z Niemcami było uczestnictwo w obławach na Żydów organizowanych przez siły okupacyjne lub podejmowanych z własnej inicjatywy przez sformowane naprędce siły gorliwców, doprowadzanie napotkanych Żydów na posterunek policji i żandarmerii, znęcanie się nad Żydami w celu wymuszenia infor-

13 „W pierwszych miesiącach powojennych przywłaszczenie to, wcześniej odbywające się spontanicznie, znalazło swoją prawną regulację w postaci dekretu o majątkach opuszczonych i poniemieckich. Przywłaszczenie stało się w ten sposób podstawą nowego porządku przestrzennego dla miast, oraz nowego porządku społecznego dla ich mieszkańców, kształtując materialne zaplecze ich (naszych) wyborów i awansów. Po części z tego powodu nie mamy dziś jako społeczeństwo większego problemu z użyciem terminu «mienie pożydowskie» w codziennej mowie i praktyce życia. Jedyny rodzaj wątpliwości czy niepokoju, który towarzyszy użyciu tej codziennej struktury i stanowi ostatecznie o jej prowizorycznym charakterze, powodowany jest przez chybotliwą podstawę prawną tak uzyskanego majątku. [...] Mowa o Dekrecie z dnia 8 marca 1946 r. o majatkach opuszczonych i poniemieckich [Dziennik Ustaw 13, 1946, poz. 87, s. 165-172]. Według podanej w dokumencie definicji mienie opuszczone to «wszelki majątek (ruchomy i nieruchomy) osób, które w związku z wojną rozpoczętą 1 września 1939 r. utraciły jego posiadanie, a następnie go nie odzyskały». Jest nim też «majątek będący w posiadaniu osób trzecich na podstawie umowy zawartej z właścicielem [...], jeśli umowa ta miała na celu uchronienie tego majątku od utraty w związku z wojną lub okupacją». Na mocy dekretu majątek taki stawał się własnością skarbu państwa, z teoretyczną opcją zwrotu własności w trybie postępowania sądowego. Dekret ten nie był pierwszym aktem regulującym status prawny mienia pożydowskiego - jeszcze przez zakończeniem działań wojennych wydano Dekret $z$ dnia 2 marca 1945 r. o majątkach opuszczonych i porzuconych [Dziennik Ustaw 9, 1945, poz. 45, s. 55-59]" (Matyjaszek, 2013, ss. 130-131).

14 Sformułowanie użyte w tekście: Żukowski, 2010, s. 47.

15 Analizie mechanizmów i masowej skali zjawiska towarzyszy spostrzeżenie dotyczące niskiej skuteczności płatnej pomocy: „Pomoc ta była zazwyczaj krótkotrwała i bardzo złej próby” (Grabowski, 2008, s. 108). Por. także Berendt, 2008. 
macji o majątku, rabunki mienia, donosy ujawniające miejsce pobytu Żydów. Rzadsze były morderstwa na ukrywających się Żydach. Ofiarami tych ostatnich padali zarówno pojedynczy Żydzi, niezależnie od wieku i płci, jak i całe rodziny. Niekiedy zabijali ci, którzy Żydów ukrywali.

Uczestnikami tych zdarzeń są z jednej strony policjanci „granatowi”, członkowie Ochotniczych Straży Pożarnych, a wreszcie sołtysi. Wśród sprawców przestępstw nie brakuje też zwykłych mieszkańców wsi [...], także członków zbrojnych grup, w tym członków konspiracji zbrojnej. Na obszarach wiejskich, na których zamieszkiwali Żydzi, spirala zbrodni rozpoczynała się z chwilą wydania przez Niemców rozkazów koncentracji Żydów przed wysłaniem do obozów Zagłady. W niektórych przypadkach w działaniach tych [...] uczestniczyli wyłącznie Polacy, a Żydzi byli mordowani na miejscu" (Libionka, 2008b, ss. 150-151).

Uruchomił się też mechanizm społeczny, na mocy którego „Żydzi, traktowani jak «żywe trupy», rzeczywiście się nimi stają" (Żukowski, 2010, s. 47), a Zagłada działa jak samosprawdzająca się przepowiednia. Obok intensywnej przemysłowej produkcji trupów - a także po ogłoszeniu jej zakończenia przez Niemców - trwał ekstensywny, rozciągnięty w czasie, proces przerabiania „jeszcze żywych” na martwych przemysłem własnym, improwizowanym, domowym. Sukces eksterminacji oznaczał brak perspektywy powrotu do własnościowego status quo ante oraz, co nie mniej ważne, brak pokrzywdzonych. Dodać jednak należy, że nie chodziło tutaj wyłącznie o wymierne zyski. Całokształt operacji był opatrzony sankcją ideową - a właściwie: ideową i moralną - w postaci religijnej i „patriotycznej prawomocności uczuć antyżydowskich” (Smolar, 1986, s. 223). Teza o polskiej bezsilności i bezradności w obliczu Zagłady jest nie do utrzymania.

Świadkowie. W ślad za atrybutami takimi jak bierność i obojętność, bezsilność i bezradność, nie do utrzymania w odniesieniu do polskiej większości jest także kategoria świadka ${ }^{16}$. Podobnie nie do utrzymania jest kategoria bystanders.

„[W] języku polskim słowo bystanders nie ma dobrego ekwiwalentu. Tłumaczenie go jako «świadkowie» jest niewłaściwe. W języku angielskim istnieje słowo «świadek» i jest nim witness. Bystander to jedynie ktoś przypadkowo znajdujący się w pobliżu, który wcale świadkiem (tego, co się dzieje w pobliżu) być nie musi. Może nim być, ale nie musi. Znaczenie słowa bystander jest bardziej neutralne, obojętne w stosunku do tego, co się dzieje nieopodal. Bystander to równie dobrze osoba odwrócona tyłem, zajęta swoimi sprawami, jak i ktoś wspinający się na palce w tłumie gapiów" (Gross, 2014, s. 885).

Kategoria bystanders jako nieadekwatna do polskiego kontekstu więcej przesłania niż pozwala zobaczyć i zrozumieć. Dlatego należy odstąpić od niej na rzecz narzędzia bardziej precyzyjnego:

16 Lech Nijakowski na przykład używa wszystkich wymienionych pojęć, dzieląc świadków na obserwatorów bezpośrednich i obserwatorów niebezpośrednich (opinię publiczną). Do kategorii sprawców natomiast zalicza sprawców bezpośrednich i współsprawców. Pisze też „[...] dla skutecznej mobilizacji ludobójczej i samej akcji eksterminacyjnej kluczowe jest bierne przyzwolenie lub obojętność większości. Nie muszą oni aktywnie angażować się w ludobójstwo - wystarczy, że nie będą przeszkadzać bezpośrednim sprawcom" (Nijakowski, 2013, s. 86). Pojęcia te uchodzą zatem za nieproblematyczne kategorie opisu. Ich użyciu nie towarzyszy pytanie o sposób, w jaki zostały skonstruowane, co sugerują, co eksponują, a czego nie pozwalają zobaczyć. 
„Proponowałabym tu termin «obserwacja uczestnicząca wtajemniczona», bo sama «obserwacja uczestnicząca» to za mało. Byłaby ona dokonywana w trybie myśli, mowy, uczynku i zaniedbania. W tej kategorii - wydaje mi się - jest miejsce na mnogość i zniuansowanie przejawów. I być może otwiera ona także furtkę do zrozumienia, że tutaj chodziło o większość - zdecydowaną, a nade wszystko decydującą: o tym, że «cała Polska była gettem» [Karski, 1999, s. 15]" (Janicka, 2008, s. 238) ${ }^{17}$.

Na wszystkich trzech etapach Zagłady - przez całą okupację - Żydzi odbierali emitowane przez Polaków komunikaty: werbalne i pozawerbalne. Komunikaty te tworzyły kontinuum z większościowymi postawami i zachowaniami wobec Żydów przed wojną. We wszystkich obszarach życia postępowała wówczas antysemicka przemoc symboliczna: aryzacja. Na ulicach wzmagała się antysemicka przemoc fizyczna przy nagminnej bierności polskiej policji państwowej ${ }^{18}$. Debata publiczna była natomiast zdominowana nie przez zagrożenie wojenne, którego nie dostrzegano, czy zagadnienie reformy rolnej, której nie dokonano przez całe dwudziestolecie, lecz przez antysemityzm teoretyczny i praktyczny, osiągający rozmiary i rangę projektu eschatologicznego. Dopiero w tym kontekście można zrozumieć wiele zachowań ofiar, które bywają opisywane jako niezrozumiałe. Należą do nich rzekomo dobrowolne decyzje o udaniu się do getta, powroty do getta z kryjówek po „aryjskiej stronie”, podejmowanie ucieczki w zupełnej ostateczności lub niepodejmowanie ucieczki w ogóle - szczególnie wyraziście widoczne w wypadku polskich inteligentów dyscyplinowanych jako Żydzi przez czujne polskie oko egzekwujące to, co można określić mianem prawa spojrzenia (le droit de regard $^{19}$ ).

Za sprawą tego mechanizmu getto nie wymagało murów, czego przykładem Lwów i wiele innych miejscowości. Tam, gdzie istniały - jak w Warszawie - mury nie były i nie musiały być szczelne, skoro getto pozostawało aktualne również po „aryjskiej stronie". Getto było performatywem obowiązującym niezależnie od wyznaczników formalnych i terytorialnych delimitacji. Obserwator uczestniczący - na mocy przyjętej zasady wykluczenia - przywoływał wykluczonych do żydostwa, jak się przywołuje do porządku. Czynił to, ignorując tożsamościowe wybory i autoidentyfikację wykluczonych. Rozciągliwość przestrzenna była cechą nie tylko getta. Jeden z więźniów Treblinki, polski Żyd z Częstochowy, zwracając się do Żyda z Pragi czeskiej, opisuje „stronę aryjską” w wersji polskiej jako element mechanizmu ergo część przestrzeni Zagłady:

17 Por. Janicka, 2008, ss. 236-238, część Obserwacja uczestnicząca wtajemniczona - koniec triady Hilberga. Cytat wewnętrzny pochodzi z wypowiedzi Jana Karskiego: „Wejść do getta było bardzo łatwo, teraz się o tym nie wie. [...] Nie było tak trudno wyjść i wrócić. Trudno było Żydom z innych powodów. [...] Niech będzie, że Żyd uciekł z getta, no i co teraz? [...] Cała Warszawa była gettem. Cała Polska była gettem" (Karski, 1999, s. 15).

18 „Należy podkreślić grzeczne i uprzejme zachowanie się policji: była obecna, lecz zawsze przybywała za późno na miejsce wypadku, gdy szyby były wytłuczone, przedmioty zniszczone, a młodzież i w ogóle wybijacze szyb byli daleko, gotując się do nowej przeprawy. Niekiedy posuwała się tuż krok w krok za wybijaczami, lecz jakoś się działo, że nigdy na czas nie mogła się zjawić” (Krzywicki, 2009, s. 115). Dalej pisze Krzywicki o agresywnym potraktowaniu przez policję senator Władysławy Macieszyny i senatora Mojżesza Schorra, którzy usiłowali przeciwdziałać przemocy i zostali poturbowani przez uczestników zajść. Pisze również o cenzurze: „Wolno było szaleć rabacji sztubackiej, ale nie wolno o tym pisać" (Krzywicki, 2009, s. 115).

19 Por. niżej przyp. 33. 
"- Rysiek, chłopcze, ty nic nie wiesz - wy nic nie wiecie... [...] U nas Treblinka zaczyna się w gettach. I prawie wszyscy jakoś pomagają likwidować Żydów. Albo przynajmniej przytakują..." (Glazar, 2011, s. 71) ${ }^{20}$.

Inny ocalały z Treblinki mówił Racheli Auerbach:

"- To wciąż Treblinka.

- Treblinka jeszcze się nie skończyła. Prześladuje nas, jak nas prześladowała do teraz. W lesie, na strychach, w każdej dziurze, z której trzeba było uciekać z powodu najmniejszego nawet donosiciela. Teraz jest tu, na ulicy, w restauracji, gdzie przesiaduję ze swoim żydowskim nosem, choć powinienem od dawna już być na tamtym świecie" (Auerbach, 2012, s. 35).

Większościowe praktyki lokalnych społeczności nieżydowskich należy określić mianem „uzupełniania i uszczelniania hitlerowskiej machiny eksterminacji” (Janicka \& Żukowski, 2011, s. 20).

I nie chodzi tu jedynie o trzecią fazę Zagłady. Na wszystkich trzech etapach Zagłady obserwator uczestniczący wtajemniczony byłby tym samym obserwatorem uczestniczącym uszczelniającym. Jego obecność miałaby pośredni wpływ na liczbę ofiar od samego początku.

„Niekiedy pada pytanie: Dlaczegoście nie uciekli? Dokąd uciekać? Oni sobie nie wyobrażają tego... Nawet w dżungli można uciekać... może się to skończyć bardzo źle, ale jest jakaś droga, jakaś możliwość poruszania się, wyjścia z tej klatki. A getto to była klatka bez wyjścia - dokąd? Do kogo? [...] Dokoła tego muru był inny mur... Polacy nie powinni brać odpowiedzialności ogólnonarodowej za to, co było, ale w pewnym sensie - tak" (Engelking \& Gutman, 2013, s. 226).

W myśleniu na temat trzeciego ogniwa triady Hilberga zazwyczaj rozłącza się kategorie obserwacji i uczestnictwa. Tymczasem właśnie spojrzenie byłoby tu najbardziej podstawową formą działania, oddziaływania, sprawczości (ang. agency):

„Barbara Engelking: Czy był Pan kiedykolwiek po aryjskiej stronie?

Izrael Gutman: Nigdy. Nigdy nie spędziłem ani jednego dnia w ciągu tych lat. Przechodziłem tylko, idąc do pracy na placówkę. To był świat obcy, nie mój świat, do którego ja nie należę. I nie mogę należeć - nie mam żadnych szans [...]. Bo jak to było? Ci, którzy wychodzili z placówkami, chodzili w kolumnach. Jak wracali, zawsze było to samo: dzieci krzyczały, naśmiewano się z nich. Czy to wszystko był antysemityzm? Przecież to śmieszne. Ale oni tak to odczuwali, że jak wychodzą - ludzie tak się patrzą..." (Engelking \& Gutman, 2013, s. 227).

Autor tych słów Izrael Gutman uciekł z transportu do Treblinki, ponieważ istniało jeszcze wówczas w Warszawie getto, do którego mógł wrócić. Na temat uwięzienia na Majdanku, następnie zaś w Auschwitz I - już po powstaniu w getcie - mówił: „Nie miałem gdzie uciekać, dokąd uciekać, nie myślałem w ogóle o ucieczce” (Engel-

20 Autor przytoczonego komentarza, Dawid Brat, zginął w powstaniu więźniów Treblinki 2 sierpnia 1943 roku.

SLH 3/4 2014/2015 | str. 161 
king \& Gutman, 2013, s. 227) ${ }^{21}$. Dziś wiemy, jak dalece nie były to przypadki odosobnione.

Małgorzata Melchior, mimo iż nie odwołuje się do kategorii le droit de regard, rekonstruuje doświadczenie Żydów ukrywających się na widoku, czyli na „aryjskich papierach”, jako doświadczenie osób poddanych permanentnej władzy „aryjskiego” spojrzenia:

„«[A]ryjscy» Żydzi o swej przybranej tożsamości mówią najczęściej w kategoriach zaczerpniętych z języka teatru. [...] Metaforyka teatru odnosi się nie tylko do aktorów i odgrywanych przez nich ról, ale zakłada [...] także istnienie sceny i widowni. Sceną dla «aryjskich» Żydów był niemal cały obszar strony aryjskiej. Stawała się nią każda sytuacja, której uczestnikami były lub mogły być osoby, przed którymi nie należało ujawniać swego żydowskiego pochodzenia. Tym samym, osoby te stanowiły dla zagrożonych dekonspiracją widownię. [...] Mogły - intencjonalnie lub bezwiednie - obserwować i oceniać, czy dana postać jest autentyczna, czy nie ma w niej jakiejś sztuczności lub nienaturalności. Odgrywający swe role «aryjscy» Żydzi byli często świadomi, kto jest ich «widownią». [...] Od tego mogło zależeć ich życie" (Melchior, 2004, ss. 261-262).

Wielu z nich uprawiało camp avant la lettre (por. Janicka, 2011, s. 249, przypis 79). Rzecz jasna, ukrywanie się na „aryjskich papierach” było dostępne jedynie osobom „niepodobnym do Żyda" i panującym nad kodem kultury polskiej w stopniu doskonałym, choć to znowu narażało na demaskację z powodu wyczulenia jurorów na tak zwaną hiperpoprawność ${ }^{22}$. Zastosowana $w$ tym kontekście metafora teatru nie pozwala dostrzec i jasno zdać sprawy z faktycznej - sprawczej, rozstrzygającej - roli patrzących i oceniających. Uwaga ta odnosi się tak do analiz Małgorzaty Melchior, jak do koncepcji teatru jako matrycy Zagłady Grzegorza Niziołka (Niziołek, 2013). De facto bowiem patrzący i oceniający widzowie byli głównym rozgrywającym, tyle że z możliwością powołania się na alibi w postaci Niemców jako reżysera czy - jak wyraził się Calel Perechodnik „redaktora odpowiedzialnego”: „Niemcy, w razie czego wszystko i tak pójdzie na karb Niemców" (Perechodnik, 2004, s. 124).

Formułę Jana Karskiego - „Cała Polska była gettem” (w sensie śmiertelnej pułapki bez wyjścia) - można przetłumaczyć na obraz okupowanej Polski jako rzeczywistości panoptycznej. Rzeczywistość panoptyczna to urządzenie społeczno-kulturowe pozwalające „bez przerwy widzieć i natychmiast rozpoznawać” (Foucault, 2009, s. 195) zapewniające dotarcie do "najdrobniejszych i najbardziej peryferyjnych elementów”

21 „KK]ilku chłopakom z Treblinki i jeszcze skądś - udało się uciec. Wrócili do swoich gett i opowiedzieli wszystko. A dlaczego wrócili, skoro wiedzieli, że znowu ich stamtąd wywiozą na śmierć? [...] Bo chcieli nas ostrzec, a poza tym i tak nie mieli się już gdzie ukrywać. Wszyscy Polacy nienawidzą Niemców, ale na dziesięciu z nich dziewięciu nienawidzi też Żydów i bez ceregieli wydałoby ich [...]. Znam też przypadki, że ukrywali Żyda, przed północą wyłudzili od niego wszystkie pieniądze, a po północy poszli go zakapować niemieckiej żandarmerii i skasowali jeszcze nagrodę" (Glazar, 2011, s. 90).

22 „Otóż demonstrowała pochodzenie nie tylko zbytnia gestykulacja rękami, ale także nieustanne ruchy brwi i głowy. Poza tym decydowała polszczyzna bez akcentu i przepraszam, ale też nadmiernie wyszukana” (Jurandot, 2014 s. 447).

23 Jeżeli zamiast o zniewoleniu, pomyśleć o śmiertelnym zagrożeniu, do sytuacji Żydów po „aryjskiej stronie” można odnieść również fragment: „Pełne światło i spojrzenie nadzorcy zniewalają bardziej niż mrok, który ostatecznie osłaniał. Widzialność jest pułapką” (Foucault, 2009, s. 195). 
(Foucault, 2009, s. 210). Coś, co - niczym Foucaultowski kompletny aparat „wszechdyscyplinarny” - „nie ma zewnętrza ani luk, nie ustaje, póki całkowicie nie wypełni swego zadania" (Foucault, 2009, s. 228). Analizując panoptyzm, Foucault znajduje dla niego „historyczny odpowiednik albo przynajmniej punkt odniesienia” w obrębie „techniki «inkwizycyjnej»" (Foucault, 2009, s. 218). W procesie ewolucji procedury inkwizycyjnej w procedurę panoptyczną następowałaby jednakże zmiana przeznaczenia mechanizmu. „Kaźń była logicznym zamknięciem procedury, którą kierowała Inkwizycja”, podczas gdy ukoronowaniem panoptyzmu jest oddanie pod obserwację. W tym sensie - w polskim kontekście okupacyjnym - mielibyśmy do czynienia z połączeniem procedury panoptycznej ze zwieńczeniem charakterystycznym dla procedury inkwizycyjnej.

Rzeczywistość panoptyczna to „ogromna i mikroskopijna zarazem maszyneria” (Foucault, 2009, s. 216), „bezgranicznie zwarty splot procedur panoptycznych” (Foucault, 2009, s. 217). W polskim wydaniu - z punktu widzenia ofiar Zagłady - struktura ta opierałaby się na wszechobecnym i wszechwidzącym polskim nadzorcy, przypominającym rozproszone spojrzenie o wielu twarzach, „które przekształca całość ciała społecznego w pole percepcji: tysiące rozmieszczonych wszędzie oczu, ruchliwe i gotowe na zawotanie punkty obserwacyjne" (Foucault, 2009, s. 208) ${ }^{24}$. Nadzorca ów sprawowałby nieinstytucjonalną ${ }^{25}$, nieformalną, lecz faktyczną kontrolę społeczną nad przebiegiem Zagłady. Foucault czyni rozróżnienie między dyscypliną wyjątku, a dyscypliną-mechanizmem. Dyscyplina wyjątku to dyscyplina-blokada manifestująca się pod postacią zamkniętych instytucji w strefie społecznego marginesu. Dyscyplina-mechanizm to schemat ogólnego i uogólnionego nadzoru. Domeną getta (Niemców) byłaby dyscyplina-blokada (schemat dyscypliny wyjątku), zaś domeną „strony aryjskiej” (Polaków) - dyscyplina-mechanizm (schemat ogólnego i uogólnionego nadzoru) (por. Foucault, 2009, s. 204). Z tych modeli „[p]ierwszy jest marzeniem o nieskażonej wspólnocie, drugi - o zdyscyplinowanym społeczeństwie. [...] Schematy zatem odmienne, jednak dające się pogodzić. Widać, jak z wolna zmierzają ku sobie" - to pisze Foucault, rekonstruując genezę społeczeństwa dyscyplinarnego (Foucault, 2009, s. 194). W interesującym nas przypadku, dostrzegając odmienność schematów, nie byłabym pewna odmienności stojących za nimi marzeń. W każdym razie stało się tak, że Zagłada jako niemiecka nazistowska zbrodnia państwowa i lokalny kontekst społeczno-kulturowy weszły w relację sprzężenia, które należy określić mianem synergii: współdziałania czynników wzajemnie potęgujących swoją efektywność.

Literatura przedmiotu zazwyczaj rezerwuje miano „pomocników zbrodni” (auxiliaires des crimes) dla „pewnych przedstawicieli” (certains ressortissants) populacji chrześcijań-

24 Foucault pisze w tym miejscu o „spojrzeniu bez twarzy”, mając na myśli charakterystyczną dla panoptikonu niewidoczność nadzorcy. W interesującym nas przypadku mamy jednakże do czynienia z konfrontacją władzy absolutnej z absolutną niemocą. W związku z tym to, czy nadzorca jest widoczny, czy niewidoczny dla nadzorowanego - innymi słowy: czy spojrzenie nadzorcy ma twarz, czy nie ma twarzy - jest całkowicie przygodnym parametrem sytuacji.

25 Pisząc o „rojeniu się mechanizmów dyscyplinarnych”, Foucault używał terminu „dezinstytucjonalizacja” (por. Foucault, 2009, s. 205). W interesującym nas przypadku mamy jednak do czynienia z formą, a raczej mechanizmem czy strukturą, wyjściowo nieinstytucjonalną. 
skich, sytuując większość w roli „świadka mniej lub bardziej aktywnego lub pasywnego” (la figure du témoin plus ou moins actif ou passif) (por. Mink, 2010, s. 16). Tym samym z pola widzenia znika faktyczna rola większości. W analizie opartego na faktach opowiadania Zofii Nałkowskiej Przy torze kolejowym Aránzazu Calderón Puerta pokazuje, w jaki sposób Polacy - z pozoru nieagresywni i całkowicie bierni - zgromadzeni wokół rannej Żydówki pod nieobecność Niemców de facto, za sprawą samej swojej obecności, stają się jej mordercami. Egzekwują bowiem realizację antysemickiego scenariusza, który stanowi dla nich bezrefleksyjną oczywistość, a który dla Żydówki przewiduje jedynie śmierć. W ich obecności i oczekiwaniu - jak pisze Nałkowska - „Szło już tylko o to, aby tak czy inaczej umarła" (Nałkowska, 1982, s. 40):

„Miejscowi zbierający się wokół Żydówki uczestniczą w szczególnego rodzaju widowisku. Śmierć rannej jest w nim niekwestionowaną oczywistością. [...] Ludzie oglądają misterium losu. Śmierć Żyda jest w nim «częścią odwiecznego ładu Bożego na ziemi» [Bauman, 1994, s. 241]. Stosunek poszczególnych widzów do owego misterium może być różny - od satysfakcji przez obojętność do litości. Moc antysemickiego mitu polega jednak na paraliżującym działanie przekonaniu o nieuchronnym wyroku wpisanym w porządek świata. [...] Spektakl wyznacza role uczestnikom. Gapie zamieniają się w świadków losu, który dopełnia się na ich oczach. Oglądają potwierdzenie ich własnego przekonania [...]. Patrząc zyskują poczucie niewinności, bo przecież wyrok zapadł gdzieś indziej i należy do osnowy świata. Tymczasem w rzeczywistości przedstawionej przez Nałkowską to właśnie gromada patrzących dokonuje de facto egzekucji. Żydówkę zabijają wyobrażenia, które oddzielają ją od widzów i jednocześnie sprawiają, że wieś nie jest zdolna dostrzec własnego współudziału w zadawanej śmierci. Podział ról warunkowany antysemickim wzorem kultury [...] leży u podstaw rozpoznania wspólnoty jako świadków Zagłady. Rozpoznania, które w świetle relacji Nałkowskiej okazuje się fałszywe" (Calderón Puerta, 2010, ss. 145-147, rozdział Nieświadome działanie)26.

Aktualny stan badań pozwala orzec z całą pewnością, że kategoria świadka jest nieadekwatna do faktycznej pozycji zajmowanej w strukturze zbrodni przez chrześcijańską większość dominującą w obrębie czy na obrzeżach Zagłady - nie tylko zresztą w Polsce. Tymczasem wzmiankowana już konferencja Być świadkiem Zagłady (2013) - jeśli nie liczyć wystąpienia Jana Tomasza Grossa w końcowej dyskusji panelowej Co zostało z Hilbergowskiej triady „sprawcy - ofiary - świadkowie”? (por. Gross, 2014) - zupełnie nie odniosła się do tego problemu, mimo iż nominalnie jemu właśnie była poświęcona. Nie mówiąc o tym, że terminu „świadkowie” używano w jej toku zarówno w odniesieniu do żydowskich ocalałych, jak i członków chrześcijańskich populacji większościowych,

26 Cytat wewnętrzny z Zygmunta Baumana autorka przytacza za: Tokarska-Bakir, 2004, s. 36. Cytowanego sformułowania nie udało się odnaleźć pod podanym adresem bibliograficznym. Dwa szkice o moralności ponowoczesnej liczą 88 stron.

Na tym tle jako co najmniej połowiczne jawi się rozpoznanie Grzegorza Niziołka. Jego analiza dotyczy sytuacji typowej dla miasta, opisanej przez Kazimierza Brandysa w Samsonie: „Niewidzialność sprawców pozwala natomiast na różne sposoby «sakralizować» zdarzenie, wpisywać je w porządki konieczności, przeznaczenia, ludzkiej bezsilności wobec «sił wyższych». Matryca «tragedii» sama się nasuwa. «Sam Pan Bóg nie pomógł, a pani by chciała» - słyszy kobieta, która wyraża nieśmiała i słabą chęć udzielenia pomocy Jakubowi, a tym samym włączenia go we wspólnotę [...]” (Niziołek, 2013, ss. 48-49). „Niewidzialni sprawcy” to dla Niziołka Niemcy. Polacy to według niego „społeczeństwo bystanders” (por. Niziołek, 2013, ss. 33, 35). Niziołek nie widzi, że „niewidzialność sprawców” w opisywanym przez niego przypadku to niewidzialność rzekomych bystanders jako faktycznych sprawców - w ich własnych oczach. „Klarowną dystrybucję ról”, czyli ścisłe rozgraniczenie między niemieckimi perpetrators a polskimi bystanders, Niziołek uważa za „historycznie nieproblematyczne i etycznie słuszne”. Niesłusznie. 
nie przeprowadzając rozgraniczenia między perspektywą Primo Levy'ego a słownikiem Raula Hilberga. Debaty nie doczekały się terminy stosowane przez badaczy indywidualnie na własny użytek - niekiedy jedynie jednorazowo - lecz istotne w kontekście metarefleksji i badań podstawowych nad Zagładą. Mam tu na myśli figurę „asystenta zbrodni”, którą w jednym z tekstów posłużył się Jean-Charles Szurek ${ }^{27}$, i kategorię „uczestnika zbrodni” wysuniętą przez Tomasza Stryjka (por. Stryjek, 2011, s. 198). Myślę o „wcale nie niewinnym świadku”, o którym pisze Claudia Snochowska-Gonzalez, dodając, że „niepewny status Polaków jako świadków [...] każe przemyśleć kwestię sprawczości w historii oraz polskiej niewinności i/lub odpowiedzialności” (Snochowska-Gonzalez, 2013, s. 274). Myślę też o „pomocnikach śmierci: nieobrzezanych” z wiersza Miłosza Biedny chrześcijanin patrzy na getto. Myślę o propozycji zastąpienia kategorii „świadkowie” kategorią „obserwatorzy uczestniczący”, wysuniętej przeze mnie w roku 2008. Cytowana przez Grossa Mary Fulbrook zaproponowała kategorię „ułatwiaczy i beneficjentów” ( facilitators and beneficiaries) (por. Fulbrook, 2012 - cyt. za: Gross, 2014, s. 888).

Nie wspomniano wreszcie propozycji Tadeusza Markiela, bez której trudno wyobrazić sobie namysł nad aparaturą pojęciową w przedmiotowym zakresie. Rekonstruując jedno z polskich polowań na Żydów, które tradycyjnie skończyło się wydaniem Żydów Niemcom, Markiel nazywa Polaków zleceniodawcami zbrodni (por. Markiel, 2011, s. 88), Niemców zaś lokuje na pozycji zleceniobiorców. Autor celowo i świadomie zdecydował się na intelektualną prowokację, odwracając porządek sprawstwa i odpowiedzialności. Jednocześnie dokonana przez niego inwersja - w wymiarze doraźnym i subiektywnym, tak z punktu widzenia Polaków, jak i Żydów uczestniczących w opisywanej sytuacji okazuje się adekwatna względem stanu faktycznego. Andrzej Żbikowski natomiast opisuje Niemców mordujących Żydów na podstawie denuncjacji jako „pośredników” (por. Żbikowski, 2006, s. 229). Obie te konceptualizacje uzmysławiają, jak dalece pilna jest potrzeba położenia kresu stosowaniu kategorii świadka i uwspólnienia narzędzi terminologicznych przez badaczki i badaczy Zagłady.

\section{Kultura antysemicka?}

Wysuwając koncepcję polskiego doświadczenia Zagłady jako traumy, Michael C. Steinlauf stwierdza - a raczej może znowu zakłada - „niezdolność Polaków do przetworzenia doświadczenia [...] Zagłady, w przeciwieństwie do innych wspomnień narodowych, zwłaszcza tych z lat wojny, zgodnie z jakimkolwiek «jednoznacznym dychotomicznym modelem» moralności" (Steinlauf, 2001, s. 132). Badacz odwołuje się w tym miejscu do tekstu Andrzeja Bryka The Hidden Complex of the Polish Mind. Omawianego przez siebie fragmentu wypowiedzi Bryka nie stara się jednak uzgodnić z innym, cytowanym in extenso:

27 „Historiografia od 1945 do 1989 roku ukazywała sytuację binarną (niemiecki morderca, żydowska ofiara), która pozostawiała w cieniu figurę, również centralną, asystenta (tego, który asystuje)" (Szurek, 2010a, s. 104). 
„polskie społeczeństwo, wychowane w dużej mierze w antysemickiej kulturze i podświadomie traktujące Żydów jako obcych, [znalazło się - M.C.S.] nagle w sytuacji, kiedy kultura nie dawała już dostatecznego oparcia moralnego, aby przeciwstawić się łatwej akceptacji faktu zagłady Żydów przez Niemców" (Bryk, 1990, ss. 171-172 - cyt. za: Steinlauf, 2001, s. 132)28.

W polskiej opowieści większościowej antysemityzm chętnie bywa postrzegany nie tyle jako koherentny zbiór przejawów o czytelnej regule, ile chaotyczna zbieranina „incydentów”, które nie zakłócają w sposób zasadniczy nienajgorszych skądinąd stosunków między Polakami a Żydami. Za sprawą tej operacji mentalnej można następnie poszukiwać tak zwanych racjonalnych czy tak zwanych obiektywnych - to jest niezwiązanych z antysemityzmem - wytłumaczeń poszczególnych „incydentów”. Z tego punktu widzenia charakterystyczne jest, że w polszczyźnie przyjęło się określenie „eksces antysemicki”, nie przyjęło się natomiast określenie „antysemicka norma”. Normę nadal w większościowej opowieści wyobraża się bowiem jako nieantysemicką. Tymczasem z antysemicką normą mamy tutaj do czynienia. Normą przemocy i wykluczenia rozpisaną na wzory kultury większościowej, którą - za Andrzejem Brykiem - można nazwać kulturą antysemicką.

Maria Janion pisze o „antysemickim kodzie społecznym” i o tym, że miarę społecznej integracji stanowi w tym kontekście „odpowiednio afirmatywna reakcja” na ów kod (por. Janion, 2009a, s. 71). Dariusz Libionka operuje zaś kategorią „wpisanego w kulturę kodu antyżydowskiego" (por. Libionka, 2008b, s. 151). W kategorii kultury antysemickiej chodziłoby jednak o coś więcej w tym sensie, że antysemityzm nie stanowi jedynie jednego z nurtów czy kodów owej kultury, lecz jest generatorem tożsamości wspólnoty najpierw religijnej, następnie narodowej, ustanawianej według kryteriów etniczno-religijnych - będącej również wspólnotą aksjonormatywną.

„Pożytek z klasyfikacji - poczucie bezpieczeństwa wynikające z umocnienia poczucia tożsamości - odczuwany jest najsilniej właśnie wtedy, gdy wskazane zostanie uosobienie różnicy. W toku polskiej historii w tej funkcji zawsze występowali Żydzi, od średniowiecza organizatorzy polskiego systemu dystynkcji. [...] [P]olskie reklasyfikacje polityczne w wieku XX zawsze posługiwały się kluczem żydowskim (pierwsza wojna światowa, 1918, wojna roku 1920, sanacja, wkroczenie Rosjan, wkroczenie Niemców, powrót Rosjan, rządy komunistyczne, październik 1956, rok 1968 etc.), także i dziś nawet dalekie od antysemityzmu naprawcze hasła władz (np. walka z korupcją, tzw. nowa polityka historyczna), mylone są z innym, groźnym typem porządkowania, opartym na histerii tożsamościowej i nacjonalizmie" (Tokarska-Bakir, 2008, ss. 632, 634).

Konkluzja badaczki sytuuje się na przedłużeniu konkluzji Sandera L. Gilmana na temat powierzchowności rozróżnień między poszczególnymi stadiami i postaciami antysemickich uprzedzeń wobec trwałości ich struktury:

28 Tekst Bryka był głosem w debacie wokół polemiki między Janem Błońskim a Stanisławem Siła-Nowickim po publikacji tekstu Błońskiego Biedni Polacy patrzą na getto w „Tygodniku Powszechnym” w 1987 roku. Interesujące, że Steinlauf przedstawia Bryka jako człowieka „pochodzącego z rodziny kultywującej tradycje Armii Krajowej”, jak gdyby za pomocą tego certyfikatu poprawności tożsamościowo-przynależnościowej pragnął uwiarygodnić i uprawomocnić jego analizę (Steinlauf, 2001, s. 132). 
„periodyzacja postaw antysemickich jest przedsięwzięciem z gruntu fałszywym. Mówienie o chrześcijańskim antyjudaizmie, o antysemityzmie naukowym i ludowym oznacza jedynie badanie powierzchni retoryki, w którą oblekają się powszechne postawy wobec Innego. Śledząc ciągłość pojedynczego atrybutu przypisywanego Żydom, można dostrzec głęboką strukturę postaw wobec różnicy. Dlatego też ignorowałem etykiety wypracowane przez historyków antysemityzmu, opisujące taksonomię wyobrażeń antyżydowskich. [...] terminologia historyczna wydawała mi się czymś, co raczej zaciemnia, niż rozjaśnia wzorce, które odkryłem" (Gilman, 1990b, s. X - cyt. za: Tokarska-Bakir, 2008, s. 59: tłumaczenie fragmentu J.T.B. $)^{29}$.

W tym sensie nacjonalizm zreprodukował antysemickie struktury kultury chrześcijańskiej, dublując je i tym samym wzmacniając. Do religijnego dodał bowiem etniczne (a w gruncie rzeczy rasowe) kryterium wykluczenia. W polskiej kulturze dominującej był to moment, w którym figura Chrystusa zyskała sobowtóra w postaci Polski Chrystusa Narodów. Strukturalnie można by przyrównać antysemityzm do patriarchatu, obecnego - w sposób wypowiedziany lub niewypowiedziany - we wszystkich przejawach badanej kultury, wyjąwszy te, które problematyzują zjawisko i odżegnują się od niego w czytelny sposób w sferze mentalnej i emocjonalnej oraz na poziomie praktyk społecznych.

Analizując większościowe nastawienie do Żydów w Drugiej Rzeczypospolitej, Steinlauf formułuje zalecenie:

„W tym kontekście powinniśmy nawet unikać terminu «antysemityzm», ponieważ analizujemy w tej chwili uczucia, a nie ideologię, a ponadto z pewnością Polaków, którzy nie lubili Żydów, było znacznie więcej niż zdeklarowanych antysemitów" (Steinlauf, 2001, s. 72).

Autor nie podaje definicji antysemityzmu. Wydaje się jednak, że ma na myśli któryś z modeli typologicznych wypracowanych przez teoretyków lub historyków idei. Rygorystyczne zastosowanie przestrogi badacza w ostatecznej konsekwencji może prowadzić do wniosku, że antysemityzmu w Polsce nie było wcale bądź występował w ilościach śladowych. Potencjalnie zatem proponowane ujęcie likwiduje badany problem. Z ujęciem antysemityzmu jako ideologii przekonująco polemizuje tymczasem Shulamit Volkov:

„Funkcjonował on w podobny sposób na płaszczyźnie racjonalności i na płaszczyźnie wartości i norm implicite, stylu życia i myślenia, normalnych ambicji i emocji. Zbiór idei, uczuć i wzorców publicznych zachowań, typowy dla tego syndromu, nie daje się podporządkować hasłu „ideologii” w powszechnym rozumieniu tego pojęcia. O ile w ogóle zawiera ono w sobie systematyczną filozofię z bezpośrednimi wnioskami co do społecznego i politycznego działania, o tyle filozofia ta jest częścią większej całości. Światopogląd definiowałby to pojęcie tylko wtedy, gdy rozumieć go będziemy w szerokim znaczeniu. Lepszym terminem, Łatwiej kojarzonym z elementarnymi ludzkimi czynami i potrzebami, nie wyłączając całkowicie filozofii, nauki i sztuki, jest «kultura» - «całościowy splot wszystkich rodzajów

29 Badaczka nie do końca zgadza się z Gilmanem, argumentując, że „możliwe są nieantysemickie postaci antyjudaizmu. [...] [N]azywam je klasyfikacyjnymi, uznając, że bez tego rodzaju etykiet nie może się obejść żadna realistycznie pojmowana tożsamość" (Tokarska-Bakir, 2008, s. 60). Czy to możliwe w sytuacji dysproporcji pozycji obu grup względem siebie, to temat na osobną dyskusję. Pytanie dotyczy także asymetrii treści wyobrażeń (chrześcijańskie wyobrażenie żydowskiego bogobójstwa nie ma odpowiednika na gruncie judaizmu) oraz asymetrii ich statusu (wyznawcy judaizmu w oczach chrześcijan są obcym konstytutywnym, co nie działa w drugą stronę). 
myślenia, czucia i działania». Zarówno «ideologię», jak i «światopogląd» należy podporządkować pojęciu kultury, rozumianej jako «duża, symboliczna jedność», która jest przyswajana i rozdzielana przez jednostki i służy ich zjednoczeniu w «szczególnej i specyficznej wspólnocie»" (Volkov, 1995, ss. 16-17).

Jak w świadectwie Aleksandra Wata, który nie waha się użyć wielkiego kwantyfikatora, odmalowując antysemickie kontinuum wiekowe i klasowe - od nieuprzywilejowanych społecznie sześciolatków po dorosłych członków inteligenckiej elity:

„Andrzej [syn Watów - E.J.], który miał wtedy sześć lat, już to odczuwał. Chciałem koniecznie, żeby był w zwykłej szkole powszechnej, nie chciałem go oddawać do szkoły ekskluzywnej. [...] Ola go zaprowadziła pierwszego dnia. Andrzej nie miał rysów żydowskich, tylko kręcone włosy. Drzwi się za nim zamknęły, nauczycielka jeszcze nie weszła do klasy, ale Olę coś tknęło, uchyliła drzwi i widzi, że Andrzej stoi przysłonięty do ściany, a dokoła niego ta cała hałastra krzyczy: «Ty gudłaju» i chcą go bić! [...] Pełno było tego antysemityzmu i miatem to poczucie, które miał każdy Żyd, choćby najbardziej zasymilowany, tę absolutną pewność, że jak się odwrócić, to tam za plecami przyjaciele mówią: «Ten Żyd!»” (Wat \& Miłosz, 1990, s. 239) ${ }^{30}$.

Zwartą kategorię ideologii należy zatem zastąpić bardziej rozproszoną kategorią kultury ${ }^{31}$. Kategoria kultury - kultury antysemickiej? - przywraca przedmiot badania i pozwala ustanowić pole badawcze w oderwaniu od przyjętych przez Steinlaufa poprzeczek klasyfikacyjnych. Koncentrując się na praktykach społecznych, dopuszcza fragmentaryczność, zapętlenia, sprzeczności, współistnienie, nakładanie się na siebie i przepływy elementów różnych antysemickich wyobrażeń, mentalno-emocjonalnych struktur czy światopoglądów: na przykład antysemityzmu teologicznego i antysemityzmów tak zwanych ideologicznych.

Kultura antysemicka oznacza dystrybucję ról, zazwyczaj uchodzącą uwadze. Używając określenia „stosunki polsko-żydowskie” - które sugeruje partnerstwo i symetrię położenia obu grup - często tracimy z oczu, że odnosi się ono do relacji między większością a mniejszością, między dyskryminującymi a dyskryminowanymi, między wykluczającymi a wykluczanymi i ostatecznie wykluczonymi ${ }^{32}$. W perspektywie kultury antysemickiej antysemityzm traci status ekscesu i może zostać ujęty jako paradygmat, na który - prócz deklaracji i regulacji - składała się niezliczona ilość praktyk, które odzwierciedlały porządek społeczny i organizowały życie mniejszości oraz osób arbitralnie do niej zaliczonych jako grupy podporządkowanej i poddanej różnym formom przemocy w sposób ciągły.

W ramach kultury antysemickiej większości dominującej przysługuje prawo spojrzenia (le droit de regard) będące prawem oceny, karania i nagradzania oraz przywoływania

30 Andrzej Wat urodził się w 1931 roku. W przytoczonym fragmencie chodzi więc o rok 1937.

31 Szymon Rudnicki w podobnym znaczeniu używa kategorii mentalności, pisząc o obozie narodowym - endecji i ONR - który za sprawą rozłamów i delegalizacji ponosił przed wojną porażki organizacyjne, lecz nie ideowe. Wywierał bowiem skutecznie trwały wpływ na społeczeństwo i całość życia dalece nie tylko politycznego (por. Rudnicki, 1985, ss. 331-334).

32 Por. propozycja dekonstrukcji pojęcia: Melchior, 2013. 
do porządku społecznego ${ }^{33}$. Poziom zero (le degré zéro) ${ }^{34}$ władzy spojrzenia polegałby jednak na ustanawianiu, wytwarzaniu jej przedmiotu: „Żyda”

„dzięki redukcji - sprowadzeniu różnicy do tożsamości, wielości do jedności. [...] Wówczas Żydzi - ludzie jak wszyscy inni - zamieniają się w homogeniczną masę Żydów. Homogeniczna masa Żydów zaś - w «Żyda, co to pan wie, a ja rozumiem». «Żyd» to znak, którego desygnatem jest symboliczne i dosłowne wydrążenie z życia” (Janicka, 2001, s. 14).

Wytwarzanie „Żyda” oznacza przekształcenie jednostki w figurę gotową (ready made) o sztywnej trajektorii, obudowaną społeczno-kulturowym know how w postaci gotowego zestawu procedur postępowania. Konstrukt „Żyd” jest w stanie przetrwać każdą konfrontację z realnością. Jego konotacja ma radykalną przewagę nad denotacją. W razie doświadczeń osobistych zagrażających parametrom konstruktu kultura antysemicka pomaga zlikwidować dysonans poznawczy za sprawą wyobrażenia o żydowskim fałszu i związanego z nim esencjalizującego przeświadczenia, że Żyd zawsze pozostanie Żydem:

„«pojęcie Żyda w antysemityzmie nie ma nic wspólnego z Żydami» [Žižek, 2001, s. 65]. Istnieje rozziew między ideologiczną fi gurą Żyda a codziennym doświadczeniem np. wobcowaniu z rzeczywistym Żydem, który może być dobrym sąsiadem. Antysemityzm jako ideologia usuwa jednak tę sprzeczność, argumentując, że swą prawdziwą naturę Żydzi skrywają pod maską codzienności. W ten sposób zwycięża ideologiczny obraz Żyda. «ldeologia odnosi prawdziwy sukces dopiero wówczas, gdy fakty, które na pierwszy rzut oka jej przeczą, zaczynają funkcjonować jako argumenty przemawiające za nią» [ibidem, s. 67]. W ten sposób zostaje ocalona spójność ideologii, spójność obrazu świata" (Janion, 2009b, s. 107).

Stawką operacji jest konserwacja granic i władzy grupy dominującej oraz jej wyobrażeń o porządku społecznym i zarazem moralnym.

Powiedzieć, że „Żyd” to Inny lub Obcy, to nic nie powiedzieć. „Żyd” to emblemat rozległych połaci negatywności, wrogości i destrukcjij ${ }^{35}$. (Nawet pozytywne zdolności czy moce, jakie przypisywano „Żydowi” w światopoglądzie tak zwanym archaicznym, wynikały z jego związków z siłą nieczystą, Diabłem [por. Trachtenberg, 1997].) Tak zwane zabobonne przekonania i praktyki „ciemnego ludu” miały w tym zakresie charakter wtórny, świeciły światłem odbitym. Były pochodną ramowego paradygmatu kultury ufundowanego na elitarnych, teologicznych, następnie zaś również ideologicznych, uzasadnieniach. W kulturze antysemickiej słowo „Żyd” tłumaczy się samo przez się. „Żyd” to

33 Termin ustanowiony przez Michela Foucaulta, rozwinięty przez Pierre’a Bourdieu. Spojrzenie według Bourdieu jest jednym z głównych narzędzi władzy symbolicznej o doniosłych praktycznych konsekwencjach. Chodzi o władzę, „której skuteczność zależy od względnej pozycji patrzącego, pozycji tego, który jest obiektem spojrzenia, i od stopnia, w jakim wykorzystywane schematy postrzegania i oceny są znane i uznane przez tego, wobec którego się ich używa" (Bourdieu, 2004, s. 81). Stąd konieczność dyscyplinowania tych, którzy, kwestionując bezalternatywność porządku społecznego, ujawniają zarazem jego arbitralność. Spojrzenie jako formę władzy - na przykładzie male gaze, czyli męskiego spojrzenia uprzedmiotawiającego kobietę - opisała Laura Mulvey (por. Mulvey, 1975).

34 Chodziłoby tu o sens źródłowy pojęcia „stopień zero” (le degré zéro), które pochodzi z teorii językoznawczej Viggo Brondala: „W fonologii funkcją fonemu zero miałoby być przeciwstawienie się nieobecności fonemu” (Barthes, 2009, s. 13, przypis tłumaczki).

35 Jako dziecko żywiłam przekonanie, że słowo „pasożyt” pisze się przez „d” na końcu, a w liczbie mnogiej brzmi ono „pasożydy”. Moje przeświadczenie pochodziło „z powietrza”. Mowa tu bowiem o Polsce lat siedemdziesiątych XX wieku, gdzie o Żydach nie mówiło się, jeśli nie liczyć antysemickiego konglomeratu: zasłyszanych tu i ówdzie strzępów wspomnień, dowcipów i katechezy. Na temat stosowanej przez Calela Perechodnika kategorii „l'air du pays” jako ekwiwalentu kategorii „kultura” por. Żukowski, 2010, s. 48 
„Żyd”. „Po prostu”. Wszystkie dookreślenia są niedostateczne i w gruncie rzeczy zbędne. Dlatego też w epoce przednowoczesnej, a i w dobie nowoczesności - także przed wojną, w czasie wojny oraz po wojnie:

„[w]ystarczyło [...] krzyknąć «Żyd!», by nastąpiła eksplozja i by wszystkie emocje wydostały się na powierzchnię" (Tokarska-Bakir, 2004, s. 67).

Widać to w napisach pokrywających mury miast i miasteczek dzisiejszej Polski, gdzie słowo „Żyd” starcza za całe uzasadnienie deklaracji nienawiści kierowanych do rozmaitych adresatów, samo już zresztą będąc taką deklaracją.

Porządek społeczny jest zarazem porządkiem moralnym (Bourdieu, 2004, s. 105). Mur getta można nazwać wizualizacją porządku moralnego właściwego kulturze antysemickiej. Getta i mury zmaterializowały się w Polsce wskutek niemieckich rozporządzeń. Jednakże getta dla Żydów domagano się w przedwojennej Polsce expressis verbis od lat dwudziestych i wprowadzano je w życie w miarę możliwości w rozproszonych formach symbolicznych, niemniej z praktycznymi konsekwencjami: na przykład pod postacią bojkotu ekonomicznego, niedopuszczania do służby w administracji i wojsku, paragrafów aryjskich w stowarzyszeniach zawodowych, kolejnych odsłon „afery trupiej” czy getta ławkowego uchwalonego przez senaty wyższych uczelni całkowicie legalnie, na mocy rozporządzenia ministra wyznań religijnych i oświecenia publicznego w 1937 roku (Natkowska, 1999). Szkoły „czyszczono” z nauczycieli uznanych za Żydów, choćby byli Polakami wyznania rzymskokatolickiego ${ }^{36}$. Selekcję prowadzono w harcerstwie ${ }^{37}$. W miasteczkach przestrzegano podziału chodników: na te dla chrześcijan i te dla Żydów ${ }^{38}$. Logika segregacji rasowej stawała się coraz bardziej ofensywna i widoczna. Rok przed wojną na ulicach Drugiej Rzeczypospolitej pojawił się plakat z hasłem „Żydzi do ghetta!". Na obrazku przewiązana biało-czerwoną wstęgą miotła zamaszyście i hurtowo wymiatała: brodate postaci w chałatach, kapitalistę w cylindrze Wuja Sama, komunistę z czerwonym sztandarem, sylwetki wielkomiejskich inteligentów, opatrując te - różnorodne na pierwszy rzut oka - śmieci wspólnym mianownikiem. Objaśnienie na plakacie głosiło: „ «GHETTO» - to zamknięty teren, gdzie Żydom wolno żyć i zarobkować. Dopóki Żydów całkowicie z Polski nie usuniemy, trzeba im we wszystkich dziedzinach życia

36 Chodziło o konwertytów i potomków konwertytów, którzy w oczach większości nadal pozostawali Żydami. Z elitarnego gimnazjum i liceum im. Stefana Batorego w Warszawie usunięto nauczyciela propedeutyki filozofii Adama Zieleńczyka i historyka Józefa Targowskiego. Adam Zieleńczyk, wuj Krzysztofa Kamila Baczyńskiego, zginął wraz z rodziną w sierpniu 1943 roku w Warszawie po „aryjskiej stronie” wskutek denuncjacji. Por. także Jedlicki, 2013, s. 22

37 Por. eufemistyczno-eliptyczny fragment na temat „porządków” w legendarnej 23 WDH im. Bolesława Chrobrego: Zawadzka \& Rossman, 1991, s. 33. „Należałem do harcerstwa, ale do harcerstwa żydowskiego, ponieważ Żydów nie przyjmowano wtedy do ZHP. To było afiliowane przy ZHP, posługujące się statutem ZHP harcerstwo o charakterze piłsudczykowskim. Tam dawali swoje dzieci na ogół legioniści Żydzi, których było dużo, zwolennicy Piłsudskiego, ci którzy nie byli ani ortodoksyjnie religijni, ani nie sprzyjali syjonistom, ani skrajnej lewicy. [pytanie: Czy były wspólne obozy, czy były kontakty z ZHP?] Były kontakty, ale na wysokim szczeblu. Normalnie nie było żadnych. Mieliśmy wszystko to samo, te same stopnie, te same sprawności harcerskie, tyle że nie nosiliśmy krzyży, tylko lilijki z małą Gwiazdą Dawida" (Relacja Zbigniewa Grabowskiego z 6 czerwca 2007 roku dla Archiwum Historii Mówionej Muzeum Powstania Warszawskiego; Brama \& Grabowski, 2007). Sprawy te są całkowicie nieobecne w horyzoncie badawczym historyków harcerstwa.

38 Po raz pierwszy o tej praktyce dowiedziałam się w latach siedemdziesiątych XX wieku z opowieści osób pamiętających przedwojenny Kalisz. O przedwojennym apartheidzie chodnikowym mówi także kielecki fotograf w filmie Świadkowie (1987) Marcela Łozińskiego. 
polskiego wyznaczyć «GHETTO»!"39. Plakat apelował do zdroworozsądkowego przekonania, że miejsce śmieci jest na śmietniku, a porządek musi być. Słyszalnych protestów nie było.

Getto jako fakt społeczny - czy jako praktyka społeczna - w kulturze polskiej nigdy nie przestało istnieć, o czym świadczą losy tych, którzy uwierzyli w możliwość osiągnięcia równych praw na mocy kontraktu akulturacyjnego czy asymilacyjnego. Wiele i wielu z nich było gotowych zapłacić cenę samowyrzeczenia i samoponiżenia liczoną według stawek, jakich nie żądano od ludzi uważanych za członków którejkolwiek innej grupy. Górną granicą możliwą do osiągnięcia okazał się jednak status tolerowany (niem. Duldung), warunkowy, wymagający ustawicznego podtrzymywania i potwierdzania przez zapewnianie o własnej lojalności i prawomyślności metodą przyświadczania większościowej opowieści. Najdrobniejsze posądzenie o nielojalność czy nieprawomyślność katapultowało niesubordynowanych poza ramy wspólnotowe, gdzie w gruncie rzeczy cały czas - tyle że w zawieszeniu - widziano ich miejsce. „Warunkowe przyzwolenie na wspólnotę jest nieustannym egzaminem z podporządkowania" (Żukowski, 2010, s. 50) ${ }^{40}$. Nadrzędną ramą dla kontraktu asymilacyjnego była bowiem rama kultury antysemickiej.

Co dopiero powiedzieć o położeniu tych, którzy nie podejmowali starań o asymilację? Kultura obywatelska - w ramach której mogliby istnieć na równych prawach - była powierzchowna i wątła. Obecna w deklaracjach, realizowała się w odosobnionych epizodach. Nieugruntowana w systemie społecznych wyobrażeń i praktyk, była otwarcie i zażarcie zwalczana przez Kościół i endecję, roszczące sobie prawo do wyłącznego definiowania i reprezentowania tak zwanej polskości. Pytanie o sens ulokowania polskości na szczycie wspólnotowej hierarchii wartości nie wchodziło w grę dla nikogo pragnącego zaliczać się do wspólnoty. Pytali o to jedynie komuniści kwestionujący status quo i z tego tytułu postrzegani jako obcy, wrogowie, fantazmatyczne żydowskie pachołki lub po prostu jako Żydzi. W ten sposób domykało się błędne koło i zarazem pułapka antysemityzmu i ksenofobii.

\section{Kultura antysemicka a Zagłada}

Rozumowanie wysuwające koncepcję polskiego doświadczenia Zagłady jako traumy zbiorowej pochodzi z wnętrza kultury i wrażliwości, które zagładę Żydów postrzegają jako niewyobrażalną, niemożliwą do powetowania stratę i bezprecedensowe, jednoznaczne zło. Maria Orwid w następujący sposób rekonstruuje genezę takiego ujęcia sprawy:

39 Na egzemplarzu przechowywanym w Żydowskim Instytucie Historycznym widnieje dodatkowo pieczątka: „Chcesz wypędzić żydów [sic!] głosuj na Obóz Narodowy” (por. reprodukcja plakatu: Janicka, 2011, s. 363).

40 Z punktu widzenia komunikacji społecznej i praktyk dyskursywnych wygląda to tak: Żyd „uczestniczy w grach, które nieustannie przypominają, że jest napiętnowany i że wykluczenie związane z piętnem żydostwa pozostaje normą zawieszoną tylko na chwilę, w drodze wyjątku. Wyjątku, będącego rodzajem próby. Żyd czuje na sobie wzrok polskich rozmówców, sprawdzających, czy dostosowuje się do reguł rytuału. [...] Nie wolno mu mówić własnym głosem ani wyrazić tego, co przeżywa. Ma pozostać doskonałym potwierdzeniem obrazu, który wytworzyła na jego i na swój własny temat grupa dominująca" (Żukowski, 2010, s. 50). 
„Rolę świadk a zaczęto dostrzegać i analizować dopiero w latach osiemdziesiątych ubiegłego wieku. [...] Uznano więc, że świadek jest również postacią straumatyzowaną, ponieważ oglądanie największej zbrodni w dziejach musiało pozostawić ślady w umyśle i sercu takiego człowieka" (Orwid, 2009, s. 93).

Analiza wypowiedzi Marii Orwid, a także Michaela C. Steinlaufa, ujawnia arbitralny i aprioryczny charakter koncepcji pozbawionej ugruntowania w empirii, nieopartej na psychoanalitycznym czy psychoterapeutycznym - ani żadnym innym - rozpoznaniu sytuacji i doświadczenia domniemanego świadka. Stąd brak w jej obrębie analizy i krytyki kategorii świadka. Brak również przypuszczenia, że mogą istnieć standardy percepcji i wartościowania inne niż właściwe badaczom i wyraźnie uważane przez nich za oczywistość ${ }^{41}$. Mamy tu do czynienia z mechanicznym niemalże przeniesieniem schematu reakcji traumatycznej z grupy ofiar na grupę zewnętrzną. Mimo adaptacyjnych komentarzy zabieg ten nie daje się uprawomocnić w świetle wiedzy, którą dysponujemy. Trauma świadka - podobnie jak sam świadek - stanowi zmistyfikowaną kategorię opisu. Blokuje procesy wyjaśniania i próby rozumienia.

W tym miejscu celowe wydaje się odwołanie do, poczynionego przez Kennetha L. Pike’a, rozróżnienia na emic i etic, oznaczającego dwa modele analizy:

„Model emiczny (od słowa: phonemic) polega na wyjaśnianiu zjawisk badanej kultury w terminach z niej się wywodzących. Model etyczny (od słowa: phonetic) opiera się na kategoriach zewnętrznych wobec badanej kultury, na przykład tych, których dostarcza naukowa siatka pojęciowa. Pierwszy uwzględnia specyfikę danej kultury, drugi aspiruje do uniwersalności. Wnikliwa analiza danych [...] z zastosowaniem podziału na dwie siatki pojęciowe: wewnętrzną, pochodzącą z badanej kultury, i zewnętrzną, pochodzącą z języka badawczego, pozwalają dokonać przekładu kulturowego. Stosowane oddzielnie, modele te prowadzą badaczy w rozmaite pułapki. Niebezpieczeństwem pierwszego jest traktowanie słownika emicznego jako dosłownej rekonstrukcji analizowanego świata, niezapośredniczonej językiem i wartościowaniem badacza. [...] [Natomiast] [k]ategorie etyczne, zastosowane bezrefleksyjnie, prowadzą do narzucenia własnego systemu klasyfikowania (deskryptywnego i wartościującego) na opisywaną kulturę [...]. [...] Nie biorąc pod uwagę kontekstu [...], posługiwanie się wyłącznie kategoriami etycznymi ma charakter skolonizowania przedmiotu badań i pozbawienia go głosu [...]" (Zawadzka, 2009, s. 213) ${ }^{42}$.

W namyśle nad polskim doświadczeniem Zagłady perspektywa emiczna wydaje się niejednokrotnie co najmniej niedowartościowana. Michael C. Steinlauf na przykład w wielu miejscach odnotowuje jej istnienie, lecz odnośne fragmenty swojej pracy pozostawia bez syntetyzującej konkluzji:

„To przecież Polacy widzieli, jak rosną mury getta i widzieli uwięzionych za nimi swoich sąsiadów. Polacy widzieli płonące getto, mogli widzieć swoich sąsiadów stłoczonych w zaplombowanych wagonach, jadących na miejsce przeznaczenia, czuli zapach dymu z krematoriów, byli świadkami polowań na uciekinierów. Indywidualne spostrzeżenia potwierdzały

41 Przyjęcie danego założenia, wyobrażenia czy odczucia za oczywistość sprawia, że oparte na nim sądy wartościujące traktowane są jako opisowe, a dokonywane na jego podstawie operacje uchodzą za nienacechowane.

42 W ujęciu Pike’a „słowo etyczny [...] w żadnym razie nie oznacza badania moralności i filozoficznego wyprowadzania zasad moralnych" (Zawadzka, 2009, s. 213, przypis 22). 
relacje rodziny i przyjaciół oraz podziemnej prasy. Polacy powinni być w stanie bez trudu wywnioskować, że są świadkami próby wymordowania wszystkich Żydów w Polsce, a może nawet wszystkich w Europie" (Steinlauf, 2001, s. 67).

Nawet na prawach hipotezy badacz nie dopuszcza, że Polacy to właśnie wywnioskowali i z wniosku tego wyciągali dalsze konsekwencje - na przykład w postaci gry na całkowitość Zagłady. Podobnie nieprzystawalność badanego materiału do zaproponowanej ramy interpretacyjnej nie wpływa na modyfikację wyjściowych założeń jego rozumowania.

„[P]owstała ciągłość w negatywnym stereotypie Żyda: tak samo przed, podczas, jak i po wojnie przedstawiano go jako szkodnika, mściciela, wroga wszystkiego, co polskie. Ta widoczna trwałość stereotypu nasuwa jednak oczywiste pytanie: jak zdołał on przetrwać Zagładę? Jak można było zobaczyć na własne oczy Zagładę i nie zmienić konwencjonalnego nastawienia do Żydów? [...] Dokonująca się na oczach Polaków zagłada narodu żydowskiego zdaje się w niczym nie zmieniać zakodowanego w zbiorowej wyobraźni stereotypu Żydów jako zagrożenia..." (Steinlauf, 2001, ss. 67-68)

Badacz powołuje się w tym miejscu na autorytet Krystyny Kersten, która afirmację Polski bez Żydów w kręgach polskiej elity konspiracyjnej opisuje jako zjawisko oparte na zbiorowym nieporozumieniu, braku wglądu w rzeczywistość, nienadające się do pojęcia w racjonalnych kategoriach przyczyny i skutku:

„Między skutkiem - Polską bez Żydów, a przyczyną - zbrodnią nie mającą precedensu, tak ogromną, że nie dającą się wręcz ogarnąć wyobraźnią [...], został zerwany związek (Kersten, 1992, s. 23, cyt. za: Steinlauf, 2001, s. 68).

Zerwany związek. The Broken Connection. Koncepcja nieprzyswojenia umożliwia Steinlaufowi pozostanie w wymiarze etic i utrzymanie statusu własnego światopoglądu jako powszechnie obowiązującego. Aprioryczne założenie, że mamy do czynienia z tajemniczą i w gruncie rzeczy niespójną łamigłówką, chroni go przed dostrzeżeniem w analizowanym materiale jak najbardziej koherentnego i konsekwentnego wzoru. Tymczasem w perspektywie emic - widziane z wnętrza kultury antysemickiej - te same elementy układają się w zgoła inny obraz.

Andrzej Bryk stwierdzał, że kultura antysemicka nie dawała „dostatecznego oparcia moralnego, aby przeciwstawić się łatwej akceptacji faktu zagłady Żydów przez Niemców”. Według rozpoznania Aliny Całej - wnoszonego ze świadomością skali zbrodni na Żydach na marginesach Zagłady - „zakodowane w kulturze odruchy, przeniesione w nowe warunki wojenne, stały się przyczyną zbrodni, których ocenić nie mogło sumienie wychowane w tradycyjnej agresywności” (Cała, 2005, s. 175). W tej sytuacji należy zapytać, czy kultura antysemicka nie spełniała postulatu Steinlaufa i nie dawała „dostatecznego oparcia moralnego", aby Zagładę co najmniej zaakceptować. Czy nie oferowała „jednoznacznego dychotomicznego modelu moralności”, który pozwalał „przetworzyć doświadczenie Zagłady" i wpisać je w spójny system społecznych wyobrażeń o porządku świata? 
„Antysemityzm to struktura myślowa porządkująca świat. «Żyd - świętokradca, czarownik i kidnaper, jest sługą szatana, mieszkańcem antyświata, uczestnikiem antywspólnoty. Wszystko, co w ludzkim świecie zakazane, tam przekształca się w nakaz» [Tokarska-Bakir, 2004, s. 62]. Antyświat wobec świata. Zło wobec dobra. Mentalność antysemicka to «myślenie, które utrzymuje pogrom w stanie możliwości» [Tokarska-Bakir, 2004, s. 64]. Pogrom jednak to zaledwie pars pro toto: prefiguracja Zagłady - fragmentaryczna i nieostateczna z konieczności. Z konieczności natury praktycznej. Teoretycznie bowiem - jeśli chodzi o zasadę - ideałem w antysemickim świecie jest całkowite zniknięcie żydowskiego antyświata" (Janicka, 2008, s. 239).

Zagłada i kultura antysemicka nie tworzyły kontrastu, lecz kontinuum. Definicja „Żyda” była dana. Podobnie „Żyd” jako poddany władzy spojrzenia i zatrzaśnięty w ostatecznej tożsamości - ostatecznie ubezwłasnowolniony - nie był wojennym wynalazkiem, lecz wytworem antysemickiej kultury. W godzinie Zagłady zmianie uległy konsekwencje władzy większości i ubezwłasnowolnienia mniejszości. Od większościowej władzy spojrzenia zależało żydowskie być albo nie być. Wytwarzanie „Żyda” zwane było rozpoznawaniem, a oznaczało wydanie na śmierć lub od razu uśmiercenie. Natomiast przejście od fantazmatów eliminacyjnych do eksterminacyjnych, artykułowanych przed wojną także w Polsce, nie było istotnym novum ${ }^{43}$. Stanowiło ujawnienie, wydobycie na powierzchnię struktury, która pozostawała niejako w uśpieniu:

„pogląd, że prawdziwie groźny antysemityzm jest wynalazkiem nowoczesnym, [...] nie wypada przekonująco w konfrontacji z materiałem etnograficznym [...] - zwłaszcza [...] z perspektywy samych Żydów. Przednowoczesny antysemityzm, religijny, etniczny i społeczny w narracji symbolicznej wyznaczał im prawdziwe «miejsce niebezpieczne», które w każdej chwili mogło zniknąć z powierzchni ziemi. [...] Oko przednowoczesne [...] «[b]ez wzruszenia» przyglądać się mogło jedynie temu, jak na Żydów spada zasłużona kara [...], nie tyle ich życie, co przede wszystkim ich śmierć uznając za «część odwiecznego ładu Bożego na ziemi»" (Tokarska-Bakir, 2004, ss. 66, 68).

„Historia Zagłady jako idei zaczyna się wraz z antysemityzmem” (Janicka, 2008, s. 239). W obrębie kultury antysemickiej możemy zatem mówić „o czymś w rodzaju idealizmu obiektywnego z cechującym go napięciem między tym, co jest, a tym, co być powinno" (Janicka, 2008, s. 239). Z tego punktu widzenia Zagłada oznaczała uzgodnienie wymiaru rzeczywistego z postulowanym i pożądanym. Jej historię można traktować jak „kronikę zapowiedzianej śmierci”44. Kultura antysemicka pozwalała zintegrować Zagładę

43 Postulat eksterminacji był obecny w publicystyce oraz karykaturze prasowej. (Ekspresję fantazmatów eksterminacyjnych można było oglądać na wystawie: „Obcy i niemili”. Antysemickie rysunki z prasy polskiej 19191939, kurator Dariusz Konstantynów, Żydowski Instytut Historyczny im. Emanuela Ringelbluma, 15 października 2013 - 31 marca 2014. Niestety, katalog wystawy nie zawiera ilustracji.) Jesienią 1936 roku w samej Warszawie okrzyki „Śmierć Żydom!”, z towarzyszeniem hajlowania, wznoszono podczas wieców antysemickich na Politechnice Warszawskiej, w szkole Wawelberga i Rotwanda oraz na Uniwersytecie Warszawskim. „Naturalnie, manifestacje te nie obyły się bez tłuczenia szyb w różnych punktach na Nowym Świecie. Między innymi sklep Hirszfelda wyglądał jak po przejściu pogromu. [...] Młodzież wiecowała w obrębie Uniwersytetu. Wiec skończył się w godzinach, kiedy wierni wychodzili z kościoła Św. Krzyża. W obliczu tłumu młodzież rzucała się na przechodzących Żydów z okrzykiem: «Śmierć Żydom!»..." (Krzywicki, 2009, s. 113). W Szkole Głównej Handlowej ONR rozdawał ulotki z zapowiedzią: „Mocni duchem, zwarci i posłuszni, silni masą bronić będziemy swej pozycji i zwyciężymy, niosąc zagładę Żydom i ich uniżonym służalcom” (Krzywicki, 2009, s. 86).

44 Sformułowanie Piotra Bratkowskiego nawiązuje do tytułu powieści Gabriela Garcíi Márqueza (por. Bratkowski \& Keff, 2013, ss. 112-114). 
w obrębie przyjętej wizji świata jako odpowiadającą wyobrażeniom o porządku rzeczy. Oferowała zespół racjonalizacji i przekonań moralnych uzasadniających większościowe postawy i zachowania wobec ginących Żydów. Przedstawiała sobą system pozwalający przyswoić Zagładę, ale inaczej niż pragnęliby tego teoretycy kultury posttraumatycznej. Dla Marii Orwid czy Michaela C. Steinlaufa dostrzec Zagładę „prawdziwie czy też w pełni" to zerwać z kulturą antysemicką raz na zawsze. Tymczasem logika fundująca i podtrzymująca naród polski jako wspólnotę wyobrażoną integrowała Zagładę w poetyce pomników wdzięczności, nie zaś wyrzutów sumienia: jako akt konieczności historycznej, o ile nie - sprawiedliwości dziejowej. Ustanawiała ciągłość zamiast zerwania. Spójność zamiast niespójności. Choć nie podzielam szczegółowego rozpoznania przyczyn tego stanu rzeczy autorstwa Aleksandra Smolara, zgadzam się z jego orzeczeniem, że

„[w]ydarzenia wojenne i bezpośrednio powojenne wzmocniły jeszcze poczucie obcości i wrogości. Okoliczności sprzyjały utrwaleniu antyżydowskich stereotypów. Doświadczenia wojny nie prowadziły do kompromitacji postaw antysemickich" (Smolar, 1986, s. 127).

Zagłada potwierdziła i wzmocniła kulturę antysemicką zamiast ją skompromitować. Logika Zagłady została przez polską większość zaakceptowana i była przez nią potwierdzana - myślą, mową, uczynkiem i zaniedbaniem - także po Zagładzie, czyli po zakończeniu wojny (por. Skibińska, 2011b; Żbikowski, 2011).

\section{Pamięć przyswojona w teorii i praktyce}

Jan Tomasz Gross jest autorem obserwacji, że „los żydowskich współobywateli tkwi w centrum doświadczenia okupacyjnego polskich mieszkańców każdej miejscowości”45 Na tej podstawie można by domniemywać, że pamięć Zagłady jako doświadczenia centralnego została następnie traumatycznie wyparta lub padła co najmniej ofiarą zmowy milczenia. W moim odczuciu należy jednak odwrócić perspektywę i zapytać, czy Zagłada - choć fizykalnie bliska ciału jak koszula „po Żydzie” - percepcyjnie nie lokowała się na peryferiach polskiego doświadczenia: psychicznie odległa, poznawczo i aksjologicznie problematyczna w ograniczonym stopniu albo wcale ${ }^{46}$. Tego typu (nie)wrażliwość była wszak pozytywnie weryfikowana przez mechanizmy kontroli wewnątrzgrupowej oraz wszechobecną instytucję Kościoła katolickiego, postrzeganą jako moralna ostoja i wyrocznia. Nie było alternatywnego systemu o porównywalnej prawomocności, na gruncie którego mogłyby rozwinąć się i znaleźć wyraz wątpliwości. Systemu, w którym

45 „[...] Holokaust, Zagłada Żydów, dokonała się wśród nas. Ściślej: wśród polskiego społeczeństwa, wśród pokolenia naszych rodziców i dziadków, przy świadkach, na oczach biorących w niej udział na różne sposoby «tłumów gawiedzi»" (Gross, 1998, s. 58).

46 O to samo warto by zapytać w odniesieniu do innych krajów Europy Środkowej i Wschodniej. Odnosząc się do przebiegu Zagłady na Litwie i obecnej polityki historycznej państwa litewskiego w tej sprawie, Leonidas Donskis napisał: „Żydzi nie należą do nas, nie są częścią Litwy. Są nieważnym, niewygodnym szczegółem, okolicznością, przypisem w historycznej rozprawie. Są przeszkodą. Przez nich nie możemy wystawić galerii naszych bohaterów, spisać heroicznej narracji, o jakiej marzymy. [...] [B]ędziemy wznosić kolejne pomniki naszej traumy i upokorzeń Zamiast stawiać czoło problemom i słabościom naszego kraju, będziemy zwalczać tych, którzy ośmielają się myśleć i mówić co innego" (Donskis, 2013, s. 37). Więcej na ten temat: Arad, 2012; Perchoc, 2010; Stryjek, 2011. Krajem, który wsparł litewską politykę historyczną na forum europejskim bez żadnych hamulców, okazała się Polska. 
okazjonalne i odosobnione współczucie i/lub sprzeciw nie zawisałyby w próżni spoŁecznej i kulturowej, lecz mogłyby prowadzić do rewizji przekonań, przywiązań, postaw i w konsekwencji zachowań.

Zagłada została przyswojona na poziomie potocznym - w wymiarze zarówno teoretycznym, jak i praktycznym. Potwierdziły to doświadczenia badaczy terenowych. Jako pierwszy zaś hipotezę o milczeniu i wyparciu doświadczenia Zagłady sfalsyfikował Claude Lanzmann - tyleż spektakularnie, co nieintencjonalnie (w fazie przygotowań do realizacji Shoah reżyser w ogóle nie widział potrzeby udania się do Polski). Lanzmann zarejestrował mianowicie popularny przykład teoretycznego przyswojenia Zagłady. Chrześcijanie licznie zgromadzeni w progach rzymskokatolickiej świątyni w miejscowości Chełmno nad Nerem w latach siedemdziesiątych XX wieku wyjaśnili mu, jak doszło, do czego i dlaczego - z uwzględnieniem wątku tak zwanego żydowskiego złota. W ich ujęciu Zagłada była częścią teodycei jako nierychliwa, ale sprawiedliwa kara za ukrzyżowanie przez Żydów Jezusa Chrystusa. W Chełmnie nad Nerem, od grudnia 1941 do kwietnia 1943 roku, Niemcy zgładzili około trzysta tysięcy Żydów - mężczyzn, kobiet i dzieci - przy użyciu ciężarówek z rurami wydechowymi odprowadzającymi spaliny do wnętrza pojazdów.

Innym narzędziem przyswojenia Zagłady na poziomie teorii było (i pozostaje) konceptualizowanie antysemityzmu jako antykomunizmu czy antybolszewizmu - z jednej strony usankcjonowane przez Kościół katolicki i utrwalane przez polską propagandę antysemicką od roku co najmniej 1905, z drugiej zaś wyłożone przez Hitlera w Mein Kampf i konsekwentnie eksponowane przez propagandę hitlerowską. Tak w oczach Kościoła, jak w optyce Hitlera zagrożenie bolszewizmem osiągało rozmiary apokaliptyczne, a walka z nim awansowała do rangi starcia dobra ze złem. Krucjata antybolszewicka i antybolszewicka misja cywilizacyjna operowały poetyką millenarystyczną i nosiły cechy projektów mesjanicznych. Niezależnie od doktrynalnych rozbieżności państwo kościelne utrzymywało stosunki dyplomatyczne z państwem Hitlera od jego powstania do chwili upadku, konsekwentnie powstrzymując się od krytyki nazizmu ${ }^{47}$. Mit żydokomuny harmonijnie wpisywał się w antyjudaizm i antysemityzm. Czerpał legitymację z potężnych pokładów tradycji i źródeł instytucjonalnych.

„¿Żydokomuna», stereotyp wykorzystywany w walce politycznej, ale i utarty zwrot sugerujący, że niemal wszyscy Żydzi są wyznawcami komunizmu, wciąż się przewijał w myśleniu i języku szerokich kręgów Polaków co najmniej od połowy lat trzydziestych XX wieku. Dużej części polskiego społeczeństwa - obok «zwyczajnego» antysemityzmu - posłużył za moralne alibi dla pasywnej postawy wobec dokonującego się na jego oczach niemieckiego mordu na prawie trzech milionach polskich Żydów. Niektórych - było ich co najmniej kilkanaście tysięcy - z podobnych pobudek zachęcit do współudziału w tym mordzie" (Żbikowski, 2011, s. 71).

47 Zawarcie konkordatu z Trzecią Rzeszą w 1933 roku było ze strony Watykanu demonstracyjnym przełamaniem izolacji państwa Hitlera na arenie międzynarodowej. Autorami tego sukcesu dyplomatycznego byli niemiecki minister spraw zagranicznych Joachim von Ribbentrop i nuncjusz apostolski w Niemczech Eugenio Pacelli, późniejszy papież Pius XII. 
Prócz racjonalizujących uzasadnień kultura antysemicka dostarczała zatem także legitymacji moralnej dla zagłady Żydów. W tym sensie można tylko zgodzić się z Anną Zawadzką, która twierdzi, że „temat żydokomuny należy do badań nad Zagładą” (Zawadzka, 2009, s. 204).

Tyle o potocznym przyswojeniu teoretycznym. Potoczne przyswojenie praktyczne można by nazwać „pamięcią specyficzną” - za badaczką pamięci społecznej o byłym niemieckim nazistowskim obozie natychmiastowej zagłady Żydów Treblinka II, Martyną Rusiniak. W komorach gazowych Treblinki w latach 1942-1943 życie straciło blisko milion Żydów. Teren poobozowy, podobnie jak w Chełmnie nad Nerem, Birkenau, Sobiborze, Bełżcu i na Majdanku, był systematycznie przekopywany przez ludność miejscową w poszukiwaniu tzw. skarbów:

„Lata 1943-1950 należą do okresu budowania w świadomości społeczeństwa obrazu Treblinki. [...] Wyczyny poszukiwaczy bezcześciły pamięć pomordowanych, zarazem świadczyły o znajomości historii wojennej byłego obozu. [...] Następnie w latach 50. ubiegłego wieku pamięć organów władzy o Treblince nieco przygasła, utrzymała się jednak pamięć lokalna. Była to jednak pamięć specyficzna, a mianowicie miejscowych poszukiwaczy o tym miejscu jako o «Eldorado Podlasia»" (Rusiniak, 2008, s. 93).

„Pamięć specyficzną" ukróciło dopiero zalanie betonem miejsca kaźni w początkach lat sześćdziesiątych XX wieku ${ }^{48}$.

Wariant „pamięci specyficznej”, kultywowany do dzisiaj w skali całego kraju, dokumentuje projekt fotograficzny Łukasza Baksika Macewy codziennego użytku (2008-2012). Macewy jako płyty chodnikowe, krawężniki, progi, żarna, cembrowiny piaskownic dla dzieci, narzędzia szlifierskie; obora czy stodoła zbudowana z macew; także nagrobki chrześcijańskie, na których można odczytać fragmenty hebrajskich napisów. Wszystko jawnie, alfabetem do wierzchu. Na cmentarzu żydowskim raziły. Tu są na swoim miejscu. Elementy ładu, stylu życia. Narzędzia porządkowania i usprawniania świata czyniące go miejscem oswojonym i wygodnym. Podobnie jak budynki dawnych synagog i domów modlitwy przekształcone w remizy straży pożarnej, sklepy, kina, puby, restauracje, zakłady pogrzebowe czy domy mieszkalne z fotograficznego cyklu Niewinne oko nie istnieje (2006-2008) Wojciecha Wilczyka. Bliskie, powszednie, udomowione właśnie. Wpisane, wplecione czy dosłownie wbudowane w tkankę codzienności. Ikony nieproblematycznego objęcia w posiadanie. Figury powszechnej i powszedniej narracji.

Autorzy obu projektów podkreślają w swoich wypowiedziach „wchłonięcie”, „przyswojenie” (sic!), swoistą „asymilację”, „wtopienie się w krajobraz” dokumentowanych macew i synagog ${ }^{49}$. Obaj mają świadomość, że jest to asymilacja przez unicestwienie

48 Decyzję o wylaniu betonu zatwierdziło prezydium Wojewódzkiej Rady Narodowej na początku 1961 roku. Realizację całości założenia pomnikowego ukończono w roku 1963 (por. Rusiniak, 2008, ss. 46, 48).

49 „Iwona Kurz: Jednocześnie to rozpoznawanie, które Niewinne oko nie istnieje umożliwia, pokazuje także rzecz zupełnie inną: po pierwsze, że w ogóle była w Polsce jakaś inna rzeczywistość architektoniczna, a zatem kulturowa, a po drugie, że w pewnym sensie ona i związana z nią przeszłość zostały jakoś wchłonięte, przyswojone. Wojciech Wilczyk: Tak, zostały swoiście zasymilowane...

Iwona Kurz: Można gorzko powiedzieć, że w końcu zasymilowaliśmy kulturę żydowską - po jej końcu" (Kurz \& Wilczyk, 2011, s. 299). 
podmiotu ${ }^{50}$ - czy może jeszcze inaczej: asymilacja pod warunkiem sine qua non unicestwienia podmiotu, co może odsyłać do pytania o logikę idei asymilacji w ogóle. Baksik i Wilczyk opowiadają jednocześnie o społecznym, obyczajowym kontekście pracy terenowej. Wojciech Wilczyk zwraca uwagę na trwałość pamięci:

„W Polsce wszyscy doskonale wiedzą, który budynek był synagogą lub przed wojną należał do «Żyda». Ta pamięć trwa i nie dotyczy wyłącznie pokolenia pamiętającego obywateli polskich narodowości żydowskiej sprzed Zagłady. [...] [P]amięć o dawnych właścicielach jest w Polsce ciągle żywa, a proces asymilacji [...] dotyczy tylko szaty zewnętrznej. [...] [W] trakcie robienia zdjęć byłem pytany, co robię, a częściej «dla kogo» to robię i «na czyje» zlecenie; czasami te rozmowy były dłuższe, pojawiały się w nich także resentymenty antysemickie i językowe stereotypy jakby rodem z prasy dwudziestolecia międzywojennego, co mnie zresztą mocno zaskoczyło" (Kurz \& Wilczyk, 2011, ss. 299-300).

Łukasza Baksika zastanawia, że o ile Niemcy zazwyczaj odwracali macewy napisami do dołu, o tyle Polacy zazwyczaj tego nie czynili:

„Pewne jest, że w taki sposób nagrobki żydowskie wykorzystywano we wszystkich częściach Polski. [...] Starcie hebrajskich liter zajęłoby kilka minut. Dlaczego tego nie robiono? Myślę, że te napisy były zupełnie transparentne, pozbawione jakiegokolwiek znaczenia, choć zakładam, że znane było pochodzenie prefabrykatu. Mnie (nas?) kłują w oczy, użytkowników [...] - nie. Dlaczego?" (Baksik, 2013, s. 110)

Treścią naoczności - jeśli nie ostentacji - wizualnego komunikatu jest potwierdzenie Zagłady i akceptacja jej materialnych skutków. Na pytanie o wiedzę użytkowników macew odpowiada Joanna Tokarska-Bakir, przywołując spostrzeżenie Pierre’a Bourdieu:

50 „Oczywiście zdaję sobie sprawę, że nie tylko żydowskie cmentarze niszczono. [...] Wydaje mi się jednak, że przez ciąg zdarzeń, który był zaplanowany, a plan wykonany, sytuacja dziedzictwa kulturowego Żydów (polskich) znacząco różni się od przykładów ze starożytności czy od sytuacji cmentarzy niemieckich, niszczonych w naszym kraju już po wojnie. Ten ciąg zdarzeń zakładał przede wszystkim eksterminację ludzi, ale zaraz za nią zniszczenie wszelkich oznak ich obecności, a wreszcie zatarcie pamięci o nich" (Baksik, 2013, s. 103).

Na temat obróbki i przyswojenia żydowskich cmentarzy por. także Żmijewski, 2013. W zeszłym roku trafiły do mnie fotografie z drugiej połowy lat pięćdziesiątych: trzy pokolenia rodziny Janickich zażywają wywczasu na cmentarzu żydowskim w Kępnie (Wielkopolska), w dzielnicy nazywanej Kamczatką. Najstarsza osoba urodziła się w roku 1907, najmłodsza jest niemowlęciem. Większość macew w tym czasie była już rozdysponowana po mieście i okolicy. W roku 1948 wzniesiono z nich pomnik władzy ludowej z piastowskim orłem (do roku 1920 Kępno było miastem niemieckim). Cioci Gertrudzie z Kalisza dziękuję za sporządzenie i przesłanie kopii fotografii. Cioci Anieli z Kępna dziękuję za uzupełnienie obrazów komentarzem.

„Jeszcze podczas okupacji niemieckiej macewy były wykorzystywane jako materiał budowlany do brukowania dróg oraz podczas budowy osiedla dla przesiedleńców niemieckich. Dewastacja cmentarza trwała także po wojnie. W 1948 r. komunistyczne władze wykorzystały macewy z kępińskiego kirkutu do budowy Pomnika Bohaterów, który stanął na kępińskim rynku. Zostały również użyte do budowy pomnika poświęconego «utrwalaczom władzy ludowej», czyli członkom Urzędu Bezpieczeństwa, Milicji Obywatelskiej i Korpusu Bezpieczeństwa Wewnętrznego. Pomnik stał na skwerku obok szpitala, gdzie obecnie znajduje się plac zabaw. Odzyskane po rozbiórce pomników macewy zabezpieczono przy synagodze w Kępnie. Kirkut był też plądrowany przez niektórych mieszkańców Kępna, którzy skuszeni opowieściami o bogactwie Żydów, przekopywali cmentarz w poszukiwaniu kosztowności. Również macewy nadal były grabione i wykorzystywane jako materiał budowlany. W 1959 roku cmentarz został przejęty przez skarb państwa. Górkę zlikwidowano, ziemia cmentarna posłużyła między innymi jako podkład do budowy dróg" (opracowała Patrycja Karwan-Makosch (b.d.) na podstawie książki Żydzi kępińscy [Łapa (Red.), 2008].

W 2008 roku w Kępnie pojawił się Łukasz Baksik: „Gdy robiłem zdjęcia, podjechali funkcjonariusze straży miejskiej i zostałem wylegitymowany. Po strażników zadzwonił mieszkaniec któregoś z sąsiadujących z synagogą domów. Pomyślałem sobie, że teraz wokół tego miejsca panuje zupełnie inna atmosfera. Budowie pomnika towarzyszyła bowiem obojętność, która wciąż była obecna rok później, gdy pani Dziewiszek, p.o. burmistrza, pisała do Zarządu Gminy Wyznaniowej Żydowskiej w Warszawie w sprawie przekazania zarządowi miasta budynków, które należały do gminy: «Biorąc pod uwagę fakt zupełnego opuszczenia tut.[ejszego] miasta i niezamieszkiwania od 1945 r. przez osoby wyznania mojżeszowego należy przyjąć, że restytucja Gminy wyznaniowej żydowskiej w Kępnie nie nastąpi w ogóle wzgl.[ędnie] mogłaby nastąpić dopiero w dalszej przyszłości». W odpowiedzi otrzymała zgodę, zaś «Jako ekwiwalent za korzystanie z tych budynków proponujemy, by Zarząd Miejski zajął się doprowadzeniem do porządku cmentarza żydowskiego - w razie jego zniszczenia - i otoczył go stałą opieką»” (Baksik, 2013, s. 106). 
„Ich wiedza nie różni się od naszej. [...] W sprawie, o której mowa, wcale jednak nie chodzi o wiedzę. Chodzi o zgodę" (Tokarska-Bakir, 2012b, s. 9) 91.

Ta sama zgoda - zdarzało się, że wraz z potwierdzeniem i akceptacją - manifestowała się na najwyższym szczeblu: $w$ dokumentach obu pionów polskiego państwa podziemnego, cywilnego i wojskowego (por. Libionka, 2006). W sprawie Zagłady zatem chodziŁo - chodzi - o zgodę jako postawę dominującą, obejmującą wszystkie warstwy spoŁeczne i transgeneracyjną.

„Przysucha - środek miasta. Obok kościół, komisariat, rynek. Cała obora zbudowana z macew, które bardzo dobrze widać. Tam już nie ma żadnego nagrobka na cmentarzu" (Kowalska \& Baksik, 2012, s. 20).

„Nie próbowano ukryć wstydliwego faktu” - pisze Baksik (Baksik, 2013, s. 119) - a i dzisiaj użytkownicy macew najczęściej nie dostrzegają problemu - niezależnie od pozycji społecznej, w tym także od stopnia wykształcenia. Dotyczy to niejednokrotnie osób o statusie społecznych autorytetów, jak na przykład duchowni rzymskokatoliccy czy dyrektor jednej ze szkół podstawowych, który szkolne ogrodzenie z macew uważa za „normalne, oczywiste” - z kośćmi Żydów wystającymi z ziemi wokół boiska włącznie (Kowalska \& Baksik, 2012, s. 19). To samo zjawisko wśród polskiej inteligencji zaobserwowała Joanna Tokarska-Bakir:

„Momentem, w którym sama uzyskałam wgląd w to, jaki jest stan rzeczy polsko-żydowskich w świadomości polskich inteligentów, było spotkanie z bębnem z Tory. Robi się go z pergaminowych kart żydowskich ksiąg modlitewnych znalezionych w synagogach. Bęben z Tory jest ludowym instrumentem pospolicie występującym w Radomskiem czy na Roztoczu, świetnie znanym etnografom i zbieraczom folkloru muzycznego. [...] Jeśli w ogóle rozmawia się o tym instrumencie, to na ogół w kategoriach «ochrony dziedzictwa narodowego». Nie, nie chodzi o Żydów. Chodzi o ostatnich wiejskich muzykantów i o to, jak bardzo ucierpi ich ginąca kultura, gdy odbierze się im te bębny i pochowa je na żydowskim cmentarzu. [...] W podobnym duchu - «niszczenia dziedzictwa ludowego» - mówi się też czasem o krytyce wielkanocnego zwyczaju wieszania Judasza («wodzenia Judosza»), wciąż kultywowanego gdzieniegdzie na Podkarpaciu [por. Pawłowski, 2001, s. 13]" (Tokarska-Bakir, 2012b, s. 8).

Chodzi tu o ludzi wykształconych, świadomych, wyposażonych w kompetencje kulturowe i prestiż społeczny. Można ich nazwać prawodawcami i decydentami, producentami sensów. Definiując dziedzictwo narodowe, legitymizują taki, a nie inni kształt wspólnoty - jej pamięci i tożsamości. Odstępując od problematyzacji danego zespołu zjawisk, rozstrzygają o umiejscowieniu ich w obszarze normy i oczywistości.

Dla porównania, patrząc na „macewy codziennego użytku”, Jan Tomasz Gross „normalizuje" zjawisko w obrębie radykalnie przeciwstawnego paradygmatu i układu odniesienia:

„Więc jak to się dzieje, że kiedy patrzę na fotografie Łukasza Baksika, nie czuję oburzenia? Może wiąże się to jakoś z tym, że wydawani na śmierć i mordowani przez współziomków

51 „To właśnie jej nie mają ludzie tacy jak Łukasz Baksik, autor Macew codziennego użytku, czy Wojciech Wilczyk, autor albumu Niewinne oko nie istnieje. [...] Nie zatka im się ust «narodową lojalnością», «klasową solidarnością» ani «racją stanu»" (Tokarska-Bakir, 2012b, s. 9). 
Żydzi byli zakopywani przez morderców byle gdzie? Może więc te rozrzucone po Polsce macewy wywędrowały w poszukiwaniu nieżyjących i są tam, gdzie je Baksik sfotografowat, niejako na właściwym miejscu?" (Gross, 2012, s. 15).

W obu ujęciach los niepochowanych ofiar Judenjagd, których zwłoki spoczywają nadal - siedemdziesiąt lat po Zagładzie - w nieoznaczonych miejscach na łąkach i w lasach, w przydrożnych rowach, przydomowych ogródkach i obejściach, jest tak samo normalny i oczywisty jak los macew. Tyle że to, co dla Grossa jest krajobrazem spoŁeczno-kulturowym naznaczonym antysemicką przemocą i wykluczeniem, mordem i rabunkiem, dla większości pozostaje nienacechowanym i nieproblematycznym krajobrazem tout court. Podobnie jak wysyp swastyk, neonazistowskich znaków runicznych i napisów w rodzaju „Żydy do pieca”, „Adolf Hitler”, „Łowcy Żydów” czy „Jude raus” na murach polskich miast, które fotografuje Wojciech Wilczyk. Anna Zawadzka pisze o nich:

„Scenografia dnia codziennego milionów ludzi. Dekoracja mijana w drodze na przystanek, do supermarketu, ze szkoły, po samochód, z psem na spacer, do babci z zupą w termosie. Dziewczyna idzie do szkoły, śmierć żydowskiej kurwie, kobieta niesie ze sklepu chleb i mleko, fanatycy od urodzenia, mężczyzna wyprowadza psa na spacer, Polska dla Polaków, dzieci grają w piłkę na podwórku, Anty Jude, toi toi, swastyka, kwiatki na balkonie, swastyka, firanka w oknie, krzyż celtycki, Lewiatan promocja słodycze, Jebać Żydów Maczetami, xero, jebać Żydów, rajstopy, śmierć Żydom, zdrowa żywność, jebać cracovie kurwe, krzaki forsycji zimą brązowe. [...] Zabijanie Żydów jest bezkolizyjnie i harmonijnie wtopione w krajobraz. [...] $\mathrm{Na}$ mocy kultury polskiej antysemityzm staje się elementem pejzażu. Można by rzec: pełna asymilacja (zabijania) Żydów" (Zawadzka, 2014, ss. 15-16)52.

Co się zatem tyczy polskiego doświadczenia Zagłady, te i inne wzory zachowań większościowych trudno uznać za „powtarzające się, lecz próżne próby ujęcia tego doświadczenia w przyjęte ramy ideologiczne i moralne", jak chciałby Michael C. Steinlauf (Steinlauf, 2001, s. 132). Trudno dostrzec oznaki „urazu, ranę, ślad po bolesnym przeżyciu” (por. Orwid, 2009, s. 7) tam, gdzie mamy do czynienia z pamięcią przyswojoną w trybie konceptualizacji i praktyk społecznych. Być może zresztą jest to nie tyle - czy nie tylko - pamięć, lecz także prosta kontynuacja wzoru stanowiącego część społeczno-kulturowej oczywistości.

52 Problem został niezwłocznie unieważniony przez największy dziennik opinii w Polsce: „Kibole zabrali nam mury, żeby wieszać na nich swoje ogłoszenia. A my się przyzwyczailiśmy” (por. Olszewski, 2014, s. 18). Autor tekstu zastosował w tym celu procedurę trzech kroków: a) wprowadzenie bezpiecznego podziału „my-oni”; b) ulokowanie zła po stronie „onych”; c) wytworzenie „winy obojętności” obarczającej „nas” postrzeganych jako co najwyżej „bierni świadkowie”. Stało się tak mimo wyraźnego zastrzeżenia sformułowanego przez Wojciecha Wilczyka: „W prasie funkcjonuje termin «kibol». No i jesteśmy my [...]. Mamy wysokie poczucie estetyki, jesteśmy tolerancyjni i tak dalej. Uważamy, że wojna na murach to sprawa kiboli. Ale przecież za to, co dzieje się w przestrzeni publicznej, odpowiadają zarówno ci, którzy malują obraźliwe hasła (nie nazywam ich nigdy kibolami), jak i ci, którzy na nie patrzą. Gdyby istnieli ludzie, którym te napisy naprawdę przeszkadzają, toby tych napisów nie było. [...] Na murze szkoły przy ul. Nawojki w Krakowie było graffiti przedstawiające papieża [Jana Pawła II - E.J.]. Kiedyś pojawiło się na nim hasło: «Żyd, oszust, aktor». Natychmiast napisały o tym lokalne gazety, «miejsce zbrodni» otoczono płotem, a napis zeskrobano razem z muralem (obecnie wisi tam baner ze zdjęciem tego malowidła). [...] Reakcje więc są, ale dotyczą, jak widać, wybranych sytuacji” (Szymkowiak \& Wilczyk, 2014, s. 18). 


\section{Ewolucja strategii przyswojenia}

Postuluję zmianę kwalifikacji zjawisk, które zwolennicy koncepcji polskiego doświadczenia Zagłady jako traumy uważają za dowody nieprzyswojenia tego doświadczenia. Innymi słowy: na narracje spod znaku Ukrzyżowania i żydokomuny proponuję spojrzeć jak na sposoby przyswojenia Zagłady, czyli udane „próby ujęcia tego doświadczenia w przyjęte ramy ideologiczne i moralne" (Steinlauf, 2001, s. 132). Równolegle do nich w obszarze dyskursu proponowanego po 1945 roku przez kolejne formacje u władzy lub autorytety społeczne, jak na przykład inteligencja laicka, inteligencja katolicka i/lub Kościót - kształtowały się wzory opowieści o Zagładzie, które omijały koleiny wyżłobione w potocznej mentalności przez fantazmaty Ukrzyżowania i żydokomuny. Jeszcze w latach czterdziestych zaczęło się to wiązać z zacieraniem tożsamości ofiar. Jak gdyby antysemityzm był jedynym możliwym polem/trybem reprezentacji żydowskiej obecności i nieobecności, poza antysemityzmem zaś reprezentacja taka była niemożliwa. Stosowano metody takie, jak: uniwersalizacja humanistyczna, uniwersalizacja antyfaszystowska, polonizacja, wreszcie chrystianizacja. W kolejnych wersjach w Zagładzie ginęli odpowiednio: ludzie, ofiary faszyzmu, Polacy, członkowie narodów Europy różnych wyznań ze szczególnym uwzględnieniem chrześcijan (por. np. Dawidowicz, 1981; Forecki, 2010b). Owe modele były jedynie pozornie alternatywne względem narracji spod znaku Ukrzyżowania i żydokomuny. Nie naruszały bowiem antysemityzmu jako przedustawnej ramy czy kontekstu odbiorczego opowieści. Antysemityzmu jako zjawiska, którego bądź nie należy, bądź nie wolno, bądź nie można, bądź nie da się sproblematyzować.

Świadoma jestem specyfiki każdej z wymienionych narracji. Nie jest moim zamiarem niwelowanie różnic między nimi. Uniwersalizacja humanistyczna na przykład miała z początku walor transgresji w kulturze, w której - z całkowicie odmiennych i nieporównywalnych względów - Żydzi byli, a Niemcy zostali pozbawieni statusu ludzi. (Dehumanizacja Żydów sięga korzeni antysemityzmu, czyli zarania chrześcijaństwa ${ }^{53}$.) Znamiona rewizji i transgresji spełniały na przykład tużpowojenne teksty Jerzego Andrzejewskiego, Ludwika Heringa, Juliana Przybosia czy Kazimierza Wyki (por. Andrzejewski, 1947, ss. 20-50; Hering, 2011, ss. 31-101; Przyboś, 1947, ss. 60-64; Wyka, 1985, ss. 139-178). Również motto Medalionów Zofii Nałkowskiej - „Ludzie ludziom zgotowali ten los" - miało potencjał rewolucyjny. Jednakże to, w jaki sposób obeszła się z nim polska kultura dominująca - zacierając tożsamość ofiar, eksponując tożsamość głównych sprawców i eliminując z pola widzenia obserwatorów uczestniczących - sprawia, że nie dosyć w Polsce przypominania, że „popioły były konkretne i żydowskie, a zbrodnia nie «przeciwko ludzkości», lecz przeciwko Żydom” (Grynberg, 1984b, s. 133) ${ }^{54}$. „Dzisiaj już wiemy na pewno, że podmiot i dopełnienie tego zdania mają inny zakres znaczeniowy,

53 Na temat dehumanizacji Niemców por. Kirchner, 2011, s. 580, 594; Tokarska-Bakir \& Grudzińska-Gross, 2012.

54 Por. także w tym samym zbiorze: Grynberg, 1984a. Ponadto zaś: Dunin, 2004; Zaleski, 2000. „To prawda, w sensie najważniejszym i najmocniejszym to ludzie ludziom. Ale wobec historycznego konkretu, w zależności od tego, kto mówi, deklaracja ta może przybierać rozmaite oblicza, niezbędne dla nas tu i teraz, a nie zawsze i dla wszystkich. Czasami trzeba po prostu powiedzieć: to Polacy. I dobrze zrozumieć, co mówimy” (Dunin, 2004, s. 74). 
niż nam się wydawało i niż byśmy sobie tego życzyli” (Gross, 2003c, s. 117). Krytyka uniwersalizmu humanistycznego jako fałszywego uniwersalizmu pozostaje w mocy tam, gdzie uniwersalizacji nie towarzyszy wyraźne wskazanie tożsamości ofiar oraz źródet, mechanizmów i społeczno-kulturowej legitymacji antysemityzmu, z którą wiąże się konieczność delegitymizacji nie tylko antysemityzmu, lecz także uprawomocniającej go kultury. Innymi słowy, krytyka ta pozostaje w mocy wszędzie, gdzie uniwersalizacji nie towarzyszy wskazanie na nierówne warunki dostępu do uniwersalnościj5 - np. do kategorii ludzi czy ludzkości.

Z różnych względów zatem wyszczególnione narracje nie prowadziły do konfrontacji z antysemickim paradygmatem ${ }^{56}$ i kulturą, której był wytworem. Nie mówiąc o tych spośród owych narracji, które operowały mutacją antysemickich struktur i treści - jak polonizacja sprzężona ze sprawą tzw. Encyklopedystów i chrystianizacja, której emblematami stały się: msza odprawiona przez Jana Pawła II w Birkenau w 1979 roku, wyniesienie na ołtarze Edyty Stein (beatyfikacja w 1987 roku, kanonizacja w roku 1998) czy polskie działania symboliczne w przestrzeni byłych niemieckich nazistowskich obozów Auschwitz I i Auschwitz II Birkenau (lata 1985-1993) (por. Forecki, 2010a; Heuner, 2003; Szurek, 2010b; Zubrzycki, 2014).

W tym kontekście nikły komunikaty nierespektujące granic społeczno-kulturowej dopuszczalności. W procesie recepcji neutralizowano głosy ofiar, które wypowiadały żydowskie doświadczenie Zagłady w Polsce do końca i bez ogródek (jak choćby Grynberg, Rudnicki czy Wygodzki). Nie komentowano wypowiedzi przedstawicieli grupy dominującej, które stawiały sobie za cel możliwie precyzyjne i pełne odzwierciedlenie realiów Zagłady, następnie zaś analizę i krytykę kultury dominującej (jak wspomniani już Andrzejewski, Hering, Przyboś czy Wyka). W głównym nurcie kultury większościowej w oparciu o korpus źródłowy - bogaty, nawet jeżeli rzecz ograniczyć do tekstów w języku polskim - nie wytworzył się ani kanon tekstów (por. Karolak, 2014), ani paradygmat opisu, który spełniałby jednocześnie dwa warunki: stanowił alternatywę dla opowieści spod znaku Ukrzyżowania i żydokomuny oraz uwzględniał tożsamość ofiar.

Po zakończeniu ponad dziesięcioletniej bitwy symbolicznej wokół klasztoru karmelitanek i żwirowiska w Auschwitz oraz wokół pola popiołów w Birkenau - nawet jeżeli z terenu przylegającego do obozu w Auschwitz nie usunięto tzw. krzyża papieskiego

55 Na temat krytyki monopolu uniwersalności oraz partykularnego interesu w zainteresowaniu uniwersalnością por. Bourdieu, 2006b. Na temat praktyk umożliwiających „funkcjonowanie efektywnych mechanizmów władzy wbrew ramom formalnym, jakie sobie narzuciła”, a więc przekształcających „formalnie egalitarne ramy prawne” w narzędzie nierówności, przemocy i wykluczenia por. Foucault, 2009, ss. 215-216. Foucault opisuje „«plus władzy», który zawsze przypisany jest tej samej stronie, nierówność pozycji rozmaitych «partnerów» wobec wspólnego regulaminu” jako „coś w rodzaju kontr-prawa”, co wprowadza „nieprzekraczalne dyssymetrie” i „Wyklucza wzajemność” (Foucault, 2009, s. 216). W szczególności myślę o następującym fragmencie wywodu autora, w którym termin „dyscypliny” pragnęłabym zastąpić terminem „kontekst społeczno-kulturowy”: „[S]ystemy prawne kwalifikują podmioty prawa wedle norm uniwersalnych, dyscypliny natomiast charakteryzują, klasyfikują, specyfikują, umieszczają na skali, plasują wokół normy, ustalają wzajemną hierarchię jednostek, w skrajnych zaś wypadkach dyskwalifikują i unieważniają. W każdym razie w tej czasoprzestrzeni, nad którą sprawują kontrolę i gdzie wprowadzają dyssymetrie swej władzy, dokonują [...] zawieszenia prawa” (Foucault, 2009, s. 216).

56 Na temat krytyki uniwersalizmu antyfaszystowskiego por. „Les doutes de l’antifascisme. Table Ronde, 16 février 1990", 2010 
i nie zdjęto krzyża dominującego nad Birkenau - Zagładę „zwrócono” Żydom. Początków procesu restytucji można upatrywać w roku 1985, w panice moralnej, jaka wybuchła w Polsce w związku z premierą Shoah Lanzmanna. Popularna stała się wówczas opowieść o Polakach jako świadkach Zagłady i polskiej winie obojętności - opowieść zaproponowana przez Jana Błońskiego w tekście Biedni Polacy patrza na getto ${ }^{57}$ i stanowiąca maksimum ustępstw grupy dominującej wobec presji zdefiniowanej jako pochodząca z zewnątrz: spoza granic kraju, a przede wszystkim spoza granic wspólnoty.

Po 2000 roku - w konsekwencji ogólnokrajowej debaty wywołanej książką Jana Tomasza Grossa Sąsiedzi i w rezultacie dalszych badań nad Zagładą - do obiegu publicznego weszła pula wiedzy o antysemityzmie przedwojennym, wojennym i powojennym, o skali rabunku i denuncjacji, o rzeczywistym położeniu Sprawiedliwych, o przemyśle pomocy ${ }^{58}$, o całopaleniach w Jedwabnem i gdzie indziej, o postawie polskiego państwa podziemnego i zbrojnego podziemia niepodległościowego. W miarę publikowania wyników kolejnych badań wiedza na ten temat staje się coraz pełniejsza i coraz szerzej dostępna. Nikt jej też praktycznie nie neguje.

Jako wypróbowane sposoby radzenia sobie z powyższym wróciły do łask narracje spod znaku Ukrzyżowania i żydokomuny. Na wysokim poziomie utrzymują się wskaźniki wiary w odpowiedzialność współczesnych Żydów za ukrzyżowanie Jezusa ${ }^{59}$ i wynikającej stąd wiary w rzekomy żydowski mord rytualny ${ }^{60}$. Fantazmat żydokomuny przeszedł

57 Zastosowanie zaproponowanej przez Błońskiego konceptualizacji por. Świda-Ziemba, 2010. Por. także krytyczna lektura tekstu Błońskiego: Żukowski, 2001, 2013.

58 Sformułowanie Jana Grabowskiego; por. Grabowski, 2008.

59 W badaniu przeprowadzonym w 2008 roku przez Jolantę Ambrosewicz-Jacobs z Centrum Badań Holokaustu Uniwersytetu Jagiellońskiego na pytanie „Czy na współczesnych Żydach ciąży odpowiedzialność za ukrzyżowanie Chrystusa?" twierdząco odpowiedziało 15,1\% ankietowanych (o ponad połowę więcej niż dziesięć lat wcześniej), 39\% nie miało na ten temat zdania. Badaną próbę stanowiło 1000 uczniów liceów i szkół zawodowych („Młodzi mają coraz mniej uprzedzeń wobec Żydów”, 2009; por. także Tokarska-Bakir, 2014).

Na podstawie badań powtarzanych przez zespół Ireneusza Krzemińskiego w latach 1992, 2002, 2012 można przypuszczać, że zmiana w tym zakresie nastąpiła około roku 2000. Antysemickie „postawy podzieliliśmy z dr Heleną Datner na swa rodzaje. Jeden, tradycyjny, oznacza postawy, w których wrogość do Żydów uzasadnia się tradycyjnymi religijnymi stereotypami, na czele z opinią, że Żydzi zawsze winni są śmierci Pana Jezusa. [...] Gdy w 1992 r. szukaliśmy uwarunkowań postaw antysemickich, religijność i praktyki religijne były jednym z pierwszych czynników wziętych pod uwagę. Wówczas okazało się, że między «naszym» antysemityzmem nowoczesnym a deklaracją religijności i praktykami religijnymi nie było prostej zależności. Sytuacja uległa dramatycznej zmianie w badaniu w 2002 r. - niezależnie od poziomu wykształcenia deklaracja silniejszej religijności i częstszych praktyk religijnych wpływała na postawy antysemickie. W różny sposób mierząc tę zależność, zawsze otrzymywaliśmy taki sam wynik: silnego wpływu religijności na antysemickie postawy" (Krzemiński, 2014; podkreślenia jak w oryginale). I słowo o młodzieży: „We wszystkich trzech badaniach, od 1992 do 2012 roku, najmłodsi badani (w wieku 18-24 lata) najrzadziej reprezentowali postawy antysemickie. Gdy jednak sprawdziłem, co się dzieje z najmłodszymi, kiedy stają się starsi, okazało się, że nabierają postaw antysemickich” (Krzemiński, 2014).

60 Badanie przeprowadzone w 2011 roku przez Centrum Badań nad Uprzedzeniami Uniwersytetu Warszawskiego wykazało, że około $10 \%$ ankietowanych wierzy i zdecydowanie wierzy, że Żydzi porywają chrześcijańskie dzieci, $56,4 \%$ natomiast ani się z tym zgadza, ani nie zgadza. „Było to ogólnopolskie badanie na próbie 620 internautów w wieku 15-35 lat. Badanie to miało na celu rozpoznanie, czy tego typu legendy występują wśród osób nowoczesnych, korzystających z dobrodziejstw współczesnych technologii” (Bilewicz \& Haska, 2012). Wynikom badania towarzyszył komentarz: „Tego typu mity o mordzie rytualnym występują głównie u osób o niskim wykształceniu, mieszkających na wsi i w mniejszych ośrodkach miejskich, w szczególności we wschodnich częściach kraju”. We wnioskach pominięto alarmistycznie wysoki procent tzw. niezdecydowanych - jak gdyby można było mieć stosunek neutralny do jednego z najbardziej śmiercionośnych przesądów antysemickich (por. dekonstrukcja kategorii obojętności w niniejszym tekście). W kwestionariuszu nie uwzględniono też zeświecczonych, zracjonalizowanych mutacji mitu.

Polski sondaż uprzedzeń z 2013 roku - przeprowadzony na próbie tysiąca osób i porównany z takimi samymi badaniami z roku 2009 - wykazał "gwałtowny wzrost antysemityzmu tradycyjnego". Blisko jedna czwarta respondentów uznała mianowicie, że Żydzi odpowiadają za śmierć Jezusa i dokonywali mordów rytualnych. „Na stałym 
reaktywację jako narzędzie racjonalizacji, normalizacji i moralnej legitymizacji większościowych postaw i zachowań wobec Żydów w czasie Zagłady i po Zagładzie. Zagłada została wpisana w logikę konfliktu międzygrupowego. W puli zjawisk objętych racjonalizacją, normalizacją i moralną legitymizacją na powrót znalazły się jednostkowe i zbiorowe zbrodnie na Żydach - nie mówiąc już o rabunku. Rzecz całą ułatwia awans do rangi oczywistości społeczno-kulturowej, jaki stał się udziałem paradygmatu antykomunistycznego, którego antysemicki potencjał jest nadal zbyt słabo zbadany i pozostaje nierozbrojony ${ }^{61}$.

Jednocześnie rekordy popularności bije dyskurs pomocowy - stale na fali wznoszącej. Jak odnotowuje Jan Grabowski:

„Dziś upamiętnianie Polaków niosących pomoc Żydom stało się jednym ze sztandarowych zadań IPN, MSZ oraz szeregu innych instytucji kultury i propagandy korzystających z państwowego mecenatu. Nie mija miesiąc, by nie ukazały się kolejne książki, broszury, wystawy objazdowe, stacjonarne i internetowe. Trwa intensywna akcja patriotycznej indoktrynacji w szkołach, organizowane są warsztaty dla nauczycieli, a Kościół katolicki też nie zasypia gruszek w popiele i - ustami swoich przedstawicieli rozmaitego szczebla - z zapałem podkreśla własne zasługi w tej właśnie materii. Szaleństwo upamiętniania polskiego bohaterstwa i poświęcenia zaowocowało już nawet wydaniem złotych [...] monet (sic!) poświęconych „Polakom Ratującym Żydów”. [...] [K]westia upamiętniania Polaków ratujących Żydów (UPRŻ) stwarza coś w rodzaju wąskiej kładki, na której spotykają się zgodnie (choć każdy $z$ trochę innych powodów) przedstawiciele politycznej lewicy, centrum, prawicy i skrajnej prawicy. A nawet [...] dołączają do nich lojalni Żydzi. Można wręcz powiedzieć, że UPRŻ jest jedynym tego rodzaju forum zgody narodowej w dzisiejszej Polsce"62.

Rozwój wydarzeń w ostatnich latach upoważnia do stwierdzenia, że UPRŻ - będące wytworem polskiej kompulsji wizerunkowej - sięgnęło rozmiarów psychozy, jeśli nie wręcz obłędu. W 2014 roku w rocznicę wyzwolenia obozu zagłady Auschwitz II Birkenau dziennikarze i eksperci zgodnie twierdzili, że jest to okazja odpowiednia dla uczczenia zasług narodu polskiego w ratowaniu Żydów. Rok wcześniej, w związku z rocznicą

poziomie utrzymuje się antysemityzm spiskowy i wtórny. Ogólne przekonanie, że istnieje «spisek żydowski», wyrażało w ubiegłym roku 63 proc. badanych (cztery lata wcześniej - 65 proc)”. Gdy z wynikami badania zapoznała się sejmowa komisja mniejszości narodowych, „część posłów miała pretensje do przedstawicieli organizacji mniejszości żydowskiej w Polsce, że nie broni nas [sic! - E.J.] za granicą. To zachowanie doskonale wpisuje się w definicję antysemityzmu wtórnego" (Wroński, 2014). Autorami badania są Michał Bilewicz i Mikołaj Winiewski.

61 Paradygmat antykomunistyczny opiera się na braku precyzji definicyjnej i odróżnorodnieniu, a następnie demonizacji, delegitymizacji i zastosowaniu podwójnych standardów wobec wszystkiego, co zostanie uznane choćby najzupełniej arbitralnie - za komunistyczne. I tak w jednym worku terminologicznym lądują np. założenia Bauhausu, idea sprawiedliwości społecznej, strzelanie do robotników i zbrodnie stalinowskie. Okres 1945-1989 w historii Europy Środkowej i Wschodniej podlega stalinizacji, zaś każdy akt gwałtu zostaje usprawiedliwiony a wręcz stanowi powód do chwały - jeśli tylko wypływał z antykomunistycznych pobudek. Znika kontrast między marksizmem jako filozofią społeczną i szkołą analizy krytycznej a „marleną”, czyli marksizmem-leninizmem, który jak dzisiaj antykomunizm - był fałszywą świadomością i maczugą na myślących inaczej oraz kwestionujących status quo. Analizę założeń i stawek paradygmatu antykomunistycznego, w dalszym ciągu odosobnioną mimo upływu lat, zawiera studium Anny Zawadzkiej (Zawadzka, 2009). Według autorki antykomunizm jest dzisiaj nie tyle dyskursem, ile zasadą legitymizującą dyskursy.

62 Jan Grabowski, Upamiętnianie Polaków niosących pomoc - tekst odrzucony przez „Gazetę Wyborczą” w styczniu 2014, następnie opublikowany na stronie internetowej Centrum Badań nad Zagładą Żydów przy Instytucie Filozofii i Socjologii PAN 31 marca 2014 roku (http://www.holocaustresearch.pl/index.php?mod=news\&show=285) (Grabowski, 2014a), następnie zamieszczony na stronie internetowej „Dziennika Opinii Krytyka Polityczna” 8 kwietnia 2014 roku (http://www.krytykapolityczna.pl/en/artykuly/opinie/20140408/grabowski-upamietnianie-polakow-niosacych-pomoc), po czym opublikowany pod tytułem W sprawie Zagłady Polska gola! w „Gazecie Wyborczej" z 26-27 kwietnia 2014, s. 30-31 (Grabowski, 2014b). 
wybuchu powstania w obozie zagłady w Treblince, Sejm uznał za stosowne przyjąć uchwałę składającą hołd Polakom z okolic Treblinki ratującym Żydów (por. Libionka, 2013, s. 6896 ${ }^{63}$. Nie towarzyszyły temu żadne starania o zachowanie pozorów. Nie próbowano stworzyć choćby wrażenia, że chodzi tu o coś innego niż wizerunek Polski i Polaków. Prezydent państwa - zaangażowany w UPRŻ - był obecny przy odsłonięciu pomnika Jana Karskiego - i, pośrednio, zasług polskiego państwa podziemnego dla Żydów - przy Muzeum Historii Żydów Polskich. Zignorował natomiast 70. rocznicę rozpoczęcia Akcji Reinhardt, czyli przemysłowej eksterminacji polskich Żydów. Nie pojawił się też na obchodach powstań w Treblince i Sobiborze (por. „Od Redakcji”, 2013, s. 11).

Patriotyczne „wzmożenia” zogniskowane wokół toposu polskiej pomocy Żydom mają charakter reaktywny, polegają na reakcji wywołanej akcją. Ich treścią jest odmowa konfrontacji z rzeczywistością na warunkach zewnętrznych wobec polskiej kultury dominującej. Na podstawie lektury dokumentów polskiego państwa podziemnego i rządu w Londynie wolno w ten sposób myśleć o narodzinach toposu w latach 1942-194364 w odpowiedzi na przedostające się z okupowanej Polski do opinii publicznej tzw. wolnego świata wiadomości o faktycznym położeniu Żydów i stosunku do nich populacji większościowej, w tym także agend polskiej konspiracji. Kolejne punkty szczytowe dyskursu pomocowego to rok 1946 z pogromem kieleckim, rok 1963, rok 1968 z Marcem i rok 1985 z paniką moralną wywołaną unaocznieniem panującego w Polsce antysemityzmu w filmie Shoah (por. Libionka, 2008a). We wszystkich wymienionych wyżej wypadkach bodźcem właściwym było konstatowanie za granicą istnienia antysemityzmu w Polsce, co odbierano jako nieuzasadnione, krzywdzące i niedopuszczalne ${ }^{65}$. U zarania ostatniej fali UPRŻ - strukturalnie identycznej - tkwi książka Sąsiedzi Jana Tomasza Grossa z roku 2000.

Przez kilka pierwszych lat po ogólnokrajowej debacie na temat Sąsiadów mogło się wydawać, że dominująca kultura większościowa dojrzała do rewizji własnych założeń opartych na przemocy i wykluczeniu, a w ślad za rewizją - do gruntownej przemiany. Jednakże rok 2005 - gdy do władzy doszła formacja szermująca hasłami powstania Polski z kolan i repolonizacji - z punktu widzenia państwowej polityki historycznej był otrząśnięciem się z szoku wywołanego widmem końca martyrologiczno-heroicznego paradygmatu nacjonalistycznego w ujęciu etniczno-religijnym. Stanowit reakcję, która nie skończyła się wraz z klęską wyborczą partii Prawo i Sprawiedliwość. Zniesienie blokad - np. w postaci wymogu prawdopodobieństwa - przynosi kolejne inicjatywy w dziele wytwarzania całkowicie życzeniowej wizji stosunku do Żydów przed wojną

63 Pierwotne brzmienie uchwały proponowane przez Prawo i Sprawiedliwość oraz wersja ostatecznie przyjęta przez Sejmową Komisję Kultury i Środków Przekazu: http://www.jewish.org.pl/index.php/pl/opinie-komentarze-mainmenu-62/5608-spor-o-treblink.html.

64 Polska pomoc Żydom oraz polsko-żydowskie braterstwo broni to toposy tyleż fałszywe, co eksploatowane przez polski rząd w Londynie już w okresie powstania w getcie warszawskim (por. Libionka, 2014).

65 W analizie struktury zjawiska czytamy: „Zarzuty dotyczące antysemityzmu spotykają się wśród Polaków z upartą próbą dowiedzenia, że problemem jest nie sam antysemityzm, ale właśnie wysuwanie go jako zarzutu, oskarża się więc oskarżających" (Snochowska-Gonzalez, 2013, s. 275). Przy czym jako oskarżenia oraz opinie ideologiczne, tendencyjne i wrogie postrzegane są także nienacechowane opisy czy konstatacje (por. Żukowski, 2012). 
i w czasie wojny. Pod tym względem przepaść między stanem badań a rzeczywistością wirtualną nie przestaje się powiększać. Co ciekawe, nasilające się idylliczno-anhelliczne autoreprezentacje grupy większościowej nie stają w sprzeczności z symbolicznym i aksjologicznym awansem marginalizowanego uprzednio etosu (reprezentowanego np. przez tzw. Żołnierzy Wyklętych), który w sposób najzupełniej otwarty deklarował i wdrażał prześladowania mniejszości. Żydów zaś traktował z pominięciem pośrednich form agresji, niosąc im śmierć.

Co zaś tyczy się reaktywnej struktury UPRŻ, o ile Sąsiedzi Grossa byli bodźcem punktowym i jednostkowym, o tyle następnie doszło do rozproszenia czy też rozmnożenia źródeł bodźców. Trwające w Polsce badania nad Zagładą, prowadzone przez przedstawicielki i przedstawicieli różnych dyscyplin i różnych ośrodków badawczych, można określić mianem bodźcowania permanentnego. Tłumaczyłoby ono intensywność i temperaturę emocjonalną obecnej fali UPRŻ, która przybrała formę reakcji wieloletniej ciągłej, trwającej już blisko dziesięć lat, jeśli za jej początek przyjąć rok 2005. Rzecz jasna, bodźcem pierwotnym, prowokacją źródłową jest Zagłada traktowana projekcyjnie i - tu zgadzam się ze Steinlaufem - „na płaszczyźnie emocjonalnej [...] przekształcona w niemiecko-żydowski spisek wymierzony przeciwko Polakom. [...] Znaczeniem Zagłady stało się prześladowanie Polaków przez Zagładę" (Steinlauf, 2001, s. 102) ${ }^{66}$. Przy czym nie chodzi tu o Zagładę jako fakt, lecz o Zagładę jako fakt społeczny - widzianą z perspektywy ofiar i badaczy niepodporządkowanych polskiej „frazie zobowiązania”67. W tym sensie status prześladowcy może zyskać każdy, kto w odniesieniu do Zagłady nie poczuwa się do lojalności względem polskiej narracji dominującej.

Z punktu widzenia kultury dominującej powyższa sfera zjawisk i zagadnień wymaga pacyfikacji, a co najmniej otoczenia „kordonem sanitarnym polskiej pamięci” - za sformułowaniem Jana Grabowskiego (por. Grabowski, 2014a). UPRŻ to mało skomplikowana blokada siłowa oparta na jawnym i otwartym zaprzeczaniu rzeczywistości. Istnieją też jednak strategie subtelniejsze, które polegają na uznaniu faktów, następnie zaś obstawieniu ich innymi faktami i wyprodukowaniu wizji przeszłości równoznacznej z neutralizacją, a niekiedy wręcz wykorzystaniem spraw najbardziej problematycznych dla wzmocnienia optyki większościowej. Mam tu na myśli „przyznawanie” czy „zwracanie” Holokaustu Żydom na warunkach symetrii prostej, czyli równoważności martyrologii polskiej i żydowskiej - z wyraźną tendencją do holokaustyzacji polskiego doświadczenia68. Z czasem holokaustyzacja prosta ustąpiła miejsca holokaustyzacji złożonej. Polskie cierpienie zaczęło być przedstawiane jako - jednocześnie - wcześniejsze niż Holokaust i trwające również po Holokauście, a także zawinione jakoby przez Żydów. W takim ujęciu większościowe polskie postawy i zachowania wobec Żydów są racjonalizowane

66 Moja zgoda nie obejmuje następującej po tym stwierdzeniu wykładni: „W tej niesamowitej wolcie rozpoznajemy pokłady niemożliwego do zaakceptowania ani przezwyciężenia poczucia winy Polaków związanego ze świadkowaniem Zagładzie" (Steinlauf, 2001, s. 102).

67 Na temat „fraz zobowiązań” (za Zatargiem Jean-François Lyotarda) oraz społecznej organizacji percepcji por. Tokarska-Bakir, 2012a.

68 Na temat holokaustyzacji por. Janicka, 2010. 
jako odpowiedź na okupację radziecką wschodnich terenów Drugiej Rzeczypospolitej, wywózki i Katyń (por. Janicka, 2014). Nadawany im jest charakter wtórny, reaktywny, a także walor działań prewencyjnych i samoobrony koniecznej przed tym, co miało nastąpić w 1944 i 1945 roku. Efektem konfiguracji tego typu - prócz racjonalizacji - jest także moralna legitymizacja wszystkiego, co nie daje się już ukryć.

\section{Trauma jako strategia przyswojenia}

Koncepcję polskiego doświadczenia Zagłady jako traumy postrzegam jako jedną ze strategii przyswojenia tego doświadczenia. Strategię bezpieczną, albowiem nienaruszającą warunków ramowych dyktowanych przez polską kulturę dominującą. Stało się mianowicie tak, że badacze pracujący w Polsce - czy na materiale pochodzącym z Polski - w większości nie podjęli próby konfrontacji i uzgodnienia narzędzi badawczych z przedmiotem badania. Akceptacja narzędzi składających się na paradygmat traumatyczny była przeważnie bezkrytyczna. Bezkrytyczny był stosunek do przedmiotu badania, czyli do opowieści i braku opowieści o Zagładzie. Kształt opowieści lub jej brak składano na karb traumy, najczęściej nie próbując mierzyć i problematyzować odstępu między reprezentacją faktów a tym, co wiadomo o faktach z różnorodnych źródeł. Zabrakło świadomości własnej pozycji i własnych założeń - szczególnie niezbędnej w sytuacji, gdy badaczce/badaczowi przychodzi wypowiadać się we własnej sprawie. (Nie, nie uważam, że jako uwikłani w polską kulturę dominującą powinniśmy wyłączyć się ze sprawy.)

W efekcie wymienionych zaniechań koncepcja polskiego doświadczenia Zagłady jako traumy stała się narzędziem - a jednocześnie pretekstem i uprawomocnieniem - dekontekstualizacji tego doświadczenia. Dyskurs traumy i kultury posttraumatycznej został wzmocniony z jednej strony opacznie zinterpretowaną Adornowską kategorią niewyrażalności i Celanowską kategorią milczenia, z drugiej zaś dyskursem pamięci rozumianej za Haydenem White'em jako „bunt przeciwko historii”, a za Frankiem Ankersmitem jako „przeciw-historia”. Dyskurs historii odrzucano - za White'em i Ankersmitem - jako domenę sensotwórczej przemocy spełniającej się w obsesyjnej potrzebie poznawczego uporządkowania i przyporządkowania, sprowadzania nieznanego do tego, co znane, odmawiającej wyjątkowości doświadczeniom jednostek i zbiorowości. Tyle tylko, że postulat ten został sformułowany w uniwersum euroatlantyckim, w którym piętnaście lat po wojnie ukazało się monumentalne dzieło Raula Hilberga Zagłada Żydów europejskich (1961) ${ }^{69}$ i nieustannie prowadzono krytykę opresyjnych wzorów kultury dominującej, dyskurs pamięci natomiast reprezentowały świadectwa ofiar i niedoszłych ofiar Zagłady. Siłą rzeczy znaczył on więc co innego niż w kontekście polskim, gdzie za świadectwa Zagłady uznano również teksty kultury produkowane przez grupę większo-

69 Wobec dzieła Hilberga formułowano np. zarzut dystansu skrywającego zaangażowanie autora ze szkodą dla materi wywodu. Krytykowano także pominięcie przez badacza głosu ofiar i przejęcie języka sprawców (por. Friedländer, 1993, ss. 130-134; LaCapra, 2001, ss. 100, 112).

SLH 3/4 2014/2015 | str. 187 
ściową, nie wnikając w różnicę statusu i usytuowania obu grup względem siebie oraz w stawki symboliczne zaangażowane w tworzenie polskiego obrazu Zagłady. Dodatkowo postulat White'a, Ankersmita czy LaCapry inaczej brzmiał w kraju, który do dzisiaj a minęło siedemdziesiąt lat od zakończenia Akcji Reinhardt - nie dopracował się historii zagłady Żydów polskich ${ }^{70}$. Równolegle zaś rygory pozytywistycznej historiografii nie stanęły na przeszkodzie wypełnianiu białych plam w zakresie martyrologii grupy większościowej, także w okresie, gdy istniała cenzura państwowa.

Zresztą docelowo nie tylko o historię zagłady Żydów polskich chodzi - Polska ma znakomite tradycje historiografii dziejów Żydów, skrupulatnie izolowanej przez większość od historiografii głównego nurtu. Znakiem realnej zmiany społeczno-kulturowej byłaby historia zintegrowana, czyli zastąpienie historii Polaków historią Polski, a tego nie da się zrobić z zachowaniem dotychczasowych większościowych wyobrażeń o wspólnocie, jej tożsamości i przeszłości. „Postulat ten zakłada wypracowanie takich ram i takich warunków opowieści, w których mogłaby zafunkcjonować historia różnych grup obywateli Rzeczypospolitej - w tym należących do mniejszości - jak dotąd pokrywana milczeniem, przyćmiewana, wchłaniana lub unieważniana przez dominujący dyskurs większościowy. Integracja historii mniejszości nie jest jednak możliwa bez integracji historii większości - ze wszystkim, co nie pasuje dzisiaj do obrazka” (Janicka, 2012, s. 473 ${ }^{71}$. Innymi słowy, tak zwanej wspólnej historii nie sposób napisać z pominięciem przemocy i wykluczenia aplikowanych mniejszości (mniejszościom) przez większość.

Wypowiedziany w Polsce postulat buntu przeciwko „wielkiej narracji” o Szoa - będącej domeną naukowej historiografii - był zatem nawoływaniem do odrzucenia czegoś, co nigdy w Polsce nie powstało (por. Dobroszycki, 1993) ${ }^{72}$, jak również tego, co zostato wypracowane poza Polską i nie zostało w Polsce przyjęte, a nawet przetłumaczone na język polski. Mam na myśli prace badaczek i badaczy zagłady polskich Żydów spoza Polski. „Przeciw-historię” i „bunt przeciwko historii” wartościowano jednoznacznie pozytywnie: jako gest antytotalitarny. Takie postawienie sprawy w kulturze podporządkowanej niemal bez reszty paradygmatowi antykomunistycznemu wprowadzało dodatkowo element szantażu emocjonalnego i równało się założeniu blokady percepcyjnej, chroniącej przed konfrontacją z - przyrastającą mimo wszystko - wiedzą rzeczową. Twierdzę, że w związku z tym koncepcja polskiego doświadczenia Zagłady jako

70 Nie mam tu na myśli szkicowego i skoncentrowanego na drugiej, przemysłowej fazie Zagłady artykułu Filipa Friedmana, szefa Centralnej Komisji Historycznej przy Centralnym Komitecie Żydów Polskich (por. Friedman, 1946). Trudno też za takie opracowanie uznać pracę Artura Eisenbacha Hitlerowska polityka zagłady Żydów (Eisenbach, 1961). Książka ta przynosi wzorową rekonstrukcję tytułowego zagadnienia. W opowieści Eisenbacha Zagłada jako niemiecka nazistowska zbrodnia państwowa odbywa się w próżni społecznej. Polacy wzmiankowani są jako ofiary niemieckiej nazistowskiej polityki oraz w kontekście świadczenia Żydom pomocy, a „Bliższe poznanie hitlerowskiej polityki wynarodowienia i wyniszczenia narodu polskiego pomaga lepiej zrozumieć politykę zagłady Żydów” (Eisenbach, 1961, s. 139). Wzmianka o tym, że „stosunek sanacyjnych kół rządzących do Żydów odbił się fatalnie na sytuacji w kraju i zaważył w pewnej mierze na losie ludności żydowskiej w Polsce” (Eisenbach, 1961, s. 128), skutkuje ograniczeniem zasięgu antysemityzmu w Polsce do sanacji oraz ulokowaniem przyczyn zjawiska poza Polską, jako że - jak pisze Eisenbach - „Rząd sanacyjny nie tylko w polityce wewnętrznej kopiował wzory hitlerowskie" (Eisenbach, 1961, s. 122).

71 Autorem postulatu historii zintegrowanej na polskim gruncie jest Feliks Tych (por. Tych, 1999, s. 144).

72 Pytanie o polską historiografię zagłady Żydów polskich zadał w 1986 roku, a później wytrwale ponawiał Jan Tomasz Gross (por. Gross, 1986). 
traumy - lokując się na przedłużeniu wcześniejszych strategii przyswojenia - umożliwiła ponowne odegranie spektaklu „nieświadomości świadomych”, czyli odtworzenie „rytuału totalnego zaskoczenia inteligencji polskiej” w latach 2000-2001 w związku z publikacją Sąsiadów Grossa ${ }^{73}$.

W imię obywania się bez nadrzędnych, uspójniających płaszczyzn znaczeniowych i w ramach tworzenia przeciwwagi dla dziejowości inwestowano w poetykę niedookreślenia tak w literaturze pięknej, jak w krytycznej refleksji nad literaturą i kulturą. Prawo obywatelstwa w dyskursie zachowały sformułowania opisujące Żydów jako osoby, które „pochłonął czas” - ewentualnie „los”, ewentualnie „katastrofa dziejowa” - z towarzyszeniem enigmatycznych i niejednokrotnie kunsztownych obrazów. Debata koncentrowała się wokót utworów takich, jak Początek Andrzeja Szczypiorskiego, Umschlagplatz Jarosława Marka Rymkiewicza, Weiser Dawidek Pawła Huellego, Prawiek i inne czasy Olgi Tokarczuk i całej tak zwanej literatury małych ojczyzn. Wielką kumulację, a zarazem podręcznikową aplikację teorii posttraumy przyniosły Tworki Marka Bieńczyka - autora zawodowo zajmującego się nauką o literaturze w Instytucie Badań Literackich Polskiej Akademii Nauk. Ów eksperyment na wizerunku grupy większościowej spotkał się z aplauzem jej elit. Pytanie o zasadność przeniesienia paradygmatu posttraumatycznego w inny kontekst i odniesienia go do grupy zewnętrznej wobec grupy ofiar - nie padło. Do publikowanych drukiem świadectw żydowskich na szerszą skalę nie zaglądano. Burzące spokój polskie głosy marginalizowano. Zasoby archiwalne leżały odłogiem. Nie podjęto wysiłku przetłumaczenia i opublikowania w Polsce prac historycznych mających w horyzoncie polskie doświadczenie Zagłady. Charakterystyczny dla poetyki traumatycznej i posttraumatycznej niedostatek artykulacyjny - zwany poetycko strefą niewypowiedzianego - obejmowat antysemityzm przedwojenny i powojenny oraz to, co dzisiaj określamy mianem obrzeży Zagłady (the margins of the Holocaust). W efekcie powstawały kolejne narcystyczne autoportrety kultury większościowej. W sztafecie pokoleń stawką polskiej opowieści o Zagładzie pozostawał wizerunek Polski i Polaków. W tym zakresie rok 1989 nie stanowit przełomu.

Niezależnie od zawłaszczenia traumy Zagłady przez grupę zewnętrzną wobec ofiar, w kontekście kultury polskiej ryzykowna potrafi być także interpretacja głosu ofiar przy użyciu teorii traumy. Na karb traumy ofiar łatwo bowiem złożyć artykulacyjne niedostatki w komunikatach formułowanych przez osoby poddane antysemickiej przemocy. Nie jest to reguła bezwyjątkowa. Zazwyczaj jednak im nadawca komunikatu bliższy kulturze dominującej większościowej czy bardziej od niej zależny, tym większe w jego opowieści deficyty artykulacji w punktach przecięcia żydowskiego losu z trajektorią grupy dominującej większościowej. Autorzy/autorki pomijają milczeniem albo stosują dyskretną ironię, albo też w inny sposób - zawsze niekonfrontacyjnie - sugerują istnienie

73 „Zaskoczenie to - warto dodać - powtórzyło się w roku 1968, 1985 przy okazji projekcji filmu Shoah Claude’a "Lanzmanna czy w roku 2000 w związku ze sprawą Jedwabnego. Za każdym razem było to «tak totalne zaskoczenie», że można by mówić wręcz o ponawianiu rytuału «tak totalnego zaskoczenia». Agnieszka Arnold, która ujawniła zbrodnię w Jedwabnem, określa to zjawisko ironicznym mianem «niepokalanego poczęcia polskich elit» [Janiszewski, 2008, s. 20]" (Janicka, 2008, s. 246). 
całego obszaru zjawisk związanych z „murem wokół muru”, czyli z antysemityzmem grupy większościowej. W przekazach tego typu:

„Informacje o losie i doświadczeniu dyskryminowanego są niejasne, istnieją na prawach aluzji, które trzeba dopiero rozszyfrowywać. Odnajdywanie i rozumienie tych śladów nie jest wcale łatwe, a ich rozpoznawanie nie narzuca się jako jedna z ważnych wykładni tekstu. Dzieje się tak, ponieważ aluzje dotyczące dyskryminacji pojawiają się na tle narracji dominującej o mocnych znaczeniach, które są wyraźne i czytelne oraz układają się w dobrze znaną całość. [...] Dysproporcja ta określa sposób istnienia opowieści o dyskryminowanych w kulturze polskiej. [...] Sens tak rozumianej historii pozostaje jasny jedynie dla zamkniętego kręgu osób o podobnych przeżyciach i nie przedostaje się do świadomości grupy dominującej" (Żukowski, 2014, s. 44).

Nie implikuje to monokauzalnego wyjaśnienia tego stanu rzeczy. O ile jednak trauma autorów/autorek pozostaje hipotetyczna, o tyle presja nieprzepracowanych wzorów kultury dominującej, pod którą się znajdowali i nadal znajdują, jest najzupełniej faktyczna. I ta właśnie presja znika z pola widzenia wraz z zastosowaniem koncepcji traktującej milczenie czy niedomówienie jako znaki traumy.

Koncepcja Zagłady jako traumy bywa stosowana w charakterze narzędzia pacyfikacji głosu ofiar także wówczas, gdy jest on głośny i wyraźny. Zdarzało się, że traumą „traktowano" pisarstwo Henryka Grynberga czy Idy Fink - autorów operujących na antypodach „strefy niewypowiedzianego" i artykulacyjnego niedostatku, detalicznie opisujących fakty i mechanizmy przemocy oraz wykluczenia zlokalizowane w samym centrum polskiej kultury. Jednakże przez zaporę percepcyjną, której najświeższą warstwę stanowiła teoria traumy i posttraumy, nie były w stanie przedrzeć się całościowe rozpoznania nie tylko Henryka Grynberga. W roku 2000 w warszawskim Klubie Księgarza miała miejsce dyskusja nad książką Icchaka Cukiermana Nadmiar pamięci. Gościem honorowym wieczoru i zarazem głównym dyskutantem był Władysław Bartoszewski - członek Żegoty, Sprawiedliwy wśród Narodów Świata, który Icchaka Cukiermana znał osobiście. Na moje pytanie o to, co Cukierman pisze na temat polskiego państwa podziemnego i stosunku Polaków do Zagłady, Bartoszewski odpowiedział, że Cukierman to człowiek głęboko zraniony, więc trzeba mu wybaczyć. Nie chcę przez to powiedzieć, że Icchak Cukierman nie był człowiekiem głęboko zranionym. Chodzi mi o to, że uraz i zranienie nie wykluczają przytomnej analizy i rzeczowej artykulacji. Nie wykluczają świadectwa. Nie unieważniają też spraw i pytań artykułowanych przez ofiary.

Tymczasem w ustach społecznego autorytetu - identyfikowanego w polskiej przestrzeni publicznej jako autorytet moralny - uraz i zranienie posłużyły za narzędzia personalizacji i psychologizacji, a w efekcie unieważnienia problemu. Sprawy systemowe przesłoniła „sprawa Cukiermana” - wytworzona ad hoc w pańskim geście okazania wspaniałomyślności człowiekowi cierpiącemu przez zwolnienie go z odpowiedzialności za słowo, choć on sam nie prosił o ulgowe traktowanie ani tym bardziej o litość. Mamy tu do czynienia z przemocą, jaką jest pozbawienie jednostki/grupy atrybutów podmiotowości i sprawczości całkowicie wbrew jej woli. Przemoc osiąga formę szczytową 
w zapewnieniu, że ewentualny bunt przeciwko ubezwłasnowolnieniu zostanie jednostce/grupie wybaczony, co de facto oznacza zapowiedź jego unieważnienia. Mowa tutaj o konkretnych ludziach. Nie chodzi mi jednak o personalia, lecz o prawidłowości systemowe. Stosowanie przemocy wynika z czystego sumienia oraz dobrego samopoczucia i dodatkowo je umacnia. Kultura przemocy i wykluczenia okazuje się jednocześnie elastyczna i autystyczna. Nie tylko unieważnia potencjalne przeszkody, ale też wychodzi z konfrontacji z nimi wzmocniona na poziomie konstrukcji nośnej, osiągając wyższe piętro homeostazy.

Traumatyczny i posttraumatyczny paradygmat opisu polskiego doświadczenia Zagłady - choć do dzisiaj niejednokrotnie afirmowany w polu akademickim i popularny w sferach inteligenckich - okazał się jednak zbyt słaby jako antidotum na systematycznie ujawnianą wiedzę rzeczową. Stąd w skali społecznej przywrócenie wypróbowanych narracji mocnych: autoafirmatywnych i ofensywnych. Zwolennicy podejścia psychologicznego i psychoanalitycznego byli skłonni widzieć w nich przejaw fetyszyzmu narracyjnego w rozumieniu Erica Santnera (por. Santner, 1992): opowieści o doznanym, prawdziwym cierpieniu, która jednocześnie jest symptomem wyparcia innej, trudniejszej traumy. Tymczasem to ta inna, trudniejsza trauma - zagrażająca konstrukcji i spójności zbiorowej tożsamości - miała wymagać przepracowania przede wszystkim. W polskim przypadku inną, trudniejszą traumą miałoby być polskie doświadczenie Zagłady. Taki jest zresztą punkt widzenia Michaela C. Steinlaufa, jeśli prawidłowo rekonstruuję jego wywód. Jest to punkt widzenia, który nie dopuszcza myśli o istnieniu pozytywnej korelacji między polskim doświadczeniem Zagłady a konstrukcją i spójnością zbiorowej tożsamości. Rozrysowana w czasie korelacja ta przypomina sprzężenie zwrotne: konstrukcja polskiej tożsamości większościowej zdeterminowała kształt większościowego polskiego doświadczenia Zagłady, które wpłynęło uspójniająco na polską tożsamość większościową i być może w ogóle uspójnienie polskiej tożsamości większościowej było jego treścią. W rezultacie uzyskaliśmy tożsamościowy order zamiast disorder, którego dopatrują się tu psychologia i psychoanaliza.

Innym jeszcze efektem omawianego podejścia stała się polityka traumatyczna: pożądanie, konstruowanie i konkurencyjne eksponowanie traum własnych, czyli niezwiązanych z Zagładą - a raczej może związanych z nią relacją przeciwstawienia i rywalizacji.

„Trauma» staje się pewną konwencją mówienia o sobie i swoim miejscu w świecie. Język ten nie wyraża rzeczywistego traumatycznego wydarzenia angażującego podmiot w dialektykę wyparcia i powrotu wypartego, lecz niejako pragnienie traumy, życzenie skonstruowania sobie traumatycznej przeszłości" (Ostolski, 2009, s. 71) ${ }^{74}$.

W tym ujęciu zasada czysto wymiecionych podwórek, czyli segregacja traum na „nasze i waszą”, to podstawa. „Nasze” traumy, mimo iż mogą wydawać się bledsze niż Holokaust, mają przewagę liczebną. Na liście traum polskich znajdują się bowiem: utrata idylli Drugiej Rzeczypospolitej, utrata idylli „kresowej”, Katyń w pakiecie z radzieckimi

74 Więcej na ten temat: Sznaider, 2011. 
wywózkami, powstanie warszawskie, los tzw. Żołnierzy Wyklętych - podszyte antysemickim mitem żydokomuny. Tak skonstruowana polityka traumatyczna oparta jest na dwóch zasadniczych, niewyartykułowanych założeniach. Pierwszym jest niemyślenie o Zagładzie jako polskiej traumie i - najchętniej - niemyślenie o Zagładzie w ogóle, niemożliwe z powodu czynników odbieranych jako zewnętrzne, jeśli nie wrogie („żydowski antypolonizm”, „terror poprawności politycznej” etc.). Założenie drugie to odmowa myślenia o Zagładzie jako polskiej traumie. Funkcja owych polskich traum nie jest defensywna - jak w fetyszyzmie narracyjnym - lecz ofensywna. Antysemicki rewers sprawia, że istota polityki traumatycznej - usilnie fabrykującej zbiorową fiksację na traumie/traumach - polega na dostarczaniu uzasadnień odmowy myślenia o Zagładzie jako polskiej traumie. Uzasadnianie to przebiega zaś w trybie oskarżenia.

\section{Polacy, Żydzi, komuniści}

Trzeci filar przedstawionej przez Michaela C. Steinlaufa koncepcji polskiego doświadczenia Zagłady jako traumy stanowi założenie, że Polacy nie mogli przepracować owej traumy - czyli przyswoić pamięci świadków Zagłady i pamięci o Zagładzie - ponieważ udaremnili im to komuniści. Polacy i Żydzi to kategorie osobne i przeciwstawne, które w kontekście Zagłady - a także polskiej kultury większościowej dominującej - nie wymagają uściśleń. O przynależności do kategorii „Żydzi” nie decyduje tutaj język, kultura, wyznanie, poczucie przynależności i tożsamości lub jego brak. Klasyfikacja ta odwołuje się do kryterium rasowego, które - mimo iż wszechstronnie bezpodstawne - w polskich realiach jest społeczno-kulturową rzeczywistością. „Wkraczamy tu w dziedzinę ubezwłasnowolnienia, «skoro o tym, kim jednostka jest lub kim mogłaby być, decyduje miejsce zajmowane w strukturze społecznej przez podobne jej osoby» (Goffman, 2007, s. 155), a ściślej osoby uznane za podobne do niej przez instancję rozstrzygającą, czyli dominującą większość. Odwołując się do terminów zewnętrznych wobec opisanego idiomu kulturowego, denotację kategorii «Żydzi» należy natomiast opisać jako: wszystkie osoby poddane antysemickiej przemocy - fizycznej i symbolicznej - bez względu na autoidentyfikację" (Janicka, 2013, s. 99). Polacy zaś to nie-Żydzi. Raz jeszcze: zakres tych pojęć i zasadność ich zastosowania w wywodzie Steinlaufa nie budzą wątpliwości.

Oto jednak obok Polaków i Żydów pojawia się trzecia grupa: komuniści - wyodrębniona na podstawie innego kryterium i pozostająca w niejasnym stosunku do dwóch pozostałych. W tym miejscu daje znać o sobie brak krytyki pojęcia, które ma za zadanie objaśniać rzeczywistość, samo jednak nie zostaje objaśnione i odgraniczone od mitu. Komuniści zostają w ostry sposób przeciwstawieni Polakom. Konceptualizacja oparta na rygorystycznym przeciwstawieniu tzw. władzy i tzw. narodu stanowiła normę poprawności politycznej w inteligenckich środowiskach opozycyjnych, z którymi Steinlauf miał do czynienia w czasie pobytów studyjnych w Polsce w latach osiemdziesiątych ubiegłego wieku. Zamiast funkcji opisowej termin „komuniści” pełnił funkcję wartościującą: dyskwalifikował moralnie i wykluczał poza obręb wspólnoty. Z jednej strony zatem

SLH 3/4 2014/2015 | str. 192 
autor podporządkowuje się środowiskowej normie. Z drugiej jednak daje wyraz świadomości, że dychotomia „komuniści (niesuwerenna władza PRL) - Polacy” nie opisuje adekwatnie rzeczywistości powojennej Polski:

„[J]ednoznaczne rozgraniczenie rządzących i rządzonych, oznaczające, że sfery «prywatna» $\mathrm{i}$ «oficjalna» były zawsze nieprzystawalne, stanowiłoby nadmierne uproszczenie. «Oficjalny» świat składał się przecież z kilku milionów urzędników, którzy zostali wychowani nie w jakimś radzieckim inkubatorze, tylko w Polsce przed wojną, w czasie wojny i po wojnie. Polska pod rządami komunistów nie była jedynie tworem radzieckich manipulacji, ale efektem współoddziaływania tychże manipulacji i specyficznych uwarunkowań polskiej historii. Rządzący i rządzeni w powojennej Polsce rzeczywiście różnili się od siebie, ale też wszyscy byli Polakami. Było to najbardziej widoczne [...] w odniesieniu do «kwestii żydowskiej» i pamięci Zagłady" (Steinlauf, 2001, s. 79).

Nie licząc „doradców radzieckich” w latach 1948-1956, niesuwerenną władzę PRL stanowili Polacy. Jedynie niektórzy spośród nich - skutecznie wyeliminowani w latach 1956-1968 - nie spełniali etniczno-religijnych kryteriów polskości. Po nieudanej próbie legitymizacji władzy w oparciu o marksizm-leninizm i marksistowski internacjonalizm w okresie stalinowskim formacja popaździernikowa sięgnęła po legitymację nacjonalistyczną (por. Zaremba, 2001). Ze społecznym sukcesem. Redefinicja wspólnoty i przejście od kategorii narodowych do kategorii obywatelskich oraz perspektywy społecznej do dzisiaj zresztą w Polsce nie nastąpiły.

Twierdzenie, że władza blokowała ekspresję i analizę polskiego doświadczenia Zagłady, opiera się na fałszywym wyobrażeniu na temat wpływów władzy w zakresie kształtowania zbiorowych potrzeb symbolicznych. Manipulacje propagandowe nie imały się na przykład oddolnej, pieczołowicie kultywowanej pamięci Katynia i powstania warszawskiego. Z Zagładą styczność mieli wszyscy. Z Katyniem i powstaniem warszawskim - stosunkowo nieliczni. Jednakże to Katyń i powstanie warszawskie uzyskaŁy status „naszej polskiej” traumy - wspólnej i realnej. Po roku 1956 kult powstania warszawskiego stał się legalny i z roku na rok potężniał. Z czasem żołnierze podziemia niepodległościowego - wyjąwszy jego nurty programowo antysemickie - stali się pełnoprawnymi członkami organizacji kombatanckich. O Katyniu natomiast w obszarze polityki historycznej - zamiast szerzyć tak zwane kłamstwo katyńskie - konsekwentnie milczano ${ }^{75}$.

Odgórne operacje na pamięci Zagłady po 1945 roku przeprowadzano w taki sposób, by nie naruszyć progu tolerancji większości. Wyobrażenie na ten temat daje fakt, że

75 W 1956 roku Władysław Gomułka dawał do zrozumienia, że władza jest świadoma prawdy o Katyniu, ale nie ma możliwości jej głosić: „[...] nawet gdybyśmy ustalili fakty i doszli do wniosku, do jakiego doszła komisja w USA, że sprawcami tych zbrodni są władze radzieckie - czy to rzeczywiście jest potrzebne dla nas, dla Polski, dla naszych stosunków. Czy jeszcze ten nowy cierń do tej cierniowej korony, którą myśmy byli otoczeni i narody radzieckie, czy to jest potrzebne i wskazane? Nie jest potrzebne, towarzysze, i nie jest wskazane" (Protokót rozmów I Sekretarza tow. Wiesława z przedstawicielami młodzieży, 29 października 1956, AAN, KC PZPR, 237/V-280, t. I, k. 25,26 - cyt. za:Zaremba, 2001, s. 253). Gomułka odnosił się do ustaleń komisji śledczej Kongresu USA, działającej od września 1951 roku pod kierunkiem przewodniczącego Izby Reprezentantów, Raya Madena. Efektem prac komisji było uznanie winy ZSRR i zalecenie władzom USA wniesienia skargi przeciw Moskwie do Międzynarodowego Trybunału Sprawiedliwości w Hadze oraz przedłożenia sprawy na forum ONZ. 
liczbę trzech milionów polskich ofiar wojny wymyślił ad hoc Jakub Berman ${ }^{76}$. Chodzito o zrównoważenie informacji, że w Zagładzie zginęły trzy miliony Żydów. Symetria w liczbach bezwzględnych - podobnie jak wszystkie rodzaje uniwersalizacji i polonizacja Zagłady - pozwalała zamaskować dysproporcję procentową strat. Członek stalinowskiego establishmentu znał swój kraj i kulturę dominującą, i zdawał sobie sprawę, że prawda godziłaby w rdzeń większościowej mentalności i emocjonalności w sposób, który - w odróżnieniu od reformy rolnej czy nacjonalizacji przemysłu - nie zjednałby władzy społecznego poparcia ${ }^{77}$.

„Komuniści oczywiście nie głosili hasła «Polska dla Polaków», deklarowali natomiast, iż «naród polski w wyniku wojny i zmian terytorialnych przekształca się z państwa wielonarodowościowego w państwo jednonarodowe» (Bierut w orędziu noworocznym 1946 r.), iż «Chcemy zbudować państwo jednonarodowe» (Gomułka w noworocznej wypowiedzi) [„Głos Ludu" z 1 stycznia 1946 roku]" (Kersten, 1993, ss. 34-35).

W wyraźny sposób obywateli polskich uznających się i uznawanych za Żydów spisano na straty po Październiku. Do 1956 roku władza, owszem, próbowała przeciwdziałać antysemityzmowi. Respektowała jednakże w tym względzie granice wytyczone przez kulturę i społeczeństwo. I tak na przykład w 1946 roku po pogromie kieleckim odstąpiono od uchwalenia, przygotowanego już, dekretu o zwalczaniu antysemityzmu.

Podobnie starano się jak najszybciej i bez rozgłosu zamykać powojenne procesy „za Żydów"78 - kosztem sądowych nierzetelności popełnianych na niekorzyść ofiar. Najbardziej znanym dzisiaj przypadkiem tego typu praktyk są procesy jedwabieńskie przeanalizowane przez Andrzeja Rzeplińskiego ${ }^{79}$. Ustalenia takich badaczy polskiego wymiaru sprawiedliwości z lat 1944-1956, jak Alina Skibińska czy Andrew Kornbluth, jedynie rozszerzają i ugruntowują ten obraz:

76 Liczba 6028000 obywateli polskich pojawia się w Sprawozdaniu w przedmiocie strat i szkód wojennych Polski w latach 1939-1945 opublikowanym w 1947 roku przez Biuro Odszkodowań Wojennych. „Biuro Odszkodowań Wojennych przy Prezydium Rady Ministrów ustaliło tę liczbę zgodnie z dyrektywą Jakuba Bermana, przekazaną 17 XII 1946 r. szefowi Biura Jerzemu Osieckiemu [por. Mateusz Gniazdowski, «Ustalić liczbę zabitych na 6 milionów ludzi». Dyrektywy Jakuba Bermana dla Biura Odszkodowań Wojennych przy Prezydium Rady Ministrów, «Polski Przegląd Dyplomatyczny» 2008, nr 1, s. 99-113]" (Chmielarz, 2009, s. 91).

77 „Bezpośrednio po wojnie program odbudowy i reform zapowiadany przez przywódców komunistycznych cieszył się do pewnego stopnia sympatią polskiego społeczeństwa, zwłaszcza robotników, chłopów i inteligencji” (Steinlauf, 2001, s. 60). Nie było to mało. Jedno zastrzeżenie wszelako wypowiadano wprost: „Chcemy demokracji, ale bez Żydów” (Sprawozdanie kierownika Warszawskiego Wojewódzkiego Wydziału Komunikacyjnego przy Warszawskim Wojewódzkim Komitecie PPR tow. Tomaszewskiego Stefana z wyjazdu do Dęblina w dniu 10-11 lipca 1946, cyt. za: Paczkowski, 1991, s. 109)

78 „Nie zrobiono nic, by doprowadzić do upubliczniania rozliczeń Polaków współpracujących z okupantem w prześladowaniach Żydów (procesy z tzw. dekretu sierpniowego), poprzestając na eksponowaniu roli PPR i GL w akcji pomocy Żydom" (Libionka, 2008a, s. 19).

79 W ekspertyzie procesów jedwabieńskich możemy przeczytać, że na poziomie Urzędów Bezpieczeństwa Publicznego oraz prokuratury i sądów - ze strony niektórych funkcjonariuszy, prokuratorów i sędziów - doszło do „niedopełnienia obowiązków wynikających z kodeksu postępowania karnego i przez to wyrządzenia szkody w interesie publicznym oraz w interesie osób pokrzywdzonych przez zaniechanie możliwych do przeprowadzenia i koniecznych czynności procesowych, w wyniku czego doprowadzili celowo do niewyświetlenia większości okoliczności ludobójczego aktu w Jedwabnem 10 lipca 1941 r., i w konsekwencji do uniknięcia w pełnym zakresie odpowiedzialności karnej przez sprawców tej zbrodni [...]. Bez wolnej prasy, w ówczesnych uwarunkowaniach ustrojowych powiodła się ta zmowa ubecko-prokuratorsko-sędziowska poważnie ograniczająca dojście do prawdy w sprawie ludobójczego aktu w Jedwabnem. Zawiedli w końcu sędziowie Sądu Najwyższego, którzy, nieuwikłani w lokalne, głęboko zakorzenione zależności i uprzedzenia antysemickie, mogli - i powinni - zapobiec powodzeniu tej zmowy. Tak się nie stało. Upływ czasu oraz obowiązek poszanowania fundamentalnej zasady prawa zakazującej sądzenia tej samej osoby prawomocnie już osądzonej za ten sam czyn pozbawiły ofiary i nas wszystkich szansy na poznanie prawdy o tej zbrodni w rzetelnym procesie sądowym" (Rzepliński, 2002, ss. 458-459). 
„[O]rzeczenia sądów z tego okresu wyglądają często jak apologie, w których pomniejsza się perfidię i premedytację, z jakimi popełniano zbrodnie, sceptycznie traktuje się dowody obciążające oskarżonych, a sprzyjające im wątpliwe zeznania bierze się za dobrą monetę i tworzy alternatywną historię okupacji, w której oskarżeni nie mają właściwie wpływu na wydarzenia" (Kornbluth, 2013, s. 167; por. także Skibińska, 2011a).

Kornbluth nie pisze tego wprost, ale jednym z czynników oporu mógł być fakt, że zbrodnie na Żydach osądzano na podstawie artykułów dekretu z 31 sierpnia 1944 roku o ściganiu i karaniu przypadków kolaboracji:

„Wszak wśród oskarżonych znalazło się wielu wysoko postawionych obywateli, co nie odpowiadało zresztą stereotypowi sprawcy jako kogoś z lumpenproletariatu czy marginesu; żaden z nich z pewnością nie przejawiał pronazistowskich sympatii ideologicznych. Jak się wydaje, żadna z popełnionych przez nich zbrodni nie miała ani wspomóc wroga, ani przedłużyć okupacji. [...] Biografie tych oskarżonych wskazują, że nie kierowali się oni konformizmem czy oportunizmem, lecz wiedli życie w myśl zasad patriotycznych" (Kornbluth, 2013, ss. 165-166).

Kornbluth kładzie to na karb nienawiści do Niemców i jednocześnie antysemityzmu, czyli - według niego - tego, co pozytywne i negatywne w nacjonalizmie polskim. Przypomina przedwojenną pobłażliwość wymiaru sprawiedliwości dla sprawców przemocy antysemickiej w latach 1935-1939 przy jednoczesnej bezwzględności wobec członkiń i członków mniejszości, skazywanych masowo a to za "nielojalność wobec państwa”, a to za „zniesławianie Narodu Polskiego”. Przypomina też wiodącą rolę uniwersyteckich wydziałów prawa w ruchu narodowo-radykalnym. Mimo ubolewań pojedynczych członków nowego establishmentu, na przykład Leona Chajna, władze powojenne nie starały się złamać środowiskowej solidarności sądownictwa cywilnego:

„Jak to możliwe, że w okresie wzmożonej stalinizacji nowy rząd nie potrafit wyegzekwować od sądów oczekiwanych rezultatów? [...] Tolerancja społeczeństwa miała [...] swoje granice, które władze, w pełni świadome swej niepopularności, respektowały. Zawsze były na przykład na tyle ostrożne, by nie dopuścić do jakichkolwiek podejrzeń o faworyzowanie Żydów. I nawet przy wymierzaniu kary niemieckim zbrodniarzom wojennym, kiedy trzeba było pociągnąć do odpowiedzialności Polaków oskarżonych o zbrodnie z okresu okupacji, władze wolały na ogół podtrzymywać swój surowy wizerunek, tolerując jednocześnie ciągłe łagodzenie wyroków" (Kornbluth, 2013, ss. 160-161).

Mimo to niejednokrotnie zdarzało się, że przekonanie o mitycznej żydowskiej mściwości - podbudowane antysemickim mitem żydokomuny - podzielali zarówno podsądni, jak i sami sądzący ${ }^{80}$. W rezultacie:

„W sprawach osób oskarżonych o zbrodnie na Żydach gołym okiem widać było niechęć ze strony sędziów wobec wydawania surowych wyroków na te [osoby - E.J.], których udział w zabójstwach uznano za «relatywnie niewielki». Ponadto «naciągali» oni werdykty, a przy wydawaniu wyroków rutynowo przytaczali okoliczności łagodzące. [...] Potwierdzenie wagi tych zbrodni byłoby równoznaczne z przyznaniem, że w czystkach etnicznych brali udział

80 Na temat mitu żydowskiej mściwości oraz tak zwanej nadreprezentacji w kontekście powojennego wymiaru sprawiedliwości poza Polską por. Legge, Jr., 2013, ss. 174, 178, 202. 
poważani członkowie wspólnoty, a w niektórych przypadkach całe społeczności. [...] W każdym razie wśród oskarżonych [...] ogromną większość stanowili zupełnie zwykli obywatele, którzy mogli liczyć na wsparcie i przychylne zeznania swoich współmieszkańców, co dowodzi, że zbrodnie, o jakie ich oskarżano, nie były powodem do odrzucenia przez społeczność" (Kornbluth, 2013, ss. 165-166).

Skądinąd Steinlauf ma świadomość bezsilności propagandy oficjalnej w konfrontacji z „propagandą nacjonalistycznego podziemia i znaczną częścią świadomości społecznej” w odniesieniu do Żydów i Zagłady (por. Steinlauf, 2001, s. 64). Mówi o rehabilitacji dyskursu nacjonalistycznego, a niekiedy wręcz szowinistycznego po Październiku 1956 roku (por. Steinlauf, 2001, s. 88), o powrocie do sfery publicznej języka narodowo-religijnego po roku 1968 (por. Steinlauf, 2001, s. 95). Pisze też, że „urzędowy sposób uporania się z pamięcią Zagłady musiał w końcu odpowiadać potrzebie zbiorowej" (Steinlauf, 2001, s. 90) oraz że „[k]ampania antysyjonistyczna nie rozgrywała się przecież w próżni, lecz w pełni korzystała ze stereotypów osadzonych w polskiej historii" (Steinlauf, 2001, s. 104). Ujawnia wreszcie porozumienie ponad podziałami w sprawie upamiętniania Zagłady stanowiące wspólny mianownik „skompromitowanego internacjonalizmu” i „języka patriotyczno-symboliczno-religijnego", który wkroczył w fazę bezprecedensowej ofensywy po wyborze Karola Wojtyły na papieża Kościoła rzymskokatolickiego:

„Oznaczało to dla Auschwitz [...] pojawienie się narracyjnego palimpsestu: nie odejście od dotychczasowej wersji wydarzeń, marginalizującej pamięć Żydów, lecz stworzenie nowej warstwy narracji, która tylko częściowo przykryła starą. Nowa warstwa znaczeń przejawiała się w obfitości uświęconych religijnie miejsc męczeństwa. [...] Aby dawać świadectwo «zwycięstwa prawdy i miłości», jak określił papież męczeństwo Maksymiliana Kolbego, i modlić się za «wszystkie ofiary» Auschwitz, w 1984 r. grupa karmelitanek przeniosła się do budynków sąsiadujących z obozem, a przed nową siedzibą ustawiła sześciometrowy krzyż" (Steinlauf, 2001, s. 133) ${ }^{81}$.

W efekcie symbiozy dyskursów i paradygmatów Auschwitz uczyniono miejscem, które „ledwo wspominało Żydów, nosiło natomiast ślady czterdziestu lat komunistycznego, a potem katolickiego upamiętniania zwieńczonego nowym dodatkiem: klasztorem i krzyżem" (Steinlauf, 2001, s. 134). Autor milczy jednakże na temat tego, że chrystianizację obozu rozpoczęła wizyta Jana Pawła II z mszą polową odprawioną na rampie w Birkenau 7 czerwca 1979 roku².

To więcej niż incydentalna niekonsekwencja. W tym punkcie szczególnie wyraziście daje o sobie znać - widoczna także w innych miejscach - strukturalna właściwość

81 Do miejsc, o których pisze Steinlauf, należała „cela, gdzie ojciec Maksymilian Kolbe czekał na śmierć, miejsce związane z pamięcią Edyty Stein, zamordowanej karmelitanki, która nawróciła się na katolicyzm z judaizmu; pokryta kulami Ściana Śmierci, przed którą rozstrzelano tysiące polskich więźniów. Miejsca te, położone niemal w całości w obrębie obozu pracy, oznaczone tablicami, a często też krzyżami i okryte kwiatami, nabrały znaczenia świątyń narodowych i stały się celem pielgrzymek i modlitw milionów Polaków” (Steinlauf, 2001, s. 133).

82 „O godz. 15.00 przekroczywszy słynną bramę obozową z napisem «Arbeit macht frei» (Praca czyni wolnym) Ojciec Święty nawiedził celę śmierci, w której zginął św. Maksymilian Maria Kolbe, złożył wieniec i krótko modlił się na dziedzińcu bloku 11, na którym rozstrzeliwano więźniów. Ok. godz. 15.50 odleciał śmigłowcem do Brzezinki, gdzie czekało nań ponad milion wiernych i 200 byłych więźniów obozów koncentracyjnych - kapłanów i biskupów, ubranych w czerwone ornaty. To oni koncelebrowali Mszę św. z Papieżem przy ołtarzu ustawionym na dawnej rampie obozowej” („Auschwitz-Birkenau”, b.d.). Przy ołtarzu powiewała biało-czerwona flaga. 
wywodu Steinlaufa, który budując koncepcję polskiego doświadczenia Zagłady jako traumy, jednocześnie zdaje się snuć alternatywną i sprzeczną z nią opowieść. Oto bowiem, obciążywszy komunistów - cokolwiek by to miało oznaczać - odpowiedzialnością za zablokowanie procesu przyswajania pamięci Zagłady przez Polaków, autor demontuje dychotomię, na której opiera się przedstawione przez niego rozpoznanie. Demontuje, a ściślej: na przemian stosuje ją i odstępuje od niej. W demontażu zaś posuwa się tak daleko, jak nikt przed nim. Dostrzega bowiem sytuację, w której w ramach obrony dobrego imienia Polski i Polaków po Marcu '68 władza gomułkowska publikuje w trzech językach obcych, z przeznaczeniem dla odbiorcy zagranicznego, książkę The Blood Shed Unites Us przygotowaną specjalnie w tym celu przez Władysława Bartoszewskiego na podstawie zbioru Ten jest z ojczyzny mojej, który zredagował wraz z Zofią Lewinówną i który miał dwa wydania polskie: pierwsze w roku 1966 i drugie, rozszerzone, w roku 1969:

„Władysław Bartoszewski, założyciel Żegoty, działacz katolicki, więziony w czasach stalinowskich, był zdecydowanym przeciwnikiem rządów komunistycznych. W 1963 r., aby obalić zachodni stereotyp Polaków współdziałających w mordowaniu Żydów, Bartoszewski wystosował apel za pośrednictwem krajowej katolickiej i emigracyjnej prasy o materiały dokumentujące polską pomoc dla Żydów w okresie wojny. Bartoszewski, który najwyraźniej nie doświadczyt takich trudności, jakie piętnaście lat wcześniej napotkał Michał Borwicz podczas gromadzenia tego rodzaju materiałów, zebrał i opracował tom relacji zatytułowany Ten jest z ojczyzny mojej, wydany dwukrotnie przez katolickie wydawnictwo Znak. Wkrótce cytowała go prasa rządowa, a w 1970 r. państwowe wydawnictwo Interpress wydało opartą na tych relacjach pracę Bartoszewskiego po angielsku, francusku i niemiecku. To chwilowe zbliżenie stanowisk dyktowanych zupełnie odmiennymi motywami (w latach 70. Bartoszewski znów stanie się w Polsce persona non grata) jest kolejnym znakiem tego, w jakim stopniu, w miarę jak pokolenie wojenne dochodziło do władzy, kwestie związane z polskim doświadczeniem Zagłady, i w istocie tylko te kwestie, zdolne były przekroczyć najbardziej zasadnicze podziały polityczne" (Steinlauf, 2001, s. 101) ) $^{83}$

Jest to zgodne z rozpoznaniami innych autorów. Jak pisze Zofia Wóycicka w recenzji Pamięci przyswojonej:

„wielu badaczy zajmujących się świadomością historyczną Polaków w czasach PRL dokonuje podziału na pamięć oficjalną, kreowaną i propagowaną przez komunistyczne władze, oraz pamięć nieoficjalną, przekazywaną głównie przez rodzinę i przyjaciół, a w późniejszym okresie również przez wydawnictwa drugiego obiegu. Jak zauważają owi badacze, w odniesieniu do niektórych wydarzeń, na przykład Paktu Ribbentrop-Mołotow, Katynia czy Powstania Warszawskiego obie interpretacje były całkowicie rozbieżne, przy innych zagadnieniach, na przykład w kwestiach dotyczących relacji polsko-żydowskich czy historii stosunków polsko-niemieckich różnice te były znacznie mniejsze" (Wóycicka, 2002, s. 176).

83 W środowiskach inteligenckich - np. polskiego PEN Clubu - zwykło się tłumaczyć Władysława Bartoszewskiego tym, że w swoich publikacjach z roku 1969 i 1970 mówił prawdę. Inny stosunek do prawdy miała wówczas Irena Sendlerowa: „W 1968 roku, w ogniu antysemickiej kampanii prasowej, o Jej czynach przypomniała sobie ówczesna władza. Zażądano, by opowiedziała o nich w audycji radiowej. Odmówiła. - Na wszystko jest właściwy czas i miejsce. Dziś przyzwoici ludzie nie rozprawiają o polskich zasługach wobec Żydów - powiedziała" (http://www. otwarta.org/index.php/irena-sendlerowa-nie-żyje/ - dostęp w lutym 2014). 
Obserwacje te potwierdzają spostrzeżenie poczynione przez Jana Tomasza Grossa w potowie lat osiemdziesiątych:

„Otóż pomimo upartych wysiłków zawładnięcia przeszłością i odebrania rządowi monopolu na historię Polski - wysiłków wzmagających się podczas wszystkich okresów samodzielnej aktywności społeczeństwa - nie wrócono nigdy do zagadnienia stosunków polsko-żydowskich podczas ostatniej wojny. Jest to jedyny ważny fragment dwudziestowiecznej historii Polski, o którym nie napisano ani na emigracji, ani w wydawnictwach podziemnych żadnego bodaj tekstu, który nie mógłby zostać opublikowany w obiegu oficjalnym. Cóż może być przyczyną tej niespotykanej zaiste zgodności opinii, jeśli nie rozpowszechnione wśród Polaków przekonanie, że sprawy te zostały już dostatecznie (i ostatecznie) - wyjaśnione?" (Gross, 1986)

Pamięciowa czy narracyjna dychotomia „komuniści - Polacy” zostaje przez Steinlaufa obalona, po czym pisze on we wstępie, że związane z Zagładą „zbiorowe dylematy psychologiczne i moralne, [...] które jak nigdzie indziej w powojennej Europie domagały się ujawnienia oraz długiej i nieuchronnie bolesnej analizy, były zamiast tego tłumio-

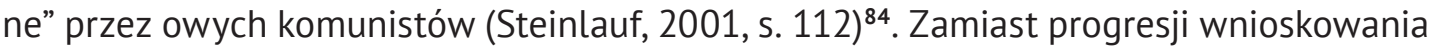
mamy zatem ruch wahadłowy: między suwerennymi rozpoznaniami badacza a bezrefleksyjnym i oderwanym od rzeczywistości paradygmatem antykomunistycznym, popularnym w środowisku polskiej inteligencji, której znaczący przedstawiciele posługiwali się w tym zakresie retoryką apokaliptycznej demonizacji i krucjaty moralnej ${ }^{85}$.

Niejasną pozycję względem Polaków, Żydów i komunistów zajmuje w książce Steinlaufa tak zwana żydokomuna. Badacz nie zastanawia się nad funkcjami mitu żydokomuny w polskiej narracji dominującej i konstrukcji polskiej tożsamości większościowej. Nie uwzględnia zatem na przykład faktu, że duża część polityki historycznej i działań symbolicznych władzy miała charakter polemiki z mitem żydokomuny. Mit żydokomuny był bowiem jednym z najgroźniejszych narzędzi delegitymizacji władzy. Autor raz traktuje ten konstrukt $w$ kategoriach zmistyfikowanego narzędzia opisu rzeczywistości (por. Steinlauf, 2001, ss. 65-66). W innym miejscu jednakże, gdy pisze o radzieckiej okupacji wschodnich ziem Drugiej Rzeczypospolitej po 17 września 1939 roku, traktuje żydokomunę jak realne zjawisko (por. Steinlauf, 2001, ss. 46-47). Czyni to, mimo iż

84 Dariusz Libionka datuje początki sojuszu wizerunkowego ponad podziałami na pierwszą połowę lat sześćdziesiątych i podkreśla, że uczestniczyły w nim również środowiska emigracyjne: „W maju 1963 r. apel Bartoszewskiego przedrukowała m.in. paryska «Kultura», w której kręgu rozważano również podjęcie pewnych strategii zmierzających do przezwyciężenia czarnego obrazu Polski w USA [Apel Władysława Bartoszewskiego, „Kultura” 1963, nr 5, s. 93-95]. Inicjatorem akcji był m.in. mieszkający w USA wybitny socjolog Aleksander Hertz” (Libionka, 2008a, s. 31).

85 Pojęcie krucjaty moralnej w tym kontekście stosuje Andrzej Walicki (por. Walicki, 2013, s. 203). Steinlauf trafnie rekonstruuje antykomunistyczny etos i otaczającą go atmosferę: „[Z]amiarem wroga dążącego do "sowietyzacji», jak to nazywał Michnik za Leszkiem Kołakowskim, było zniszczenie podstaw europejskiej cywilizacji w ogóle, a polskiej kultury w szczególności. Celem było przekształcenie Polaków «w ludzi o złamanych kręgosłupach, zniewolonych umysłach, zdewastowanych sumieniach... [którym] każda myśl o zmianie istniejącego stanu rzeczy wydawała się nieracjonalnym absurdem». Metodę tę realizowano dwustopniowo: pierwszym etapem było zniszczenie tradycji i zepchnięcie w niepamięć ogromnych obszarów polskiej przeszłości; drugim zastąpienie tradycji sfałszowanym wyobrażeniem przeszłości, a zatem i teraźniejszości, «wysterylizowaną» historią, której jedyną funkcją była legitymizacja istniejącego porządku" (Steinlauf, 2001, s. 110; cytaty wewnętrzne za: Michnik, 1977, ss. 116-119). Interesujące, że dewastacja sumień, fałszowanie wyobrażeń przeszłości i sterylizacja historii w odniesieniu do antysemityzmu jako integralnej części głównego nurtu kultury polskiej do dziś na próżno oczekują potępienia ze strony Adama Michnika. 
nieprawomocności takiego ujęcia skutecznie dowiedli wcześniej Jean-Charles Szurek i Paweł Korzec ${ }^{86}$ oraz Jan Tomasz Gross - odpowiednio w latach 1988 i 1993 (por. Szurek, 2010c; Gross, 1993). W jeszcze innym miejscu Steinlauf stara się doszukiwać w antysemickim micie przysłowiowego „ziarna prawdy” (por. Steinlauf, 2001, s. 65), nie bacząc na to, że w naukach społecznych przeważył pogląd, iż kategorie, za pomocą których stereotypizuje się daną grupę, mają źródło w grupie stereotypizującej ${ }^{87}$. Przestrogę przed mitem „ziarna prawdy” sformułowała Joanna Tokarska-Bakir:

„Mianem «ziarna prawdy» określam tyleż konieczny w myśleniu potocznym, co destrukcyjny w praktyce naukowej mechanizm pozornej weryfikacji kłopotliwych przekazów historycznych przed ich właściwym sproblematyzowaniem. Przejawem owego mechanizmu jest pospolite w myśleniu potocznym [...] domniemanie, że «coś było na rzeczy». W myśl zasady, sformułowanej przez Francisa Bacona w Novum Organum, stanowi ono próbę uniknięcia rzeczywistego wątpienia [por. Bacon, 1955]. [...] Z mechanizmu «ziarna prawdy» korzysta obficie inwersja projekcyjna, patologiczny mechanizm regulacyjny w stosunkach międzyetnicznych" (Tokarska-Bakir, 2008, ss. 71, 73).

W moim przekonaniu jedynym „ziarnem prawdy” w micie żydokomuny była i jest nadal wiara Polaków w jego prawdziwość ${ }^{88}$.

Do teorii „ziarna prawdy” Steinlauf jest tak dalece przywiązany, że stara się ocalić ją za wszelką cenę także tam, gdzie jest to najzupełniej beznadziejne i odbywa się kosztem ofiar:

„Od połowy lat 60. Moczar i jego zwolennicy zaczęli propagować obraz Polski znajdującej się pod ogniem zachodniej propagandy dotyczącej polskich postaw wobec Żydów w czasie wojny. [...] Jądrem prawdy w polskich zarzutach był zachodni stereotyp Polaka jako «wiecznego antysemity», który cieszył się z wymordowania Żydów na swojej ziemi. [...] Tego rodzaju przekonania, wynik traumatycznych wspomnień ofiar Zagłady, które współgrały z potrzebą zachodnich Żydów i zachodnich środków przekazu, zasługują na odrębną wnikliwą analizę. Dla naszych celów wystarczy, abyśmy zdali sobie sprawę z wyjątkowej wrażliwości Polaków na takie posądzenia" (Steinlauf, 2001, ss. 97-98).

Zasada „ziarna prawdy” zajmuje zatem pozycję nadrzędną względem faktycznej postaci rzeczy. Funkcję „ziarna prawdy” pełni tutaj zła opinia o Polakach denerwująca Polaków. Pytanie o jej zasadność zostaje niby to oddalone, de facto jednak autor dokonuje jego

86 Pierwsza wersja artykułu, powstała we współpracy z Pawłem Korcem, ukazała się w piśmie „Pardès” w 1988 roku (nr 8, s. 8-28). Steinlauf cytuje angielskie tłumaczenie tekstu Korca i Szurka Jews and Poles under Soviet Occupation (1939-1941). Conflicting Interests (Szurek, Korzec, 1989).

87 „Ponieważ Inny jest antytezą «ja», definicja Innego musi obejmować podstawowe kategorie, poprzez które definiowane jest «ja»" (Gilman, 1990a, s. 23 - przekład fragmentu Marcin Starnawski).

88 I tak na przykład cytuje, lecz pozostawia bez komentarza, list pasterski biskupów polskich ze stycznia 1991 roku z passusem: „Jesteśmy świadomi, że u wielu naszych rodaków żywa jest ciągle pamięć krzywd i niesprawiedliwości wyrządzonych przez powojenne rządy komunistyczne, w których uczestniczyli także ludzie pochodzenia żydowskiego. Przyznać jednak musimy, że źródłem inspiracji ich działania nie było zapewne ani ich pochodzenie, ani też ich religia, ale ideologia komunistyczna, od której sami Żydzi zresztą zaznali wiele niesprawiedliwości. Wyrażamy także szczere ubolewanie z powodu wszystkich wypadków antysemityzmu, które kiedykolwiek lub przez kogokolwiek na polskiej ziemi zostały dokonane" (Steinlauf, 2001, s. 152). Steinlauf pisze tylko, że list „potwierdzał po dwudziestu pięciu latach historyczne odwołanie przez II Sobór Watykański oskarżenia Żydów o bogobójstwo (Nostra Aetate)", choć autorytarna instytucja hierarchiczna nie działa w ten sposób, że niższe jej szczeble mają za zadanie potwierdzać - czy ratyfikować - decyzje podejmowane przez najwyższą władzę. Cały problem z Kościołem i chrześcijaństwem - sygnalizowany przez autora dorywczo i fragmentarycznie - pozostaje w gruncie rzeczy nienazwany. 
potrójnej dyskwalifikacji: przez złożenie - jak pisze - „stereotypu” na karb traumy ofiar (vide wypowiedź Bartoszewskiego o Cukiermanie) oraz ukazanie go w podwójnym splocie z interesami i manipulatorskimi intencjami czynników trzecich. To jedno z bardziej drastycznych zawęźleń wywodu Steinlaufa, który w innym miejscu tekstu reprezentuje zgoła odmienny pogląd, wyraźnie dystansując się od wiary w „rzekomy zachodni spisek zmierzający do obciążenia Polaków winą za Zagładę" (Steinlauf, 2001, s. 150).

Przywiązanie do teorii „ziarna prawdy” sprawia, że Steinlauf nie jest w stanie jasno orzec, że w społecznym odbiorze - w kategoriach emicznych - mit żydokomuny był twardym konkretem motywującym postawy i zachowania większości. Dzieje się tak, mimo iż autor opisuje ów mit $\mathrm{w}$ działaniu. Pisze o obozie internowania w Jabłonnie w 1920 roku (por. Steinlauf, 2001, s. 31) oraz zamordowaniu pierwszego prezydenta Drugiej Rzeczypospolitej Gabriela Narutowicza w roku 1922 (por. Steinlauf, 2001, s. 32). Gabriel Narutowicz został okrzyknięty „żydowskim prezydentem” przez prawicę i Kościół, które - w związku z jego wyborem na najwyższy urząd w państwie głosami posłów lewicy i mniejszości narodowych - zorganizowały kampanię nienawiści, a właściwie polowanie z nagonką. Natomiast internowanie w obozach odosobnienia żołnierzy, którzy stawili się, by bronić Polski przed wojskami Rosji Radzieckiej, a których wyodrębniono i uznano za potencjalną agenturę bolszewicką na podstawie adnotacji „mojżeszowe” w rubryce „wyznanie”, stanowiło opatrzenie mitu żydokomuny sankcją państwową ${ }^{89}$.

W tym punkcie można było powołać się na teorię form symbolicznych Ernsta Cassirera, z powodzeniem stosowaną przez badaczy także do historycznego opisu. W jej świetle z łatwością można wytłumaczyć, w jaki sposób mit żydokomuny - podobnie jak cały antysemityzm:

„[...] nie był bezpośrednią reakcją na realne okoliczności. Ludzie także nie reagują bezpośrednio na wydarzenia. W ramach procesu konceptualizacji i werbalizacji budują interpretację swojego przeżywania świata. I reagują tylko na tę stworzoną przez samych siebie koncepcję rzeczywistości. Każda interpretacja rzeczywistości jest samodzielnym, twórczym produktem ludzkiego ducha. Nierzadko oddziałuje silniej właśnie wtedy, gdy jest w całości lub po części fałszywa" (Volkov, 1995, s. 26 ) 90.

Steinlauf wykazuje opór przed jednoznacznym potraktowaniem żydokomuny jako antysemickiego mitu. W sukurs przychodzi mu strategia obiektywizmu rozumianego jako równy dystans do każdej ze stron. Żydokomuna zatem trochę mitem antysemickim jest, a trochę nie jest:

„Stosunki między Polakami i polskimi Żydami w okresie międzywojennym zaczęły się źle, a skończyły jeszcze gorzej. W dniu ogłoszenia niepodległości Polski w całym kraju wybuchły zamieszki antyżydowskie. [...] Zazwyczaj każda ze stron oskarżała Żydów o udzielanie pomocy drugiej stronie. $Z$ tych zamieszek zrodziło się przekonanie, które miało odegrać

89 Wbrew temu, co pisze Steinlauf, „incydent” ten nie jest w Polsce „powszechnie znany”.

90 W przypisie do tego fragmentu czytamy: „Tę tezę o ludzkim działaniu i myśleniu wyłożył wyczerpująco E. Cassirer, Die Philosophie der symbolischen Formen, 3 tomy, Berlin 1923-1929. W węższej formie teoria Cassirera została przedstawiona w: Language and Myth, Nowy Jork 1946. Zob. także S. Langer, Philosophy in a New Key, wyd. IV, Cambridge, Mass. 1960" (Volkov, 1995, s. 26, przyp. 50) 
znamienną rolę podczas II wojny światowej i po niej. Częściowo za sprawą antysemickiego stereotypu «Żyda-spiskowca», a częściowo za sprawą dużego udziału Żydów w różnego rodzaju komitetach «rewolucyjnych» $i$ «tymczasowych» tworzonych przez postępującą Armię Czerwoną, wśród Polaków narosło przekonanie, że wszyscy Żydzi byli zwolennikami Sowietów" (Steinlauf, 2001, s. 31).

Mit żydokomuny nie wziąt się z „zamieszek” w latach 1918-1919. Miał się on świetnie już w roku 1905, a korzeniami sięgał wiary w przyrodzone właściwości Żydów, wrogów Boga i porządku Bożego na ziemi, urodzonych spiskowców i rewolucjonistów na zgubę chrześcijaństwa. Mało tego, nie dowiadujemy się, jak wyglądał ów „duży udział Żydów w różnego rodzaju komitetach”. Jeżeli podobnie jak w latach 1939-1941 na zajętych przez ZSRR terenach Drugiej Rzeczypospolitej, to argument upada (por. Jasiewicz, 2001) ${ }^{91}$. Nie mówiąc o tym, że opcja na rzecz Rosji Radzieckiej czy później ZSRR była udziałem członków różnych dyskryminowanych grup i miała walor deklaracji niewiary w możliwość zreformowania kapitalizmu oraz kultury wykluczenia od środka, nie zaś żydowskiego przymierza z siłami diabła przeciwko Polsce - zarazem anielskiej i chrystusowej. W ujęciu mitycznym komunizm nie jest wyborem politycznym - dokonanym w sytuacji zablokowania pola politycznego, lecz czymś, co Żydzi robią Polakom (i w ogóle chrześcijanom) na mocy swojej natury: w akcie żydowskiej zdrady, niewdzięczności, zemsty czy perfidii - na przedłużeniu Ukrzyżowania. Jest to kolejny przypadek przedstawiania skutków jako przyczyn. Dodatkowo zaś mamy tutaj do czynienia z opisywaniem spowodowanych opresją wyborów, postaw i zachowań jednostek jako wynikających z wrodzonych cech ich grup odniesienia, czyli zjawiskiem, które Pierre Bourdieu nazwał paradygmatem wszelkiej rasistowskiej nienawiści (Bourdieu, 2006a, s. 105).

Na temat stosunku Żydów do niepodległości Polski Steinlauf wypowiada się bez skrępowania w filmie dokumentalnym Mariana Marzyńskiego Shtetl (1996). W książce jednak zupełnie nie rozwija tego wątku. W zamian odwraca porządek wynikania, co skutkuje udaremnieniem rozumienia i wymaga - znowu - wprowadzenia „argumentu” traumy:

„Podsycana poczuciem winy wrogość i agresja, z którą spotkali się Żydzi w powojennej Polsce, przyniosła w efekcie - gdy domknął się złowrogi cykl reakcji - jeszcze większe poczucie winy. Sttumienie tego nowego poczucia winy wymagało racjonalizacji nowej agresji poprzez dalsze powoływanie się na żydokomunę" (Steinlauf, 2001, s. 74).

Jeżeli antysemicki mit uznać za racjonalizację przemocy i zbrodni, oznacza to, że przemoc i zbrodnia miały miejsce na innym podłożu. W tym miejscu u Steinlaufa - niczym baśniowy środek magiczny (волшебное средство) w sytuacji bez wyjścia

91 Autor zdezawuował następnie wyniki swoich badań, przyjmując założenia i język antysemickiego paradygmatu: „Niestety myślę, że uległem wówczas pewnej modzie - że w dobrym tonie jest krytykować przedstawicieli własnego narodu. [...] Zrozumiałem, że przypadkowo znalazłem się po niewłaściwej stronie barykady. Szokujące bowiem dla mnie było, gdy moja znajoma, Żydówka, zafascynowana moimi prożydowskimi wywodami, usiłowała mnie zaprosić na spotkanie, na którym - jak to ujęła - różni ludzie mówią, jak powrócili do swoich żydowskich korzeni. Stąd nietrudno wywnioskować, że moje wywody sugerowały tzw. wrażliwość żydowską, a zatem budzenie się we mnie Żyda. Być Żydem to żaden wstyd, ale ja nim nie jestem, a ta konstatacja dość mocno mnie zreflektowała. Zwłaszcza gdy kolejny przedstawiciel tegoż narodu (pewnie kierując się podobną interpretacją moich poglądów) zaproponował mi napisanie artykułu o stosunku polskiego Kościoła do zagłady Żydów" (Jasiewicz, 2013, ss. 33-34). 
(por. V. I. Propp, 1969, ss. 43-48; polskie tłumaczenie: W. Propp, 1976, ss. 92-101) - pojawia się koncepcja traumy. Antysemityzm okazuje się naskórkowy, wtórny, nie zaś pierwotny. Jest racjonalizacją, nie zaś przyczyną przemocy i zbrodni. Konsekwencją takiego ujęcia jest zamknięcie obszaru dociekań niebezpiecznych dla konstrukcji nośnej kultury i tożsamości grupy dominującej.

\section{Polska trauma Zagłady jako hipoteza zaciemniająca}

Pora zadać pytanie o funkcje koncepcji traumatycznej na gruncie kultury polskiej i jej refleksji nad zagładą Żydów. Praca Steinlaufa jest z tego punktu widzenia przykładem szczególnie instruktywnym. Hipoteza traumy pojawia się w Pamięci nieprzyswojonej wszędzie tam, gdzie autor dochodzi do klarownego, zrozumiałego i możliwego do zweryfikowania opisu wydarzeń. I tak na przykład obraz roku 1968 - czytelny i opatrzony wystarczającymi wyjaśnieniami w przedmiocie genezy, mechanizmów i znaczenia - zostaje zagmatwany i zaciemniony hipotezą traumy. Oto Polacy jako rzekomo straumatyzowane Zagładą i

„bierne ofiary stają się czynnymi prześladowcami, zachowując przy tym własny obraz siebie jako ofiar. I w tym przypadku rozwiązanie to nie wymagało rozwoju żadnego nowego «totalizmu». Istniało bowiem zamrożone dziedzictwo, ponadczasowy i dostępny w każdej chwili model ekskluzywistycznego nacjonalizmu, ideologii przedwojennej endecji, model przewidujący określonych, odwiecznych wrogów: Niemców i Żydów. Wprawdzie w wyobraźni Polacy stali się ofiarami, ale rzeczywistość wskazywała na funkcjonowanie «przymusu powtarzania»: po raz kolejny prześladowano Żydów i co niezwykłe, w sposób przypominający ustawy norymberskie. [...] Piętnowano osoby mające żydowskich rodziców, a czasami nawet żydowskich dziadków, pradziadków lub współmałżonków, a oskarżeni często bronili się, próbując dowieść czystości krwi” (Steinlauf, 2001, ss. 102-103).

Tymczasem traumatyczny przymus powtarzania - tortura dla kogoś, kto istotnie był ofiarą - jest czymś zupełnie innym niż reprodukcja prosta wzoru kultury dominującej w wykonaniu przedstawicieli grupy większościowej. Steinlauf nie dopuszcza - a w każdym razie nie artykułuje - logicznej wątpliwości, że skoro wzór sprzed Zagłady funkcjonuje po Zagładzie, być może Zagłada nie stanowiła istotnej zmiany, punktu zwrotnego w kategoriach kultury dominującej, więc nie ma podstaw, by mówić w tym kontekście o traumie. Stąd wrażenie, że trauma jest jakością dodaną do rozumowania autora na siłę, i to taką, która neutralizuje jego przenikliwe rozpoznania i wyjaśnienia. O wydarzeniach 1968 czytamy też:

„W tej niesamowitej wolcie rozpoznajemy pokłady niemożliwego do zaakceptowania ani przezwyciężenia poczucia winy Polaków związanego ze świadkowaniem Zagładzie. Był to lęk najsilniej zakorzeniony właśnie w tych, którzy dorastali w czasach wojny, których poczucie tożsamości kształtowało się właśnie w tamtym okresie. Uraz ten, jątrzący się przez dwadzieścia lat, w sferze psychologicznej spychany do podświadomości, a w sferze politycznej nie dopuszczany do głosu w życiu publicznym, został teraz skanalizowany przez Moczara i jego zwolenników w system przekonań przeczący być może faktom, ale nie uczuciom" (Steinlauf, 2001, s. 102). 
Kolejne zaciemnienie związane z hipotezą traumy polega na wymiennym potraktowaniu podmiotów pamięci czy opowieści o Zagładzie. Zainspirowany najprawdopodobniej kategoryzacją Langera92, Steinlauf proponuje następującą periodyzację i zarazem typologię zjawiska: pamięć poraniona (1944-1948), pamięć stłumiona (1948-1968), pamięć wygnana (1968-1970), pamięć zrekonstruowana (1970-1989). Ostatnie ogniwo pamięć odzyskaną (1989-1995) - słusznie opatruje znakiem zapytania. Wszelako znak zapytania należy się już pamięci zrekonstruowanej (1970-1989). Tymczasem Steinlauf nie odnotowuje zmiany podmiotu pamięci, jaka dokonała się w konsekwencji czystki rasowej wdrożonej w roku 1968. Od lat siedemdziesiątych bowiem opowieść o Zagładzie jest - jak chce autor - „rekonstruowana” czy „odzyskiwana” przez grupę dominującą i na warunkach grupy dominującej. Nie znaczy to, że opowieść mniejszościowa kiedykolwiek wcześniej wybrzmiała na forum publicznym. Strategie tłumienia przekazu czy nawiązywania porozumienia z odbiorcą wtajemniczonym w sposób niedostrzegalny $z$ większościowego punktu widzenia były stosowane w komunikatach formułowanych w języku polskim przez niedoszłe ofiary Zagłady od samego początku. Odosobnione komunikaty wypowiadane pełnym głosem - jak to miało miejsce na przykład w wypadku Henryka Grynberga - neutralizowano w procesie recepcji, poddając je uniwersalizującym interpretacjom, abstrahującym od społeczno-kulturowego konkretu. Przymiotniki „poraniona”, „stłumiona”, „wygnana” odnoszą się do pamięci, której podmiotem jest grupa niedoszłych ofiar Zagłady. Do pamięci, jeśli nie wprost do jej nosicielek i nosicieli. Większość dominująca rozporządzała się opowieścią o Zagładzie w sposób bezceremonialny i dowolny, o ile tylko nie naruszało to jej dobrego samopoczucia.

Istotnym założeniem ramowym wywodu Steinlaufa jest zadeklarowane na początku dążenie do obiektywizmu. Nie jest to deklaracja naiwna. Konstrukcja kategorii obiektywizmu została przez autora starannie opisana z uwzględnieniem społeczno-kulturowych uwarunkowań. Autor zaprojektował ją jednak w taki sposób, by - posługując się pozorem symetrycznego potraktowania wykluczających się perspektyw - nie naruszyć uczuć wszystkich tych, którzy identyfikują się z perspektywą większościową:

„Naiwnością byłoby ignorować tożsamość dyskutantów. W większości przypadków strony sporu są oczywiste: Polacy kontra Żydzi, i jedni, i drudzy mają często własne doświadczenia związane z opisywanymi zdarzeniami. Prawda może leżeć gdzieś «pomiędzy», ale może też z równym prawdopodobieństwem znajdować się po jednej lub drugiej stronie czy jeszcze gdzieś indziej" (Steinlauf, 2001, s. 13).

Ostatecznie zaś badacz decyduje się na doprecyzowanie, które sugeruje, że nie ma to jak równy dystans do obu grup, gdyż - w domyśle - prawda leży jednak pośrodku:

92 Kolejne rozdziały książki Lawrence’a L. Langera Holocaust Testimonies. The Ruins of Memory noszą tytuły: Pamięc głęboka, Pamięć udręczona, Pamięć upokorzona, Pamięć skażona, Pamięć nieheroiczna (Langer, 1991). Przy czym Langerowi chodzi o rysy charakterystyczne - czy tryby - indywidualnych narracji żydowskich ofiar niemieckich nazistowskich obozów koncentracyjnych i zagłady. Langer analizował materiały zgromadzone w latach 1982-1989 w Fortunoff Video Archive for Holocaust Testimonies przy Uniwersytecie Yale. W zakres zainteresowania badacza nie wchodziły ani fakty historyczne, ani ich reprezentacja w historiografii czy dyskursie publicznym. Langerowska kategoryzacja nie ma zatem nic wspólnego z periodyzacją czy nawet typologią narracji. Poszczególne rysy czy tryby narracyjne mogą bowiem występować łącznie w opowieści jednego podmiotu. 
„Szczycę się tym, że Polacy uważają, iż jestem «prożydowski», a Żydzi, że «propolski»” (Steinlauf, 2001, s. 13). Fałszywa symetria polega tutaj na symetrycznym potraktowaniu doświadczeń i perspektyw, które nigdy nie były i nadal nie są symetryczne. Jest to konstrukcja par excellence przemocowa. Pominięcie asymetrii między grupą dominującą a grupą zdominowaną - konkretnie zaś: między grupą wywierającą przemoc a grupą będącą ofiarą przemocy - jest praktyką utrwalającą asymetrię. W wydaniu członków grupy zdominowanej praktyka ta oznacza de facto samoponiżenie i legitymizację systemu opresji.

Przyczyny takiego stanu rzeczy mogą być wyłącznie pozamerytoryczne, ponieważ autor dysponuje wiedzą i świadomością daleko wykraczającą poza to, co prezentowali w latach dziewięćdziesiątych najbardziej nawet krytyczni badacze kultury i historii Polski działający w Polsce. Przykładem jest to wszystko, co Steinlauf pisze na temat trzeciej fazy, czyli tzw. obrzeży Zagłady, które jako zjawisko i pole badawcze zostały odkryte w Polsce dopiero w latach dwutysięcznych. Przykładem może być także gruntownie uargumentowane rozpoznanie $w$ polskim państwie podziemnym pierwszej inkarnacji Polski dla Polaków. Steinlauf formułuje swój wniosek po rozpatrzeniu sytuacji w całej złożoności, nie pomijając żadnego argumentu, który zwykło się wysuwać na obronę polskiego państwa podziemnego i polskiej państwowości emigracyjnej. I tak pisze o rządzie londyńskim poddanym presji krajowej opinii, iż jest rządem żydowskim. Pisze jednocześnie o szczegółowych informacjach na temat Zagłady, wysyłanych przez polskie podziemie do rządu w Londynie, który następnie wiadomości te - jakkolwiek nie bez ociągania (por. Engel, 1987, 1993) - przekazywał dalej93:

„Polskie podziemie było zaangażowane w rozmaite działania polityczne, socjalne i militarne. Ale przy całej swojej wzorcowej demokratycznej strukturze i akcentowanej misji narodowej, a może właśnie z tego powodu, «państwo podziemne» przeznaczone było zasadniczo wyłącznie dla Polaków. [...] Silna więź ze społecznością, której broniło, oparta była na wspólnocie kulturowej i więzach krwi, nie na obywatelstwie. Więź ta sprawiała, że było ono wyrazicielem potocznych postaw, również wobec Żydów" (Steinlauf, 2001, s. 50) ${ }^{94}$.

Rozpoznanie to nadal stanowi tabu w narracji o historii Polski, w dalszym ciągu opowiadanej jako historia Polaków. Inna sprawa, że Steinlauf nie wyciąga z własnego

93 „Zarówno rząd na wygnaniu, jak i polskie podziemie opatrywały swe relacje o masowych rzeziach wyrazami oburzenia. [...] Czego brakowało w tych relacjach, poza nielicznymi wyjątkami, to apelu do Polaków, by pomagali Żydom. W polskiej prasie podziemnej wezwania do udzielenia Żydom pomocy były nie częstsze niż wyrazy potępienia dla antysemityzmu. Typową reakcją były spekulacje, czy Polacy będą następni w kolejce do wymordowania. Dla prasy podziemnej los Żydów znajdował się na odległym drugim planie w stosunku do losu Polaków" (Steinlauf, 2001, s. 51).

94 Steinlauf pisze o militarnym aspekcie stosunków ŻOB-AK, nie znając wszelako ich pełnego obrazu, jaki odsłoniła książka Barbary Engelking i Dariusza Libionki Żydzi w powstańczej Warszawie (Engelking \& Libionka, 2009). Według Steinlaufa utworzenie Żegoty - polsko-żydowskiej Rady Pomocy Żydom w ramach Delegatury Rządu - miało większe znaczenie niż pomoc militarna. W zdaniu tym można wyczytać krytyczne odniesienie do paradygmatu bohaterstwa, honoru i godnej śmierci - konstytutywnego dla Polski Walczącej. Na temat postrzegania spraw żydowskich w cywilnych i wojskowych pionach Polskiego Państwa Podziemnego, finansowania Żegoty najprawdopodobniej wyłącznie przez organizacje żydowskie, opóźnień w wypłacie funduszy, „wyparowania” ponad połowy środków przeznaczonych dla Żegoty i ŻKN por. Urynowicz, 2009. W czasach, gdy Michael C. Steinlauf pracował nad swoją książką, zagadnienie to - jakkolwiek w złagodzonej formie - omawiał Dariusz Stola w książce Nadzieja i zagłada. Ignacy Schwarzbart - żydowski przedstawiciel w Radzie Narodowej RP (1940-1945) (Stola, 1995). 
twierdzenia konsekwencji dla całokształtu wywodu, w którym rząd londyński, ZWZ-AK i Delegatura Rządu przedstawiane są jako znajdujące się poza wszelkim podejrzeniem, o ile chodzi o stosunek do Żydów (por. Libionka, 2006; Puławski, 2009).

Steinlauf na wylot zna „polskie argumenty obronne przywoływane przez pół wieku przeciwko świadectwom pamięci. Po pierwsze, jest tam przekonanie, że «zrobiliśmy co W naszej mocy, żeby im pomóc»; potem stwierdzenie «Czyż myśmy też nie cierpieli?»; i wreszcie gorzka «lekcja», przypominająca przekonanie Zofii Kossak: «Niezależnie od tego, co zrobimy, oni i tak nas nienawidzą»" (Steinlauf, 2001, s. 154). Podobnie nieomylnie autor identyfikuje większościowe polskie sposoby racjonalizowania, relatywizowania i unieważniania pytań związanych ze stosunkiem Polaków do zagłady Żydów. Jednym z takich chwytów jest pseudoargument, że za pomoc Żydom groziła w Polsce kara śmierci:

„A jednak tym, co ograniczało polską pomoc dla Żydów, nie był tylko strach przed karą śmierci. W okupowanej Polsce śmierć groziła za wiele wykroczeń, poważnych i drobnych, a czasami była tylko efektem znalezienia się na ulicy o niewłaściwej porze. Strach przed nią nie powstrzymał setek tysięcy Polaków przed przystąpieniem do ruchu oporu. To prawda, że ukrywanie Żydów było bardziej niebezpieczne niż kolportowanie podziemnej literatury. Przyczyny tej różnicy leżały jednak przede wszystkim w powszechnych postawach wobec Żydów, w wyniku których ktoś, kto ukrywał Żyda, mógł być znacznie mniej pewny swojego sąsiada niż osoba trudniąca się dystrybucją podziemnej prasy. Niesienie pomocy wymagało od ukrywającego czegoś więcej niż zwykłej odwagi i w takiej samej mierze jak współczucia trzeba było silnego własnego systemu wartości, niezależnego od norm społecznych. [...] Ta rzadka cecha pozwalała im stawić czoło nie tylko hitlerowskiemu terrorowi, ale też obojętności i wrogości dużej części własnego społeczeństwa” (Steinlauf, 2001, s. 54).

Steinlauf posuwa się zatem do wypowiedzi na temat nie tylko postaw dużej części spoŁeczeństwa, lecz także normy społecznej. Za Helen Fein (por. Fein, 1979, s. 33) podkreśla powszechność „przekonania, że Żydzi znajdują się poza zasięgiem sfery polskich zobowiązań, że - innymi słowy - nie są «swoi»" (Steinlauf, 2001, s. 54), choć nie precyzuje, że byli postrzegani nie tyle jako obcy, ile jako wróg. W tym momencie wydaje się zabierać głos z miejsca niepoddanego presji instytucjonalnej czy środowiskowym, towarzyskim lojalnościom.

Z drugiej strony jednak unika wszelkich stwierdzeń, które - mimo iż opisowe i nienacechowane - mogłyby zostać w Polsce odebrane jako tak zwane antypolskie. Konsekwentnie stosuje zatem techniki oszczędzające inteligencję polską ${ }^{95}$ i polski Kościót rzymskokatolicki. I tak np. w 1968 roku inteligencja milczy, Kościół zaś potępia antysemityzm na równi z „antypolską kampanią” za granicą (por. Steinlauf, 2001, s. 104) - bez słowa odautorskiego komentarza. W konkluzji rozdziału czytamy zaś, że szowinistyczny nacjonalizm szowinistycznym nacjonalizmem, jednak po upływie dekady z okładem miała w Polsce nadejść nowa epoka wraz z rewolucją „Solidarności” pod hasłami

95 Steinlauf zdaje się brać za dobrą monetę jej wysokie mniemanie o sobie samej, jakie przenika np. Rodowody niepokornych Bohdana Cywińskiego i charakteryzuje większość członków inteligenckiej formacji do dziś. W rezultacie inteligencja, jako nieproblematyczna, znika z badawczego horyzontu. 
„optymizmu, wspólnoty i pluralizmu” wraz z „próbą włączenia do zbiorowej polskiej pamięci obrazu pomordowanych Żydów" (Steinlauf, 2001, s. 105). Co robi ta konkluzja w rozdziale obejmującym okres 1968-1970? Czy informacja o wymuszonej emigracji 20 tysięcy „syjonistów” - czyli de facto wygnaniu Żydów z Polski - musi zostać zrównoważona optymistycznym akcentem za wszelką cenę i po co? Żeby czytelnikowi polskiemu nie było przykro? Pozamerytoryczny akcent optymistyczny - który można nazwać zasadą happy endu - to zresztą strukturalna właściwość wywodu Pamięci nieprzyswojonej.

Wywód Steinlaufa wydaje się rozpięty między dwoma zakazami: nie skłamać i prawdy nie powiedzieć - jak gdyby celem tekstu nie było opisanie polskiej pamięci Zagłady, lecz okazanie empatii (grzeczności?) polskiemu audytorium. Stoi za tym rozpoznanie polskiej kultury dominującej jako formacji obronnej, której agresja żywi się stale odnawianymi wyobrażeniami o rzekomych krzywdach. Rozpoznanie to - przyznam się podzielam. W warunkach, w jakich autor zdecydował się mówić, nie może ono jednak zostać wyrażone wprost, musi pozostać na poziomie niewyartykułowanych założeń tekstu. Tymczasem to ono tłumaczy wahadłową dynamikę wywodu Pamięci nieprzyswojonej. Objaśnia też niekoniecznie może zamierzoną, ale faktycznie zaciemniającą funkcję, jaką pełni w nim koncepcja polskiej traumy Zagłady. Steinlauf staje się w ten sposób tym, który legitymizuje i zaspokaja pragnienie większościowej kultury i społeczeństwa. Kultury i społeczeństwa obserwatorów uczestniczących, którzy chcą widzieć siebie jako bystanders czy onlookers: gapiów, przypadkowych świadków, postronnych obserwatorów zdarzenia niezależnego od siebie. Wytworem tej kultury i tego społeczeństwa jest marzenie o „zbawieniu przez traumę"96.

\section{Filozofia dialogu}

Pamięć nieprzyswojona to rodzaj operacji jednostronnie oszczędzającej, na którą składają się charakterystyczne praktyki dyskursywne. Ich analiza dostarcza odpowiedzi na pytanie o stawkę i cenę całego wywodu Michaela C. Steinlaufa. Jak już była o tym mowa, całość wywodu odznacza się dynamiką wahadła. Patronuje jej imperatyw swoiście rozumianego obiektywizmu. Do uprzywilejowanych praktyk dyskursywnych - prócz zasady happy endu - należy zaś przede wszystkim tworzenie wrażenia symetrii. Dodatkowo autor nie problematyzuje symetrii występującej niejednokrotnie w cytowanych przez niego wypowiedziach - np. w liście pasterskim biskupów polskich z 1991 roku (por. Steinlauf, 2001, ss. 151-152).

\footnotetext{
96 Parafrazuję tu zdanie Grzegorza Niziołka: „O zbawieniu przez traumę marzy społeczeństwo bystanders” (Niziołek, 2013, s. 35), kategorycznie nie zgadzając się przy tym na definicję polskiej większości jako bystanders. Niziołek z jednej strony przenikliwie dystansuje się od traumatycznego i posttraumatycznego paradygmatu opisu polskiego doświadczenia Zagłady: „Mówienie o polskiej kulturze w kategoriach reakcji posttraumatycznych może więc okazać się pułapką wyobrażeniowych iluzji i symbolicznych zadośćuczynień. [...] W ten sposób retoryka traumy wytwarza modele opisu dla doświadczeń, które w jej polu niekoniecznie się znajdują albo wręcz nie powinny się znaleźć” (Niziołek, 2013, ss. 74-75). Pisze też o zbiorowej „grze w grę zwaną «traumą»” (Niziołek, 2013, ss. 74-75). W innych fragmentach swej książki posługuje się jednak traumatycznym instrumentarium. Brak koncepcyjnej spójności (efekt pośpiechu wymuszonego ustawą o stopniach naukowych?) bywa dokuczliwy przy lekturze tej odkrywczej, nowatorskiej i doniosłej pracy.
} 
Treść owej symetrii stanowi komunikat: „Żydzi też nie byli bez winy”. Taką funkcję pełni informacja o demoralizacji Żydów oraz procedury zastosowane we fragmencie poświęconym okradaniu, wydawaniu na śmierć i mordowaniu Żydów przez Polaków w czasie Zagłady:

„Biorąc pod uwagę demoralizację znacznej części polskiego (i żydowskiego) społeczeństwa pod niemieckimi rządami, gwałtowny antysemityzm i zyski, jakie można było czerpać z Żydów, nie powinna nas dziwić powszechność donosów, szantaży, rabunków wszelkiego rodzaju oraz przypadków bezpośredniego mordowania Żydów. Ulice w «dzielnicach aryjskich» stały się terenem działania specjalnych gangów szantażystów (tak zwanych szmalcowników), którzy przyglądali się uważnie fizjonomiom i zachowaniom przechodniów w poszukiwaniu potencjalnej ofiary. W lasach chłopi pod eskortą Niemców lub z własnej inicjatywy polowali na Żydów, których zabijali na miejscu lub oddawali w ręce Niemców" (Steinlauf, 2001, s. 53).

Tu znowu mamy do czynienia z popularną figurą dyskursu większościowego, produkowanego i reprodukowanego przez członków inteligenckiej elity. Dziesięć lat później, odnosząc się do fałszerstwa historycznego na korzyść Polaków kosztem Żydów, jakim jest książka Kazimierza Moczarskiego Rozmowy z katem, Adam Michnik (historyk z wykształcenia) wywodził:

"[C]złowiek zapamiętuje często to, co lubi pamiętać, to, co krzepi jego serce. Dlatego w Rozmowach z katem Moczarski kreśli inny, szlachetny wizerunek Żydów i inny szlachetny wizerunek Polaków. Z najnowszych badań nad historią wiadomo, że oba te wizerunki są mocno wyidealizowane" (Michnik, 2008, s. 27) ${ }^{97}$.

Steinlauf sięgnął zatem po kliszę kultury dominującej. Trudno mówić o tym inaczej niż w kategoriach sugerowania symetrii za wszelką cenę - tam, gdzie jej nie ma. Po pierwsze bowiem, kondycja moralna okradanych, wydawanych na śmierć i mordowanych Żydów nie należy do tematu. (Jeżeli miałaby należeć, oznaczałoby to, że rabunek i zbrodnia popełniane przez Polaków na Żydach były czymś innym i zasługują na inne potraktowanie niż rabunek i zbrodnia.) Po drugie, „demoralizacja dużej części polskiego społeczeństwa" dotyczy stosunku Polaków do Żydów, podczas gdy do dzisiaj nic nie wiadomo na temat demoralizacji Żydów, która miałaby się przejawiać w sposobie, w jaki odnosili się w owym czasie do Polaków. Po trzecie wreszcie, fałszywa jest sama zasada uniwersalizacji - i generalnej, niezróżnicowanej oceny - przy partykularyzmie sytuacji, a w tym wypadku dodatkowo całkowitej niewspółmierności sytuacji porównywanych grup. Wtrącenie w nawiasie informacji o demoralizacji wielu Żydów sprawia, że przestajemy rozumieć, o czym właściwie mówimy - jak w potocznym powiedzeniu: „Ukradł czy jemu ukradli - jakkolwiek było, był zamieszany w kradzież".

Na tym jednak nie koniec. Dalej pisze bowiem Steinlauf:

97 W 2008 roku Kazimierz Moczarski zostat patronem nagrody „Gazety Wyborczej” w dziedzinie prac historycznych, mimo że charakter dokonanej przez niego manipulacji został przeanalizowany przez Michała Borwicza blisko trzydzieści lat wcześniej (Borwicz, 1980). Por. także Krupa, 2011. 
„Oczywiście nie tylko Żydów zdradzano. Pierwszy dowódca Armii Krajowej, gen. Stefan Grot-Rowecki został wydany Niemcom przez swojego oficera. Polowanie na Żydów było jednak łatwiejsze; wystarczyło mieć nosa, by ich «wyniuchać». Było też mniej niebezpieczne [...]" (Steinlauf, 2001, s. 53).

Porównanie to przede wszystkim przemyca sugestię własnej prawomocności: prawomocności aktu porównania. Jak gdyby istniały dwie równorzędne albo w jakimś sensie przynajmniej podobne konspiracje: polska i żydowska, działające w obliczu wspólnego wroga i we wspólnej lub podobnej sprawie. Nic tu się jednak nie zgadza. Polacy walczyli w sposób ogólnie przyjęty o cele polityczne czy tak zwane wyższe wartości. Żydzi w sposób nieuważany za walkę walczyli o życie w elementarnym rozumieniu tego słowa. Podstawą przynależności do polskiej konspiracji był światopogląd i wybór. Fakt konspiracji narażał Polaków na śmierć. W wypadku Żydów konspiracja była szansą na przetrwanie. Żydzi byli narażeni na śmierć przez sam fakt swojego istnienia. Tożsamość żydowska nie była kwestią wyboru. Żydzi mieli dwóch wrogów, z których w trzeciej fazie Zagłady - gdy ujmiemy rzecz statystycznie - Polacy byli wrogiem groźniejszym niż Niemcy. Żydzi konspirowali (się) nie mniej niż konspiracja polska, jeśli nie o wiele bardziej. Mimo to byli bardziej widoczni, skoro - jak pisze Steinlauf, posługując się popularnym polskim kolokwializmem - „wystarczyło mieć nosa, by ich «wyniuchać»”. Odmienny był bowiem stosunek większości do obu konspiracji. Nie mówiąc już o tym, że polska konspiracja była zamknięta dla Żydów i nie tylko w swoich odmianach niepodległościowych Żydów zazwyczaj prześladowała.

Wzmianka o Grocie-Roweckim w tym kontekście jest całkowicie nie na temat. Daje się jednak zrozumieć w porządku funkcjonalnym: w ramach tak zwanego dialogu polsko-żydowskiego. Polski rozmówca inteligencki, a także statystyczny Polak, w taki bowiem sposób reaguje na informacje o rabunku, polowaniu z nagonką, wydawaniu i wreszcie mordowaniu Żydów na obrzeżach Zagłady. Oto, co pisał na temat Jan Józef Lipski, jedna z najświatlejszych figur polskiej inteligencji liberalno-postępowej i polskiej opozycji demokratycznej:

„Przestępcy i amoralny margines istnieją niestety we wszystkich społecznościach, a jego ofiarą padli wówczas w Polsce nie tylko Żydzi, lecz i generał Grot-Rowecki, i tysiące innych żołnierzy konspiracji. Nieodpowiedzialne uogólnienia w tym przedmiocie mamy prawo odrzucić, tak jak winniśmy odrzucić uogólnienia krzywdzące inne narody. Antypolonizm nie jest moralnie niczym lepszym niż antysemityzm czy antyukrainizm" (Lipski, 1985, s. 114$)^{98}$.

Steinlauf nie myśli zatem wyprowadzać polskiego rozmówcy z błędu, przeciwnie: mówi jego językiem w trosce o jego samopoczucie. Jest to zarazem troska o to, by tak zwany dialog mógł toczyć się dalej. Ostatecznym wyciągnięciem ręki na zgodę jest wyrecytowanie - w konkluzji - formuły nieprawdziwej, lecz jakże miłej uchu polskiej większości:

98 Por. analiza wypowiedzi Lipskiego i innych luminarzy polskiej inteligencji liberalno-postępowej: Gross, 2007, ss. $15-46$. 
„Nie różniąc się pod tym względem od innych narodów pod okupacją hitlerowską, stali się oni [Polacy - E.J.] biernymi świadkami losu Żydów" (Steinlauf, 2001, s. 54).

Następnie pisze Steinlauf o trudnościach życia codziennego pod niemiecką okupacją, skrajnym terrorze, karze śmierci za pomoc Żydom oraz - to już coś niepopularnego wykluczeniu Żydów poza obręb wspólnoty. Natychmiast jednak dodaje: „Niemniej jednak Żydom w całej Polsce pomagały tysiące Polaków" (Steinlauf, 2001, s. 54), po czym następuje kolejne „niemniej jednak”. Efekt „niemniej jednak” wydaje się pełnić funkcję przysłowiowego leku na całe zło. Ostatecznie rozdział Polacy i Żydzi w czasie Zagłady 1939-1944 wybrzmiewa apologią Sprawiedliwych, którzy w Żydach zobaczyli, „niezależnie od historycznych obciążeń, istoty ludzkie potrzebujące pomocy" (Steinlauf, 2001, s. 54). „Nie donosicielstwo ani obojętność, ale istnienie takich właśnie osób jest jedną z najbardziej nadzwyczajnych cech polsko-żydowskich stosunków podczas Zagłady" (Steinlauf, 2001, s. 54). Powodzenie operacji podwójnego kodażu opiera się tu na polisemiczności przymiotnika „nadzwyczajny”, który może znaczyć zarówno „wspaniały”, „znakomity”, „świetny”, jak i „unikalny”, „nietypowy”, „niezwykle rzadki”9. Dzięki temu komunikat końcowy może zostać zaakceptowany zarówno przez odbiorców pozbawionych złudzeń co do sytuacji Żydów po tak zwanej aryjskiej stronie, jak i przez polską większość utożsamiającą się ze Sprawiedliwymi postrzeganymi jako jej reprezentanci.

Autor systematycznie ucieka się do przedstawiania skutku jako przyczyny lub do przedstawiania skutku z pominięciem przyczyny, dokładnie tak, jak czyni to polski dyskurs większościowy:

„Na przełomie stuleci wiele z życzliwości polskiej inteligencji wobec Żydów uleciało. Stosunkowo niewielu Żydów zdecydowało się zasymilować z polską kulturą i stać się «dobrymi Polakami». [...] Co gorsza, w nowych pokoleniach wykształconych Żydów, nawet jeśli asymilacja społeczna przebiegała bez zakłóceń, ideologia asymilacji wychodziła z mody" (Steinlauf, 2001, s. 24).

Ani słowa o przyczynie tego stanu rzeczy, czyli antysemityzmie polskiej inteligencji. Cienia refleksji na temat sensu asymilacji Żydów do kultury antysemickiej. Ani słowa o podwójnym wiązaniu (double bind), które Sander L. Gilman opisuje jako formułowanie wobec grupy opresjonowanej oczekiwań, których spełnienie zostaje następnie skrupulatnie udaremnione przez grupę opresjonującą, formułującą owe oczekiwania ${ }^{100}$. 0 „narastającej wrogości Polaków w stosunku do Żydów, nawet tych zasymilowanych" (Steinlauf, 2001, s. 29) przeczytamy w innym miejscu, w odniesieniu do epoki późniejszej,

99 W oryginale czytamy: „Not the informing or the indifference, but the existence of such individuals is one of the most remarkable features of Polish-Jewish relations during the Holocaust" (Steinlauf, 1997, s. 42).

100 "On the one hand is the liberal fantasy that anyone is welcome to share in the power of the reference group if he abides by the rules that define that group. But these rules are the very definition of the Other. The Other compromises precisely those who are not permitted to share power within society. Thus outsiders hear an answer from their fantasy: Become like us - abandon your difference - and you may be one with us. On the other hand is the hidden qualification of the internalized reference group, the conservative curse: The more you are like me, the more I know the true value of my power, which you wish to share, and the more I am aware that you are but a shoddy counterfeit, an outsider" (Gilman, 1990b, s. 2). Na temat kategorii podwójnego wiązania por. także Sluzki \& Ransom, 1976. Całość przypisu zawdzięczam Annie Zawadzkiej. 
mając w pamięci, że - tak czy owak - Żydzi byli mocno na bakier z asymilacją, która szybko „wyszła u nich z mody”.

Dalej jako pozbawione związku albo paradoksalne przedstawia Steinlauf to, co pozostaje w korelacji pozytywnej, wręcz w stosunku wynikania:

„Niemniej jednak, niezależnie od oficjalnego [złego - E.J.] nastawienia, a nawet w miarę jak Żydzi w Polsce zaczęli w pełni swobodnie posługiwać się językiem polskim, a w niektórych kręgach nawet porzucali język jidysz, w coraz większym stopniu określali samych siebie jako osoby «narodowości żydowskiej»” (Steinlauf, 2001, s. 29).

Nie dowiadujemy się, że proces ten był wynikiem rozpoznania reguł kultury, która nakładała na Żydów double bind. Rozpoznaniu zaś towarzyszyła odmowa uczestnictwa w systemie przymuszającym do samoopresji i samoponiżenia. Przyjęta zasada wahadła, nakazuje Steinlaufowi zakończyć i tę część wywodu akcentem pozytywnym. W rezultacie omawiany akapit znajduje się w efektownej klamrze, w ramach której na wstępie dowiadujemy się, że

„kolejne rządy w Polsce, włącznie z Sanacją, systematycznie odrzucały żądania oparte na żydowskich prawach narodowych. Tak więc, chociaż traktat [mniejszościowy, zwany małym traktatem wersalskim - E.J.] przewidywał tworzenie szkół żydowskich wspieranych przez państwo, polskie rządy nie chciały ich finansować i odmawiały akredytacji” (Steinlauf, 2001, s. 29).

Steinlauf oszczędza nam w tym miejscu informacji o rozlewie krwi, w tym na przykład o doświadczeniach Maxa Weinreicha (Por. Dawidowicz, 2008, ss. 168-169)101. To, o czym pisze, jest już dostatecznie „kontrowersyjne”, jak zwykli mawiać zwolennicy tak zwanego polsko-żydowskiego dialogu. Jeżeli jednak wytrzymamy do końca „kontrowersyjnego" akapitu, otrzymamy w nagrodę miłe tzw. polskiemu uchu zapewnienie:

„Nowa tożsamość żydowska kształtowała się jednak także dzięki możności rozwijania własnej kultury i instytucji w warunkach, które były znacznie bardziej obiecujące niż cokolwiek, co było im dostępne za cara" (Steinlauf, 2001, s. 29).

Autowizerunek i dobre samopoczucie grupy dominującej zostają uratowane. Nie po raz pierwszy i nie po raz ostatni.

Kolejne techniki to wygłaszanie sprzecznych - a przynajmniej niespójnych i nieuzgodnionych - opinii o charakterze podsumowującym jak ta, że w czerpanie zysków z Żydów - ze szmuglu, szantaży i donosów - „zaangażowanych było stosunkowo niewielu Polaków” (Steinlauf, 2001, s. 45) i ta o „powszechności donosów, szantaży, rabunków wszelkiego rodzaju oraz przypadków bezpośredniego mordowania Żydów" (s. 53). Wymienić należałoby także rozpraszanie informacji - jak w wypadku wszystkiego, co

101 Max Weinreich byt językoznawcą, twórcą podstaw filologii języka jidysz, współzałożycielem Żydowskiego Instytutu Historycznego (YIVO) w Wilnie. Podczas zamieszek antysemickich w listopadzie 1931 roku został trafiony kamieniem w głowę, wskutek czego stracit wzrok w jednym oku. W tym samym roku - w trakcie egzaminów maturalnych - władze zlikwidowały żydowskie seminarium nauczycielskie, gdzie pracował. Opowieści o permanentnych szykanach instytucjonalnych i braku fizycznego bezpieczeństwa, z czym pedagodzy i studenci musieli konfrontować się przez dziesięć lat istnienia placówki, wysłuchałam z ust Belli Szwarcman-Czarnoty, której rodzice byli uczniami Weinreicha tamże. 
dotyczy chrześcijaństwa i Kościoła, w szczególności rzymskokatolickiego. Następnie zaś powstrzymywanie się od analizy informacji i/lub opatrywanie ich niezrozumiałymi zastrzeżeniami, w ślad za czym idzie unieważnianie owych zastrzeżeń (podwójne zagmatwanie). Dobrym przykładem jest tutaj sposób przedstawienia listu duszpasterskiego prymasa Polski z roku 1936. W tekście głównym Steinlauf pisze, że Kościół potępiał nienawiść i przemoc skierowane przeciwko Żydom. W przypisie natomiast czytamy:

„zdecydowanie antysemickie stanowisko polskiego Kościoła w tym okresie pokazuje, że jego nauki nie stanowiły wyjątku, lecz były całkowicie zgodne z postawą Kościoła w innych krajach Europy i z retoryką Watykanu. Niemniej jednak nigdzie indziej Kościół nie miał do czynienia z 3,5 mln Żydów" (Steinlauf, 2001, s. 36, przypis 35).

Skoro list Hlonda był protestem przeciwko antysemickiej nienawiści i przemocy, skąd przypis o antysemityzmie Kościoła? Ostatnie zdanie przytoczonego fragmentu może służyć jako modelowy przykład podwójnego kodażu. Zawarta w nim informacja może zostać odczytana na dwa wykluczające się sposoby w zależności od kontekstu odbiorczego. W kontekście odbiorczym mniejszościowym będzie to dodatkowe obciążenie polskiego Kościoła społeczną nieodpowiedzialnością na kolosalną skalę. W kontekście odbiorczym większościowym będzie to nie tylko wytłumaczenie, lecz także usprawiedliwienie kościelnego antysemityzmu liczbą Żydów odbieraną jako nadmiar - zawsze, a co dopiero w wypadku 3,5 miliona. Angielskie sformułowanie brzmi zresztą bardzo mocno: „But nowhere else in Europe did the Church confront 3.5 million Jews” (Steinlauf, 1997, s. 151). Do konfliktu perspektyw jednakże nie dochodzi. Zarówno mniejszość, jak i większość mają możliwość uważać, że autor reprezentuje właśnie jej punkt widzenia. Efekt „niemniej jednak” to poniekąd znak firmowy całego wywodu Steinlaufa.

Mimo to Steinlauf mówi o wiele więcej niż większość, którą chce uważać za partnera rozmowy, jest w stanie przyjąć do wiadomości, a co dopiero zaakceptować. Nie do zaakceptowania z perspektywy większościowej są na przykład słowa o charakteryzującym kulturę i społeczeństwo Drugiej Rzeczypospolitej antysemickim opętaniu (sic!) podbudowane celnym rozpoznaniem:

„Sprawa ta, wywodząc się z najbardziej fundamentalnych problemów kształtowania się polskiej tożsamości narodowej, utrudniała jasne dostrzeganie tych problemów oraz autentycznie niepokojących zjawisk, które miały miejsce tuż za granicami Polski” (Steinlauf, 2001, s. 34$)^{102}$.

Wymienione i opisane powyżej chwyty konstrukcyjne są niezbędne, by zaniepokojony czytelnik uspokoił się i utwierdził w przekonaniu, że ostatecznie polska tożsamość narodowa jest w porządku, Żydzi też nie byli bez winy, a prawda leży pośrodku.

Praktyki dyskursywne, z którymi mamy do czynienia w Pamięci nieprzyswojonej, to swego rodzaju strategie czy techniki jednostronnie obowiązujące w polu tak zwanego dialogu polsko-żydowskiego. Zasady owego dialogu byłyby takie, że - to kolejny

102 Podobne rozpoznanie wniósł Czesław Miłosz, pisząc o „polskich antysemickich obsesjach, które sięgały psychozy, a w późnych latach trzydziestych wręcz obłędu, uniemożliwiającego jasne uświadomienie sobie niebezpieczeństwa wojny" (Miłosz, 1999, s. 273). 
przykład zaczerpnięty z książki Steinlaufa - Norman Davies nie musi się hamować przed wygłaszaniem antysemickich sądów, które skądinąd uchodzą w Polsce za nienacechowane wypowiedzi eksperckie. Michael C. Steinlauf natomiast musi się hamować przed nazwaniem sądów Daviesa antysemickimi. W związku z tym o samym Daviesie pisze: „Ten skądinąd znakomity historyk jest, niestety, niekompetentny w sprawach dotyczących polskich Żydów" (Steinlauf, 2001, s. 34, przypis 3). Innymi słowy, Davies nie musi dbać o dobre samopoczucie Steinlaufa, Steinlauf o dobre samopoczucie Daviesa i jego polskich czytelników - musi.

Regułę tę rozpoznał Erving Goffman, prowadząc studia nad piętnem, a ściślej nad stosunkami między piętnującymi a piętnowanymi. Badacz zauważył, że do obowiązków nosicieli piętna zalicza się okazywanie troski „normalsom”:

„Na lekceważenie, afronty i nietaktowne uwagi nie powinno się odpowiadać tym samym. [...] Kiedy osoba z piętnem odkrywa, że normalsi mają problemy z ignorowaniem jej ułomności, powinna spróbować im pomóc, świadomie redukując napięcie. W tych okolicznościach nosiciel piętna może na przykład próbować przełamywać lody, otwarcie odnosząc się do swojej ułomności w sposób, który pokazuje, że jest on obiektywny i potrafi przyjąć swój stan bez trudu" (Goffman, 2007, s. 159).

Zaobserwowane procedury dyskursywne istotnie wydają się pełnić funkcję samoograniczników:

„aby normalsi nie zostali postawieni w sytuacji, w której okazanie akceptacji nie jest tatwe lub, co gorsza, jest po prostu bardzo trudne. Od nosicieli piętna taktownie się oczekuje, że będą dobrze wychowani i nie będą nadużywać swojego szczęścia. Nie powinni testować granic okazywanej im akceptacji ani czynić z niej podstawy do kolejnych roszczeń. [...] Wyraźnie widać teraz naturę dobrego przystosowania. Wymaga ono, aby nosiciel piętna radośnie i bez samoświadomości akceptował siebie jako osobę zasadniczo taką samą jak każdy normals, jednocześnie nie dopuszczając dobrowolnie do sytuacji, w których normalsi mieliby trudność z werbalnym potwierdzeniem jego akceptacji jako normalsa. [...] Złudna akceptacja może w ten sposób być podstawą złudnej normalności" (Goffman, 2007, ss. 164-165; podkreślenia autora).

Kodeks postępowania obligujący nosiciela piętna do ochrony normalsów to jedynie pozorne odwrócenie ról i złudne postawienie nosicieli piętna w sytuacji nadrzędnej. Podobnie jak pozostałe wytyczne przystosowania jest on bowiem „inspirowany przez normalsów" (Goffman, 2007, s. 162). Stawkę rozgrywki stanowi zaś zachowanie ustanowionego przez „normalsów” status quo oraz to, by mogli oni pozostać „względnie niezagrożeni w swoich przekonaniach tożsamościowych" (Goffman, 2007, s. 164).

Z dialogiem rozumianym jako partnerska rozmowa, w której „ty” i „ja” to pozycje przechodnie, nie ma to nic wspólnego. Z trudem można mówić tutaj również o wyjaśnianiu i rozumieniu czy o poznaniu. Stawką wywodu Steinlaufa nie jest bowiem to, by odpowiednie dać rzeczy słowo, lecz to, w jaki sposób nie urazić kultury dominującej, a jednocześnie nie przyjąć jej perspektywy za swoją. I tak na przykład nie dekonstruuje on i nie odrzuca zasady symetrii, która jest jednym z podstawowych wymogów etykiety

SLH 3/4 2014/2015 | str. 212 
ustanowionej jednostronnie przez Polaków i obowiązującej w kontrolowanym przez nich polu tak zwanego dialogu polsko-żydowskiego. Próbuje natomiast dowieść dobrej woli, radząc sobie z nią w inny sposób. Aby zbliżyć się do konstrukcji symetrycznej, obciąża Żydów, na ile nie wymaga to od niego przekroczenia bariery, którą sobie widomie wytyczył. Jednakże na temat stosunku Polaków chrześcijan do Żydów nie ma wiele dobrego do powiedzenia - nie ma i Steinlauf, i w ogóle nie ma. Że zatem do symetrii w dalszym ciągu bardzo tutaj daleko, pojawia się w tej historii trauma: Deus czy Judeus - ex machina. Jest to coś na kształt wspomnianego już środka magicznego (волшебное средство), który w bajce magicznej (волшебная сказка) ројаwia się w sytuacjach bez wyjścia, by narracja mogła toczyć się dalej.

Z wywodu Steinlaufa jasno wynika, że grupa większościowa w majestacie kultury dominującej dopuszczała się wielowiekowej przemocy wobec grupy mniejszościowej z apogeum w czasie Zagłady. Ale przynajmniej - dowodzi Steinlauf - doznała wskutek tego traumy. Prócz funkcji fatycznej - podtrzymującej komunikację niczym wtrącenia typu „Uhm” lub „Aha” - koncepcja traumy jest zatem także bardzo konkretnym okupem czy opłatą za dopuszczenie do rozmowy. (Opłatą wnoszoną w walucie kapitału symbolicznego, gdyż do kapitału symbolicznego zostaje sprowadzone w tej transakcji to, co dla Steinlaufa najintymniejsze, okupione najwyższą ceną zupełnie innego rodzaju.) Koncepcja traumy oznacza bowiem, że obok Żydów również Polska i Polacy byli ofiarami Zagłady.

„Niemożność przyjęcia do wiadomości, przyswojenia sobie, ogarnięcia, czyli bycia w pełni świadomym świadkiem wydarzeń Zagłady w pełnej ich grozie, nie była wyjątkową cechą Polaków. [...] Dotyczyło to również Żydów w gettach, którzy mieli nadzieję, że dopóki będą użyteczni dla Niemców, mają zapewnione przetrwanie, a później wchodząc do komór gazowych, wierzyli, że idą pod prysznic. [...] Skoro nikt w czasach Zagłady nie był w stanie dostrzec w pełni tego, co się wówczas stało, zarówno ofiary, które przetrwały wojnę, jak i sprawcy oraz postronni obserwatorzy musieli przez wszystkie późniejsze lata borykać się z konsekwencjami tej niemożności. Dopiero niedawno zaczęliśmy rozumieć, że to wydarzenie bez świadków prześladuje nas wszystkich [...]" (Steinlauf, 2001, ss. 68-69) ${ }^{103}$.

Przy takiej konceptualizacji faktyczne postawy i zachowania obserwatorów uczestniczących nie dają się ani nazwać, ani opisać. O Żydach również bezpieczniej sądzić - kosztem faktów - że w masie swojej nie uciekali i nie walczyli, ponieważ nie orientowali się

103 Do grupy straumatyzowanych Zagładą Steinlauf zalicza także „większość sprawców, niemieckich biurokratów, którzy nie chcieli wiedzieć i byli systematycznie chronieni przed prawdą" (Steinlauf, 2001, s. 68). Steinlauf dzieli się traumą Zagłady z mordercami zza biurka. Jednakże wyrażone przez niego przekonanie jest charakterystyczne dla szerszego nurtu myślenia. W powojennych Niemczech popularna była bowiem również teza o nieświadomości sprawców Zagłady działających w terenie. Swego czasu pogląd ten wyprowadził z równowagi sąd w Bielefeld, który - analizując stan wiedzy i świadomości więźniów getta białostockiego w początkach roku 1943 (również na podstawie dokumentów z epoki) - przeprowadził dowód odwrotny: „Odnośnie do deportacji z lutego 1943 z Białegostoku 12 z 17 żydowskich świadków zeznało przed sądem, że na początku lutego wiedzieli, przypuszczali lub przynajmniej bali się, że deportacje oznaczają śmierć. Dziewięciu świadków zeznało, że wiedziało o funkcji Treblinki w tym czasie. Na podstawie tych informacji sąd wysnuł wniosek, że oskarżeni mieli świadomość celu transportów, stwierdzając, iż «byłoby groteskowe zakładać, że ofiary, które były uwięzione, obserwowane i szpiegowane, wiedziały więcej niż poplecznicy prześladowców. Tak nie było...» [Wyrok 5 Ks 1/65, Landesarchiv Nordrhein-Westfalen, Abteilung Ostwestfalen-Lippe, D 21 A, 6195, p. 200]" (Stoll, 2010, ss. 183-184 - tłumaczenie fragmentu Marcin Siadkowski). Stoll przekonująco wykazuje w swoich pracach, że stawką tezy o nieświadomości niemieckich sprawców Zagłady jest wizerunek społeczeństwa niemieckiego jako całości. 
w sytuacji104. Można nie myśleć o ich zatrzaśnięciu w śmiertelnej pułapce, jaką tworzył „mur wokół muru”. Niezrozumiała staje się wówczas rozpaczliwa i zażarta, nieprzebierająca w środkach walka o uniknięcie wywózki. Można też pominąć tragiczny los licznych uciekinierów i nielicznych walczących zbrojnie, który znowu odsyła do postaw i zachowań grupy większościowej.

Opisując przemiany ustrojowe w Polsce, Steinlauf stara się dać szansę optymizmowi i nadziei na gruntowną przemianę polskiej opowieści. Stąd być może smutek, jaki pozostawia po sobie lektura książki - tym większy, im weselsze jest tak zwane odrodzenie kultury żydowskiej w Polsce, którego początki autor miał możność oglądać na własne oczy w latach osiemdziesiątych XX wieku. Steinlauf dzieli się traumą Zagłady z Polakami. Jego książka pochodzi z okresu, kiedy koncepcja odrębnego Holokaustu na Polakach za to tylko, że byli Polakami - z rąk radzieckich - i wcześniejszego niż Holokaust na Żydach nie była jeszcze tak rozpowszechniona jak obecnie ${ }^{105}$. Ostatecznie jednak - wraz ze zrównaniem dwóch totalitaryzmów - koncepcja ta przeważyła. Dar został wzgardzony.

„Jak mnie polubi, to może kiedyś mnie nie zastrzeli” - perswadował sobie Władek Spiegelman w Mausie (Spiegelman, 2010, s. 220). Toutes proportions gardées: trauma to Łyżka miodu w beczce dziegciu, dzięki czemu Polacy może kiedyś nie trzasną drzwiami. Tym sposobem mamy dialog, który nie jest wprawdzie żadnym dialogiem, ale za to nie zostaje zerwany. Fundamentalną jego wadę, czyli fikcyjność, jakoby równoważą pozorne zalety: stabilność i przewidywalność. Dzięki temu możemy znowu być razem, a nawet - co dawniej nie bywało - wspólnie tańczyć na żydowskim pogrzebie. Na przykład na krakowskim Kazimierzu, na Placu Wolnica, pod płaskorzeźbą wyobrażającą przyjęcie Żydów do Polski w średniowieczu, gdzie Polaków symbolizuje skrzydlaty anioł w koronie króla Kazimierza Wielkiego.

\section{Postulaty badawcze}

Koncepcja polskiego doświadczenia Zagłady jako traumy w moim przekonaniu stanowi blokadę uniemożliwiającą rozpoznanie przedmiotu badania (polskiego doświadczenia Zagłady). Została bowiem ufundowana na nieporozumieniu. Owo fundacyjne

104 „Lekarz, dr Aron Bejlin, wspominat o tym, co działo się w lutym czterdziestego trzeciego w pociągu z Białegostoku - przez Małkinię - do Auschwitz. [Uwięzieni Żydzi byli przekonani, że jadą do pobliskiego obozu zagłady w Treblince. Wybór oddalonego Auschwitz stanowił dodatkową torturę. - E.J.] Mówił o «strasznych scenach». Opisywał tłok, strach przed śmiercią, próby samobójcze kobiet, próby ucieczek mężczyzn, śmierć poszczególnych deportowanych, brak jedzenia i picia, beznadziejne wołanie o pomoc, brutalność i upokorzenia ze strony strażników na rampach, brak współczucia i solidarności ze strony obserwujących całe wydarzenie i świadomość braku wyjścia z sytuacji [por. Przesłuchanie świadka dr. Arona Bejlina przez sąd przysięgłych w Bielefeld w procesie przeciwko dr. Altenlohowi i innym (sygn. 5 Ks 1/65), 25 V 1966 r., taśma magnetofonowa nr 18, strona druga, Landesarchiv Nordrhein-Westfalen, Abteilung Ostwestfalen-Lippe, D 21 A, nr 6341]" (Stoll, 2012, s. 563 - tłumaczenie fragmentu Marcin Siadkowski).

105 Steinlauf cytuje jedynie prace Richarda C. Lukasa (Lukas, 1989, 1995). Lukas konsekwentnie zamazuje różnice między hitlerowską polityką wobec Żydów i wobec Polaków oraz „przywłaszcza termin Holocaust bez żadnych modyfikacji, by określić polskie doświadczenia lat wojny” (por. Steinlauf, 2001, s. 56, przypis 18). Na mocy imperatywu symetrii prace Lukasa zestawia Steinlauf z opracowaniem Shmuela Krakowskiego Holocaust in the Polish Underground Press (Krakowski, 1984), które - mimo skrupulatności merytorycznej - jakoby "grzeszy prowokacyjnym tonem" (Steinlauf, 2001, s. 56, przypis 18). 
i fundamentalne nieporozumienie polega na arbitralnym, życzeniowym uznaniu za powrót wypartego czegoś, co jest reprodukcją prostą wzoru większościowej kultury dominującej. Mówienie o hipotetycznej traumie rzekomego świadka nie pozwala dostrzec trwałości mechanizmów przemocy i wykluczenia, których ciągłość nie została zerwana ${ }^{106}$. Inercyjne powtarzanie wzoru kultury trudno nazwać traumą - w szczególności tam, gdzie wyjściowo kategoria traumy odnosi się do grupy ofiar, których egzystencja została naznaczona przez tę właśnie kulturę doświadczeniem niemieszczącym się w języku tej kultury.

Umieszczenie ofiar przemocy i współsprawców oraz sprawców przemocy w jednej kategorii skutkuje wiktymizacją współsprawców i sprawców (Sznaider, 2011). Wiktymizacja zaś skutkuje dekontekstualizacją, czyli pominięciem historycznego konkretu. Beneficjentem traumatycznego qui pro quo jest współsprawca i sprawca przemocy, ofiarą zaś - ofiara. Z pola widzenia znikają społeczno-kulturowe uwarunkowania przemocy. Tymczasem to właśnie one sprawiają, że milczenie faktycznych ofiar i faktycznych współsprawców oraz sprawców przemocy nie jest ani tożsame, ani równoważne. Milczenie jednych i drugich jest produkowane przez system opresji z całkowicie różnych pozycji. System ów obsługuje bowiem interesy opresora ${ }^{107}$, a zwrócony jest przeciwko ofierze. (Cały czas należy przy tym pamiętać, że założenie, iż ofiary milczą, nie oddaje niezliczonych sytuacji, w których głos ofiar jest uciszany, podlega wrogiemu przejęciu lub rozlega się w próżni społeczno-kulturowej.)

Fałszywa uniwersalizacja eliminuje kontekst społeczno-kulturowy, przez co pozwala nie widzieć różnicy między warunkami i stawkami milczenia ofiar a warunkami i stawkami milczenia współsprawców oraz sprawców przemocy. Teoria traumy przestaje być wówczas teorią, a zaczyna nabierać cech systemu wierzeń, w którego centrum znajduje się bliżej nieokreślona (prze)moc. Konstrukt niepoznanej i niepoznawalnej przemocy jest zaś użytecznym narzędziem polityk historycznych stawiających sobie za cel zachowanie status quo opartego na dyskryminacji i wykluczeniu. Topos bliżej nieokreślonej przemocy stanowił dominantę przemówienia, jakie w obozie zagłady Żydów Auschwitz II Birkenau wygłosił Benedykt XVI. Szef instytucji gruntownie skompromitowanej za sprawą Zagłady (i nadal reglamentującej dostęp do swoich archiwów z tego okresu) wypowiedział mianowicie pytanie: „Gdzie był Bóg?” w sytuacji, gdy na wyjaśnienie oczekuje szereg kwestii związanych z tym, gdzie był wówczas Kościół katolicki. Dyskursywna operacja przeprowadzona przez rzymskiego papieża polegała na przekierowaniu uwagi z konkretnej przemocy na nadprzyrodzoną moc: Boga i - w domyśle -

106 Dziękuję Katrin Stoll, która zwróciła mi uwagę na refleksję Slavoja Žižka: „Claude Lanzmann’s Shoah alludes to the trauma of the Holocaust as something beyond representation (it can be discerned only via its traces, surviving witnesses, remaining monuments); however the reason for this impossibility of representing the Holocaust is not simply that it is «too traumatic» but rather, that we, observing subjects, are still involved in it, are still a part of the process which generated it” (Žižek, 2008, s. 276). Uważam, że brak rewizji kultury po Zagładzie w Europie Wschodniej oznacza reprodukcję i legitymizacje „of the very logic that brought the Holocaust about" (Žižek, 2008, s. 276): „Jakbyśmy symbolicznie odnawiali logikę i powtarzali gest zbrodni. Jakbyśmy stale dowodzili - komu? samym sobie? - że masakra nie mogła odbyć się bez nas” (Janicka, 2006, s. 103).

107 Słowo „opresor” nie występuje w korpusie języka polskiego. Świadomie zatem decyduję się na kalkę z łaciny. Za dyskusję na ten temat składam podziękowanie Dorocie Leśniewskiej. 
Szatana. „W takiej sytuacji można się już tylko skupić na efektach działania tej siły i spustoszeniach, jakie poczyniła w tożsamości swoich ofiar" (Snochowska-Gonzalez, 2013, s. 266) $)^{108}$ - w najszerszym tego słowa rozumieniu. Oznacza to cofnięcie refleksji nad Zagładą do poziomu kategoryzacji sprzed triady Hilberga, która wszak wymaga przezwyciężenia na rzecz narzędzia bardziej, a nie mniej precyzyjnego.

Krytyka koncepcji polskiego doświadczenia Zagłady jako traumy wymaga dalszych analiz w świetle ujęć, które przyczyn pomijania Zagłady w opowieści współsprawców i sprawców upatrują poza psychologią (Por. Arel, 2010; Noiriel, 2007) ${ }^{109}$. Chodzi o to, czy w świetle konstytucji zbiorowego podmiotu, jakim była grupa zewnętrzna wobec ofiar, Zagłada miała w ogóle potencjał urazowy. W naukach społecznych istnieje wszak myślenie o zbiorowej przemocy większości wobec mniejszości jako zachowaniu konformistycznym i niedewiacyjnym - jako „moralizatorskiej reakcji na zachowania odbiegające od normy” oraz „ekstremalnej formie samopomocy o charakterze kontroli społecznej, usiłującej rozwiązać sytuację sporną na drodze jednostronnej agresji" (Senechal de la Roche, 1996, ss. 97-98; por. Senechal de la Roche, 2001). Koncepcję pamięci nieprzyswojonej należy również przeanalizować w zestawieniu z teorią zmowy milczenia Eviatara Zerubavela oraz koncepcją cugli kulturowych Jeffreya Olicka, który to kontekst badawczy zapożyczam od Joanny Tokarskiej-Bakir (Tokarska-Bakir, 2012a, s. 238). Na wyjaśnienie zasługuje następnie, w jakim trybie przebiegał w Polsce wysiłek pomijania, jak wyglądała jego ewolucja w czasie, na ile był on odgórny, na ile oddolny - w sensie umiejscowienia na drabinie społecznej jego autorów ${ }^{110}$.

Perspektywa analityczna wymaga zaliczenia do grona producentów sensu - obok władz PRL - również Kościoła rzymskokatolickiego oraz inteligencji, dotychczas pomijanych w badaniach z uwagi na ograniczenia percepcyjne grupy większościowej i jej elit. Kościół i inteligencja to więcej niż użytkownicy dyskursu, to jego prawodawcy. Zwłaszcza Kościół rzymskokatolicki był potężnym, instytucjonalnym aktorem sceny pamięci i tożsamości, alternatywnym wobec władz PRL. Hierarchia partyjno-państwowa liczyła się z Kościołem jako przeciwnikiem w walce o prawomocność i uczestnikiem rywalizacji

108 Snochowska-Gonzalez analizuje proces rozmycia i unieszkodliwienia narzędzi badawczych na przykładzie wszechogarniających zastosowań teorii postkolonialnej.

109 Również Raul Hilberg w drugim wydaniu Zagłady Żydów europejskich (1985) odszedł od opisywania kondycji sprawców w kategoriach mechanizmów psychologicznych (,poczucia winy”, ,skrupułów moralnych”, ,krytycznego oka własnego sumienia”, „wyparcia” czy „racjonalizacji”) na rzecz postrzegania ich jako podmiotów wyposażonych w moralną legitymację i stanowiących rzeczywistość pozytywną w kategoriach i w obrębie ich własnego układu społeczno-kulturowego odniesienia (por. Browning, 2013, ss. 669-670). W podobny sposób nieproblematyczną psychologicznie postacią był Franz Stangl, uczestnik akcji T4, komendant Sobiboru i Treblinki, dodatkowo upewniony w słuszności swej drogi przez zaufanego spowiednika (por. Sereny, 2002). Jeden z morderców Żydów z Jedwabnego „napisze później w podaniu o łaskę, że właściwie nie rozumie, o co chodzi [...]; przecież wychowano go przed wojną w duchu narodowym, a podczas wojny w okolicy wszędzie mordowano Żydów!" (Gross, 2003a, s. 75). „10 lipca 1941 r. Zygmunt i Jerzy Laudańscy bili i mordowali Żydów w Jedwabnem wraz z rozjuszonym tłumem swoich sąsiadów. Zamordowano tego dnia całą społeczność jedwabieńskich Żydów, włączając w to dzieci, kobiety i starców. W konkluzji wywiadu opublikowanego z braćmi Laudańskimi w «Gazecie Wyborczej» (10-11 marca 2001) Zygmunt Laudański powiedział, że niczego w życiu nie żałuje. Kazimierz Laudański, którego wówczas w Jedwabnem akurat nie było, przedstawiał po latach biografię swego młodszego brata, Jerzego, jako wzór postawy patriotycznej - «dla mnie, i nie tylko dla mnie, pozostanie bohaterem» («Rzeczpospolita», 2 lutego 2001)" (Gross, 2003b, s. 96).

110 Pytanie to podejmują cytowane prace Sylwii Karolak i Grzegorza Niziołka. 
W nacjonalizmie ${ }^{111}$. W oczach większości natomiast Kościół nie tylko używał dyskursu prawomocnego, lecz także rozstrzygał o kryteriach prawomocności i był jej szafarzem, legitymizując/delegitymizując dyskursy.

Następnie należy zapytać, czy pojawiały się głosy alternatywne wobec narracji dominujących. A jeżeli tak, to kiedy i jakie, i dlaczego nie udało im się uformować w rozpoznawalny kanon. Na odpowiedź czeka wreszcie pytanie, gdzie podziała się rozproszona reszta bez imienia i bez przyporządkowania, czyli współczucie (heteropatia). Czy odcisnęła ślad swego istnienia w narracjach dominujących i czy miała jakiekolwiek konsekwencje w postaci zaburzenia czy zmiany ich toku? Odpowiedzi na te pytania nie sposób poszukiwać $\mathrm{w}$ ramach zakreślonych przez koncepcję polskiego doświadczenia Zagłady jako traumy i za pomocą właściwej jej aparatury pojęciowej. Stąd konieczność dalszej rewizji, a w konsekwencji odrzucenia podstawowych dotychczas kategorii opisu takich, jak świadek, obojętność, bezsilność, bierność, pomoc, dziedzictwo czy stosunki polsko-żydowskie, a także natura ludzka i/lub tajemnica duszy ludzkiej, gdyż i na takie konstrukty można napotkać w historiografii Zagłady.

Koncepcja polskiego doświadczenia Zagłady jako traumy najczęściej - i zapewne nieintencjonalnie - skutkuje otoczeniem ochroną tego, co nazywane bywa polskością, a na co składają się chrześcijaństwo (zwłaszcza katolicyzm) i antykomunizm (w sensie opisanego powyżej antykomunistycznego paradygmatu). Niezależnie od tego, czy nazwiemy to paradygmatem nacjonalistycznym, czy patriotycznym - jak wolą elity wszystkich politycznych orientacji - dopóki nie skierujemy uwagi na sam rdzeń polskiej kultury dominującej, dopóty nie będziemy w stanie zrozumieć historii antysemityzmu w Polsce przed Zagładą, w trakcie Zagłady i po Zagładzie, z jego dzisiejszą kondycją włącznie.

„Teza, że źródłem dość powszechnej w powojennej Polsce niechęci wobec Żydów była trauma wywołana świadkowaniem Zagładzie oraz wynikające z niej poczucie winy niejako zwalnia Polaków od odpowiedzialności. Co prawda - zdaje się mówić autor [Steinlauf - E.J.] w powojennej Polsce spotykamy się ze zjawiskiem antysemityzmu, ale należy to tłumaczyć ciężkimi doświadczeniami wojennymi oraz doznanym w ich skutku urazem psychicznym" (Wóycicka, 2002, s. 178).

„Od tej chwili historia staje się historią negatywną - [...] wirtualną sceną czynów niepojętych. Michael R. Marrus nazywa historię Holokaustu historią braku działania, obojętności, niewrażliwości (inaction, indifference, insensivity)" (Marrus, 1987, s. 157 - cyt. za: Niziołek, 2013, s. 50).

Cały ten zespół rozpoznań w polskim kontekście jest fałszywy. Na gruncie polskim a i wschodnioeuropejskim - postulat wzięcia odpowiedzialności za własną historię i kulturę przez grupę większościową jest postulatem rewolucyjnym. Zakłada osiągnięcie samoświadomości i samoupodmiotowienie ze strony dziedziców tej historii i nosicieli tej kultury, którzy nie nawykli do postrzegania siebie jako działających podmiotów. Warunkiem na pewno niewystarczającym, ale też z całą pewnością koniecznym na drodze

111 Por. studium przypadku wyłaniające mechanizmy i stawki owego współzawodnictwa: Żukowski, 2008. 
do samoupodmiotowienia jest odrzucenie koncepcji polskiej większości jako bystanders czy onlookers - gapia, postronnego obserwatora czy świadka (na rzecz obserwatora uczestniczącego) - oraz koncepcji polskiego doświadczenia Zagłady jako zbiorowej traumy.

1 marca 2014

\section{Bibliografia}

Andrzejewski, J. (1947). Zagadnienie polskiego antysemityzmu. W J. Andrzejewski i in., Martwa fala. Zbiór artykutów o antysemityzmie (ss. 20-50). Warszawa: Spółdzielnia Wydawnicza „Wiedza”.

Arad, Y. (2012). La réécriture de la Shoah en Lituanie d'après les sources lituaniennes. Revue d'Histoire de la Shoah, (197), 607-660.

Arel, D. (2010). L'Ukraine, la guerre et le principe de responsabilité collective. W G. Mink \& P. Bonnard (Red.), Le Passé au présent. Gisements mémoriels et actions historicisantes en Europe centrale et orientale (ss. 83-102). Paris: Michel Houdiard Éditeur.

Auerbach, R. (2012). Treblinka. Reportaż. Zagłada Żydów, (8), 25-75.

Auschwitz-Birkenau. (b.d.). Pobrano 2 lutego 2014, z http://pl.auschwitz.org/m/index.php?option=com_ponygallery\&func $=$ detail \&id=1254\&ltemid $=17$

Bacon, F. (1955). Novum Organum. (J. Wikarjak, Tłum.). Warszawa: Państwowe Wydawnictwo Naukowe.

Baksik, Ł. (2013). Macewy niecodziennego użytku. W J. Tokarska-Bakir (Red.), PL: tożsamość wyobrażona (ss. 99-126). Warszawa: Czarna Owca.

Barthes, R. (2009). Stopień zero pisania oraz Nowe eseje krytyczne. (K. Kot, Tłum.). Warszawa: Aletheia.

Bauman, Z. (1994). Dwa szkice o moralności ponowoczesnej. Warszawa: Instytut Kultury Wydziału Polonistyki UW.

Berendt, G. (2008). Cena życia - ekonomiczne uwarunkowania egzystencji Żydów po „aryjskiej stronie”. Zagłada Żydów, (4), 110-143.

Bieńkowski, Z. (1989, październik 8). Mesjasz nie przyszedt. Tygodnik Kulturalny, ss. I-II.

Bilewicz, M., \& Haska, A. (2012, październik 1). Wiara w mord rytualny we współczesnej Polsce. Pobrano 1 października 2013, z http://www.otwarta.org/index.php/kto-wierzy-w-mord-rytualny

Błoński, J. (1994). Biedni Polacy patrzą na getto. Kraków: Wydawnictwo Literackie.

Borwicz, M. (1980). Kazimierza Moczarskiego „Rozmowy z katem”. Zeszyty Historyczne (Paryż), (53), 177-185.

Bourdieu, P. (2004). Męska dominacja. (L. Kopciewicz, Tłum.). Warszawa: Oficyna Naukowa.

Bourdieu, P. (2006a). Medytacje pascaliańskie. (K. Wakar, Tłum.). Warszawa: Oficyna Naukowa.

Bourdieu, P. (2006b). Uniwersalność strategii uniwersalizacji. W P. Bourdieu, Medytacje pascaliańskie (ss. 173-181). (K. Wakar, Tłum.). Warszawa: Oficyna Naukowa.

Brama, M., \& Grabowski, Z. (2007, czerwiec 6). Archiwum Historii Mówionej - Zbigniew Grabowski. Pobrano 12 czerwca 2015, z http://ahm.1944.pl/Zbigniew_Grabowski

Bratkowski, P., \& Keff, B. (2013, październik 21). Kronika zapowiedzianej śmierci. Z Bożeną Keff rozmawia Piotr Bratkowski. Newsweek, ss. 112-114.

Browning, C. R. (2013). Raul Hilberg. Zagłada Żydów, (9), 661-672.

Bryk, A. (1990). The hidden complex of the Polish mind: Polish-Jewish relations during the Holocaust. W A. Polonsky (Red.), My brother's keeper: Recent Polish debates on the Holocaust (ss. 161-184). London, New York: Routledge in association with Institute for Polish-Jewish Studies.

SLH 3/4 2014/2015 | str. 218 
Calderón Puerta, A. (2010). Ciało (nie)widzialne: spektakl wykluczenia w „Przy torze kolejowym” Zofii Nałkowskiej. Teksty Drugie, (6), 137-153.

Cała, A. (2005). Wizerunek Żyda w polskiej kulturze ludowej. Warszawa: Oficyna Naukowa.

Caruth, C. (2010). Doświadczenie niczyje: trauma i możliwość historii (Freud, Mojżesz i monoteizm). (K. Bojarska, Tłum.). Teksty Drugie, (6), 111-123.

Chmielarz, A. (2009). Kategorie represji stosowanych przez okupanta niemieckiego wobec obywateli polskich. W W. Materski \& T. Szarota (Red.), Polska 1939-1945. Straty osobowe i ofiary represji pod dwiema okupacjami (ss. 91-100). Warszawa: IPN - Komisja Ścigania Zbrodni przeciwko Narodowi Polskiemu.

Dawidowicz, L. (1981). Appropriating the Holocaust: Polish historical revisionism. W L. Dawidowicz, The Holocaust and the historians (ss. 88-124). Cambridge, Mass.: Harvard University Press.

Dawidowicz, L. (2008). From that place and time. A memoir, 1938-1947. (N. Sinkoff, Wstęp). New Brunswick, NJ: Rutgers University Press.

Dobroszycki, L. (1993). Polish historiography on the annihilation of the Jews of Poland in World War II: A critical evaluation. East European Jewish Affairs, 23(2), 39-49. http://doi.org/10.1080/13501679308577750

Donskis, L. (2013, styczeń 19). Litwini, nie kompromitujmy się. Gazeta Wyborcza, ss. 36-37.

Dunin, K. (2004). Polacy ludziom. W K. Dunin, Czytając Polskę (ss. 72-78). Warszawa: W.A.B.

Eisenbach, A. (1961). Hitlerowska polityka zagłady Żydów. Warszawa: Książka i Wiedza.

Engel, D. (1987). In the shadow of Auschwitz: The Polish government-in-exile and the Jews, 1939-1942. Chapel Hill: University of North Carolina Press.

Engel, D. (1993). Facing a Holocaust: The Polish government-in-exile and the Jews, 1943-1945. Chapel Hill: University of North Carolina Press.

Engelking, B. (2011). Jest taki piękny stoneczny dzień. Losy Żydów szukających ratunku na wsi polskiej 1942-1945. Warszawa: Stowarzyszenie Centrum Badań nad Zagładą Żydów.

Engelking, B., \& Gutman, I. (2013). Z profesorem Izraelem Gutmanem rozmawia Barbara Engelking. Zagłada Żydów, (9), 207-242.

Engelking, B., \& Libionka, D. (2009). Żydzi w powstańczej Warszawie. Warszawa: Stowarzyszenie Centrum Badań nad Zagładą Żydów.

Fein, H. (1979). Accounting for Genocide: National responses and Jewish victimization during the Holocaust. Chicago: University of Chicago Press.

Forecki, P. (2010a). Spory o symboliczne panowanie nad Auschwitz-Birkenau. W P. Forecki, Od "Shoah" do "Strachu”. Spory o polsko-żydowska przeszłość i pamięć w debatach publicznych (ss. 167-280). Poznań: Wydawnictwo Poznańskie.

Forecki, P. (2010b). Zbiorowe zapominanie Zagłady w PRL. W P. Forecki, Od "Shoah" do "Strachu”. Spory o polsko-żydowską przeszłość i pamięć w debatach publicznych (ss. 13-114). Poznań: Wydawnictwo Poznańskie.

Foucault, M. (2009). Nadzorować i karać. Narodziny więzienia. (T. Komendant, Tłum.). Warszawa: Aletheia.

Friedländer, S. (1993). Memory, history and the extermination of the Jews of Europe. Bloomington, Indianapolis: Indiana University Press.

Friedman, F. (1946). Zagłada Żydów polskich. Biuletyn Głównej Komisji Badania Zbrodni Niemieckich w Polsce, 1, 147165.

Fulbrook, M. (2012). A Small Town near Auschwitz. Ordinary Nazis and the Holocaust. Oxford: Oxford University Press

Gilman, S. L. (1990a). Introduction: What are stereotypes and why use texts to study them? W S. L. Gilman, Difference and pathology: Stereotypes of sexuality, race and madness (ss. 15-35). Ithaca, London: Cornell University Press.

Gilman, S. L. (1990b). Jewish self-hatred. Anti-semitism and the hidden language of the Jews. Baltimore, London: The Johns Hopkins University Press. 
Glazar, R. (2011). Stacja Treblinka. (E. Czerwiakowska, Posłowie \& Tłum.). Warszawa: Ośrodek KARTA \& Dom Spotkań z Historią.

Głowiński, M. (1999). Kwadrans w cukierni. W M. Głowiński, Czarne sezony (ss. 91-96). Warszawa: Open.

Goffman, E. (2007). Piętno. Rozważania o zranionej tożsamości. (J. Tokarska-Bakir, Wstęp, A. Dzierżyńska \& J. Tokarska-Bakir, Tłum.). Gdańsk: Gdańskie Wydawnictwo Psychologiczne.

Grabowski, J. (2008). Ratowanie Żydów za pieniądze - przemysł pomocy. Zagłada Żydów, (4), 81-110.

Grabowski, J. (2011). Judenjagd. Polowanie na Żydów 1942-1945. Studium dziejów pewnego powiatu. Warszawa: Stowarzyszenie Centrum Badań nad Zagładą Żydów.

Grabowski, J. (2014a, marzec 31). Upamiętnianie Polaków niosących pomoc. Pobrano z http://www.holocaustresearch. pl/index.php?mod=news \&show $=285$

Grabowski, J. (2014b, kwiecień 26). W sprawie Zagłady Polska gola! Gazeta Wyborcza, ss. 30-31.

Grabowski, J., \& Libionka, D. (Red.). (2014). Klucze i kasa. O mieniu żydowskim w Polsce pod okupacją niemiecka i we wczesnych latach powojennych 1939-1950. Warszawa: Stowarzyszenie Centrum Badań nad Zagładą Żydów.

Gross, J. T. (1986). Ten jest z ojczyzny mojej... ale go nie lubię. Aneks, (41-42).

Gross, J. T. (1993). The Jewish community in the Soviet-annexed territories on the eve of the Holocaust. A social scientist's view. W L. Dobroszycki \& J. S. Gurock (Red.), The Holocaust in the Soviet Union. Studies and sources on the destruction of the Jews in the Nazi-occupied territories of the USSR, 1941-1945 (ss. 155-171). New York, London: M.E. Sharpe.

Gross, J. T. (1998). „Ten jest z Ojczyzny mojej...”, ale go nie lubię. W J. T. Gross, Upiorna dekada. Trzy eseje o stereotypach na temat Żydów, Polaków, Niemców i komunistów 1939-1948 (ss. 25-60). Kraków: Towarzystwo Autorów i Wydawców Prac Naukowych „Universitas”.

Gross, J. T. (2000). Sąsiedzi. Historia zagłady żydowskiego miasteczka. Sejny: Pogranicze.

Gross, J. T. (2003a). A jednak sąsiedzi. W J. T. Gross, Wokót „Sąsiadów”. Polemiki i wyjaśnienia (ss. 69-87). Sejny: Pogranicze.

Gross, J. T. (2003b). Autor „Sąsiadów” przyznaje się do pomyłki. W J. T. Gross, Wokót „Sąsiadów”. Polemiki i wyjaśnienia (ss. 95-96). Sejny: Pogranicze.

Gross, J. T. (2003c). Posłowie. W J. T. Gross, Wokót „Sąsiadów”. Polemiki i wyjaśnienia (ss. 117-119). Sejny: Pogranicze.

Gross, J. T. (2007). Upiorna dekada. Eseje o stereotypach na temat Żydów, Polaków, Niemców, komunistów i kolaboracji 1939-1948. Kraków: Austeria.

Gross, J. T. (2012). Macewy wrócą na cmentarz. W Ł. Baksik, Macewy codziennego użytku [Matzevot for everyday use] (ss. 15-16). Wołowiec: Czarne.

Gross, J. T. (2014). Sprawcy, ofiary i inni. Zagłada Żydów, (10/t. 2), 885-888.

Gross, J. T., \& Grudzińska-Gross, I. (2011). Złote żniwa. Rzecz o tym, co się działo na obrzeżach zagłady Żydów. (J. Grabowski, Przedmowa). Kraków: Znak.

Grynberg, H. (1984a). Ludzie Żydom zgotowali ten los. W H. Grynberg, Prawda nieartystyczna (ss. 65-88). West Berlin: Archipelag.

Grynberg, H. (1984b). Obsesyjny temat. W H. Grynberg, Prawda nieartystyczna (ss. 131-144). West Berlin: Archipelag.

Hering, L. (2011). Meta. W L. Hering, Ślady. Opowiadania (ss. 31-101). Warszawa: Czarna Owca. (Pierwodruki fragmentów tekstu: „Kuźnica” 1945, nr 10, s. 2 i „Głos Ludu” 1945, nr 279, s. 2).

Heuner, J. (2003). Auschwitz, Poland, and the politics of commemoration, 1945-1979. Athens: Ohio University Press.

Hilberg, R. (2007). Sprawcy, ofiary, świadkowie. Zagłada Żydów 1933-1945. (J. Giebułtowski, Tłum.). Warszawa: Stowarzyszenie Centrum Badań nad Zagładą Żydów \& Cyklady.

Janicka, E. (2001, lipiec 19). Żyda portret zbiorowy. Gazeta Wyborcza, s. 14.

Janicka, E. (2006). Hortus Judeorum. W R. Dziadkiewicz \& E. M. Tatar (Red.), Imhibitio (ss. 99-109). Kraków: Muzeum Narodowe w Krakowie \& Korporacja Ha!art.

SLH 3/4 2014/2015 | str. 220 
Janicka, E. (2008). Mord rytualny z aryjskiego paragrafu. O książce Jana Tomasza Grossa „Strach”. Antysemityzm w Polsce tuż po wojnie. Historia moralnej zapaści. Kultura i Społeczeństwo, 52(2), 229-252.

Janicka, E. (2010). Holocaustization: The myth of the Warsaw Uprising in “Kinderszenen” by Jarosław Marek Rymkiewicz. W A. Molisak \& S. Ronen (Red.), Polish and Hebrew literature and national identity (ss. 275-289). Warsaw: Dom Wydawniczy Elipsa.

Janicka, E. (2011). Festung Warschau. (B. Keff, Wstęp). Warszawa: Wydawnictwo Krytyki Politycznej.

Janicka, E. (2012). O nowe kategorie opisu. W odpowiedzi Janowi Grabowskiemu. Zagłada Żydów, (8), 468 -474.

Janicka, E. (2013). Latający Cyrk im. Kazimierza Wielkiego przedstawia: „Najwęższy dom świata - wydarzenie na skalę globu". Rekonstrukcja historyczna w 70. rocznicę Akcji Reinhardt. Studia Litteraria et Historica, 2, 76-129. http://dx.doi. org/10.11649/slh.2013.005

Janicka, E. (2014). Zamiast negacjonizmu. Topografia symboliczna terenu dawnego getta warszawskiego a narracje o Zagładzie. Zagłada Żydów, (10/t. 1), 209-256.

Janicka, E., \& Żukowski, T. (2011, październik 29). Ci nie są z ojczyzny naszej. Gazeta Wyborcza, ss. 20-21.

Janion, M. (2000). Spór o antysemityzm. Sprzeczności, wątpliwości i pytania. W M. Janion, Do Europy - tak, ale razem z naszymi umarłymi (ss. 136-147). Warszawa: Sic!

Janion, M. (2009a). Aneks o Zagładzie. W M. Janion, Bohater, spisek, śmierć. Wykłady żydowskie (ss. 63-76). Warszawa: W.A.B.

Janion, M. (2009b). Mit założycielski polskiego antysemityzmu. W M. Janion, Bohater, spisek, śmierć. Wykłady żydowskie (ss. 77-145). Warszawa: Wydawnictwo W.A.B.

Janiszewski, J. (2008, 7 czerwca). Grabarka Rzeczypospolitej. Z Agnieszką Arnold rozmawia Jakub Janiszewski, Wysokie Obcasy, s. 20.

Jasiewicz, K. (2001). Pierwsi po diable. Elity sowieckie w okupowanej Polsce 1939-1941. Warszawa: Instytut Studiów Politycznych PAN \& Rytm.

Jasiewicz, K. (2013). Żydzi byli sami sobie winni? Rozmowa z prof. Krzysztofem Jasiewiczem. Focus Historia Ekstra, (2), $32-35$.

Jaspers, K. (1979). Problem winy. (J. Garewicz, Tłum.). Etyka, (17), 143-206.

Jedlicki, J. (2013, maj 4). Było, jak było. Podziemne harcerstwo i antysemityzm. Gazeta Wyborcza, s. 22.

Jurandot, J. (2014). Humor w opasce. W J. Jurandot, Miasto skazanych. 2 lata w warszawskim getcie (ss. 403-450). (P. Szapiro \& A. Arnold, Red.). Warszawa: Muzeum Historii Żydów Polskich.

Karolak, S. (2014). Doświadczenie Zagłady w literaturze polskiej 1947-1991. Kanon, który nie powstat. Poznań: Wydawnictwo Nauka i Innowacje.

Karski, J. (1999, październik 2-3). Widziałem. Opr. M. Cichy. Gazeta Wyborcza, s. 15.

Karski, J. (2014, listopad 15). Zagadnienie żydowskie w Polsce pod okupacjami. Gazeta Wyborcza, ss. 28-30.

Karwan-Makosch, P. (b.d.). Kępno. Pobrano 2 lutego 2014, z http://www.kirkuty.xip.pl/kepno.htm

Kersten, K. (1992). Problem Żydów w Polskich Siłach Zbrojnych w ZSRR i na Wschodzie w kontekście stosunków polsko-żydowskich w czasie II wojny światowej. W K. Kersten, Polacy, Żydzi, komunizm. Anatomia półprawd (1939-1968) (ss. 15-75). Warszawa: Niezależna Oficyna Wydawnicza.

Kersten, K. (1993). Rozważania wokół podziemia 1944-1947. W K. Kersten, Między wyzwoleniem a zniewoleniem. Polska 1944-1956 (ss. 28-99). Londyn: Aneks.

Kirchner, H. (2011). Ludzie ludziom. W H. Kirchner, Nałkowska albo życie pisane (ss. 569-596). Warszawa: W.A.B.

Kornbluth, A. (2013). „Jest wielu Kainów pośród nas”. Polski wymiar sprawiedliwości a Zagłada, 1944-1956. (E. Felska, Tłum.). Zagłada Żydów, (9), 157-172.

Kowalska, A., \& Baksik, Ł. (2012). Na naszym wybrukowanym macewami podwórku. Wywiad z Łukaszem Baksikiem. W Ł. Baksik, Macewy codziennego użytku [Matzevot for everyday use] (ss. 17-22). Wołowiec: Czarne. 
Krakowski, S. (1984). Holocaust in the Polish underground press. Yad Vashem Studies, (16), 241-270.

Krupa, B. (2011). O nieobecności Zagłady, czyli czytanie „Rozmów z katem” Kazimierza Moczarskiego. Zagłada Żydów, (7), 279-302.

Krzemiński, I. (2014, luty 1-2). Nie wierzę w przemianę Giertycha. Gazeta Wyborcza, s. 23.

Krzywicki, L. (2009). Ekscesy antyżydowskie na polskich uczelniach w latach trzydziestych XX wieku. Warszawa: Towarzystwo Wydawnicze i Literackie na zlecenie Stowarzyszenia Społeczno-Kulturalnego „Warszawa w Europie”.

Kurz, I., \& Wilczyk, W. (2011). Fotografia dokumentalna i archiwum. W K. Pijarski (Red.), The archive as project - the poetics and politics of the (photo)archive [Archiwum jako projekt - poetyka i polityka (foto)archiwum] (ss. 291-307). Warszawa: Archeologia Fotografii.

LaCapra, D. (2001). Writing history, writing trauma. Baltimore, London: The Johns Hopkins University Press.

Langer, L. L. (1991). Holocaust testimonies. The ruins of memory. New Haven: Yale University Press.

Laplanche, J., \& Pontialis, J.-B. (1996). Uraz psychiczny. W J. Laplanche, \& J.-B. Pontialis, Stownik psychoanalizy (ss. 340-344). (E. Modzelewska \& E. Wojciechowska, Tłum.). Warszawa: Wydawnictwa Szkolne i Pedagogiczne.

Legge, Jr., J. S. (2013). Opór wobec procesów w sprawie zbrodni wojennych: masakra w Malmédy, niemieckie Kościoły a kontrwywiad amerykański CIC. (E. Felska, Tłum.). Zagłada Żydów, (9), 173-203.

Les doutes de l'antifascisme. Table Ronde, 16 février 1990. (2010). W J.-C. Szurek, La Pologne, les Juifs et le communisme (ss. 30-51). Paris: Michel Houdiard Éditeur.

Libionka, D. (2006). ZWZ-AK i Delegatura Rządu RP wobec eksterminacji Żydów polskich. W A. Żbikowski (Red.), Polacy i Żydzi pod okupacją niemiecką 1939-1945. Studia i materiały (ss. 15-207). Warszawa: IPN - Komisja Ścigania Zbrodni przeciwko Narodowi Polskiemu.

Libionka, D. (2008a). Polskie piśmiennictwo na temat zorganizowanej i indywidualnej pomocy Żydom (1945-2008). Zagłada Żydów, (4), 17-80.

Libionka, D. (2008b). Zagłada domu Trinczerów - refleksje historyka. Znak, (4), 146-151.

Libionka, D. (2013). Uwagi o ratowaniu Żydów w „okolicach Treblinki”. Zagłada Żydów, (9), 687-695.

Libionka, D. (2014). Walka i propaganda. Powstanie w getcie warszawskim z perspektywy polskiego Londynu. Zagłada Żydów, (10/t. 1), 57-95.

Lipski, J. J. (1985). Dwie Ojczyzny i inne szkice. Warszawa: Myśl.

Lukas, R. C. (1989). Out of the Inferno. Poles remember the Holocaust. Lexington, Ky: University Press of Kentucky.

Lukas, R. C. (1995). Zapomniany Holokaust. Polacy pod okupacją niemiecką 1939-1944. Kielce: Jednorożec.

Łapa, M. (Red.). (2008). Żydzi kępińscy. Kępno: Wydawnictwo Tygodnika Kępińskiego „Pismak”.

Markiel, T. (2011). Gniewczyna w czas wojny. W T. Markiel, A. Skibińska (Red.), „Jakie to ma znaczenie, czy zrobili to z chciwości?”. Zagłada domu Trynczerów (ss. 21-133). Warszawa: Stowarzyszenie Centrum Badań nad Zagładą Żydów.

Marrus, M. R. (1987). The Holocaust in history, Hanover-London: University Press of New England.

Matyjaszek, K. (2013). Przestrzeń pożydowska. Studia Litteraria et Historica, 2, 130-147. http://dx.doi.org/10.11649/ slh.2013.006

Matyjaszek, K. (2014/2015). Regulamin rezerwatu. O książce „Jewish Poland Revisited” Eriki Lehrer. Studia Litteraria et Historica, 3/4, 79-108. http://dx.doi.org/10.11649/slh.2015.007.

Melchior, M. (2000). Michael C. Steinlauf, „Bondage to the Dead: Poland and the Memory of the Holocaust”, Syracuse University Press, Syracuse 1997. Przegląd Socjologiczny, (2), 232-235.

Melchior, M. (2004). Zagłada a tożsamość. Polscy Żydzi ocaleni na „aryjskich papierach”. Analiza doświadczenia biograficznego. Warszawa: Wydawnictwo IFiS PAN.

Melchior, M. (2013). Socjologiczne pojęcia i kategorie do opisu stosunków polsko-żydowskich w czasie okupacji. W Katedra Socjologii i Antropologii Obyczajów i Prawa ISNS UW (Red.), O społeczeństwie, prawie i obyczajach. Księga pamiątkowa ofiarowana profesorowi Jackowi Kurczewskiemu (ss. 386-396). Gdańsk: słowo/obraz terytoria. 
Michnik, A. (1977). Kościót, lewica, dialog, Paryż: Instytut Literacki.

Michnik, A. (2008, październik 25). Z dziejów honoru i zgnilizny (2). Gazeta Wyborcza, ss. 24-27.

Miłosz, C. (1999). Wyprawa w Dwudziestolecie. Kraków: Wydawnictwo Literackie.

Mink, G. (2010). Géopolitique, histoire et jeux de mémoire: pour une reconfiguration conceptuelle. W G. Mink \& P. Bonnard (Red.), Le Passé au présent. Gisements mémoriels et actions historicisantes en Europe centrale et orientale (ss. 7-38). Paris: Michel Houdiard Éditeur.

Młodzi mają coraz mniej uprzedzeń wobec Żydów. (2009, kwiecień 16). Pobrano 15 października 2013, z http://wiadomosci.gazeta.pl/wiadomosci/1,114873,6503745,Mlodzi_maja_coraz_mniej_uprzedzen_wobec_Zydow.html

Mulvey, L. (1975). Visual Pleasure and Narrative Cinema. Screen, 16(3), 6-18.

Nałkowska, Z. (1982). Przy torze kolejowym. W Z. Nałkowska, Medaliony (ss. 35-41). Warszawa: Krajowa Agencja Wydawnicza.

Natkowska, M. (1999). Numerus clausus, getto ławkowe, numerus nullus, „paragraf aryjski”. Antysemityzm na Uniwersytecie Warszawskim 1931-1939. Warszawa: ŻıH.

Nijakowski, L. M. (2013). O szczególnej figuracji sprawcy-ofiary-świadkowie. W L. M. Nijakowski, Rozkosz zemsty. Socjologia historyczna mobilizacji ludobójczej (ss. 83-86). Warszawa: Wydawnictwo Naukowe Scholar.

Niziołek, G. (2013). Polski teatr Zagłady. Warszawa: Instytut Teatralny im. Zbigniewa Raszewskiego \& Wydawnictwo Krytyki Politycznej.

Noiriel, G. (2007). À quoi sert „l'identité nationale”? Paris: Agone.

Od Redakcji. (2013). Zagłada Żydów, (9), 9-11.

Olszewski, M. (2014, grudzień 17). Historia pewnej klęski. Gazeta Wyborcza, s. 18.

Orwid, M. (2009). Trauma. Kraków: Wydawnictwo Literackie.

Ostolski, A. (2009). Przestrzeń muzeum i polityka traumy. Kultura i Społeczeństwo, 53(3), 67-87.

Paczkowski, A. (1991). Raporty o pogromie. Puls, 13(50), 101-121.

Pawłowski, R. (2001, kwiecień 21-22). Jude 2001. Gazeta Wyborcza, s. 13.

Perchoc, P. (2010). Les mutations du compromis mémoriel européen. Une étude balte. W G. Mink \& P. Bonnard (Red.), Le Passé au présent. Gisements mémoriels et actions historicisantes en Europe centrale et orientale (ss. 55-67). Paris: Michel Houdiard Éditeur.

Perechodnik, C. (2004). Spowiedź. Dzieje rodziny żydowskiej podczas okupacji hitlerowskiej w Polsce. (D. Engel, Opracowanie, Posłowie). Warszawa: Ośrodek KARTA.

Propp, V. I. (1969). Morfologiia skazki. Moskva: Nauka.

Propp, W. (1976). Morfologia bajki. (B. Gołębiowski, Wstęp, W. Wojtyga-Zagórska, Tłum.). Warszawa: Książka i Wiedza.

Przyboś, J. (1947). Hańba antysemityzmu. W J. Andrzejewski i in., Martwa fala. Zbiór artykułów o antysemityzmie (ss. 6064). Warszawa: Spółdzielnia Wydawnicza „Wiedza”.

Puławski, A. (2009). W obliczu Zagłady. Rząd RP na uchodźstwie, Delegatura Rządu RP na Kraj, ZWZ-AK wobec deportacji Żydów do obozów zagłady (1941-1942). Lublin: IPN.

Rudnicki, S. (1985). Obóz Narodowo-Radykalny. Geneza i działalność. Warszawa: Czytelnik.

Rusiniak, M. (2008). Obóz zagłady Treblinka II w pamięci społecznej (1943-1989). Warszawa: Neriton.

Rzepliński, A. (2002). Ten jest z ojczyzny mojej? Sprawy karne oskarżonych o wymordowanie Żydów w Jedwabnem W świetle zasady rzetelnego procesu. W P. Machcewicz \& K. Persak (Red.), Wokót Jedwabnego (ss. 353-459). Warszawa: IPN - Komisja Ścigania Zbrodni przeciwko Narodowi Polskiemu.

Santner, E. L. (1992). History beyond the Pleasure Principle: Some thoughts on the representation of trauma. W S. Friedländer (Red.), Probing the limits of representation. Nazism and the "Final Solution". Cambridge, Mass., London: Harvard University Press. 
Senechal de la Roche, R. (1996). Collective violence as social control. Sociological Forum 11(1: March), 97-128.

Senechal de la Roche, R. (2001). Why is collective violence collective?. Sociological Theory 19(2: July), 126-144.

Sereny, G. (2002). W stronę ciemności. Rozmowy z komendantem Treblinki. (J. K. Milencki, Tłum.). Warszawa: Cyklady.

Skibińska, A. (2011a). „Dostał 10 lat, ale za co?”. Analiza motywacji sprawców zbrodni na Żydach na wsi kieleckiej w latach 1942-1944. W B. Engelking, \& J. Grabowski (Red.), K. Persak (Wstęp), Zarys krajobrazu. Wieś polska wobec zagłady Żydów 1942-1945 (ss. 313-444). Warszawa: Stowarzyszenie Centrum Badań nad Zagładą Żydów.

Skibińska, A. (2011b). Powroty ocalałych i stosunek do nich społeczeństwa polskiego. W F. Tych \& M. Adamczyk-Garbowska (Red.), Następstwa zagłady Żydów. Polska 1944-2010 (ss. 39-70). Lublin: Wydawnictwo Uniwersytetu Marii Curie-Skłodowskiej \& Żydowski Instytut Historyczny im. Emanuela Ringelbluma.

Sluzki, C. E., \& Ransom, D. C. (1976). Double bind. The foundation of the communicational aproach to the family. New York: Grune \& Stratton.

Smolar, A. (1986). Tabu i niewinność. W A. Smolar, Tabu i niewinność (ss. 185-225). (M. Lipiński \& H. Łuczywo, Wybór i Opracowanie). Kraków: Universitas. (Pierwodruk: „Aneks” 1986, nr 41-42, s. 88-133).

Snochowska-Gonzalez, C. (2013). Czy jesteśmy postkolonialni? O pewnym wrogim przejęciu. W J. Tokarska-Bakir (Red.), PL: tożsamość wyobrażona (ss. 256-277). Warszawa: Czarna Owca.

Spiegelman, A. (2010). Maus. Opowieść ocalonego. (P. Bikont, Tłum.). Kraków: Post.

Steinlauf, M. C. (1997). Bondage to the dead: Poland and the memory of the Holocaust. Syracuse: Syracuse University Press.

Steinlauf, M. C. (2001). Pamięć nieprzyswojona. Polska pamięć Zagłady. (A. Tomaszewska, Tłum.). Warszawa: Wydawnictwo Cyklady.

Stola, D. (1995). Nadzieja i zagłada. Ignacy Schwarzbart - żydowski przedstawiciel w Radzie Narodowej RP (1940-1945). Warszawa: Oficyna Naukowa.

Stoll, K. (2010). Hitler's unwilling executioners? The representation of the Holocaust through the Bielefeld Bialystok trial 1965-1967. W D. Bankier \& D. Michman (Red.), Holocaust and justice. Representation and historiography of the Holocaust in post-war-trials (ss. 159-193). Jerusalem, New York, Oxford: Yad Vashem \& Berghahn Books.

Stoll, K. (2012). Die Herstellung der Wahrheit. Strafverfahren gegen ehemalige Angehörige der Sicherheitspolizei für den Bezirk Biatystok. Berlin: De Gruyter.

Stryjek, T. (2011). „Wojna o pamięć” o wydarzeniach lat trzydziestych-pięćdziesiątych XX wieku w Europie Środkowej i Wschodniej w latach 2005-2010 - strategie polityki Litwy, Łotwy, Estonii, Ukrainy i Rosji. Kultura i Społeczeństwo, 55(4), 191-223.

Sznaider, N. (2011). Suffering as a universal frame for understanding memory politics. W M. Blaive, C. Gerbel, \& T. Lindenberger (Red.), Clashes in European memory. The case of communist repression and the Holocaust (ss. 239-254). Innsbruck, Wien, Bozen: Studien Verlag.

Szurek, J.-C. (2010a). Entre histoire et mémoire, quelles figures du témoin polonais? W J.-C. Szurek, La Pologne, les Juifs et le communisme. Paris: Michel Houdiard Éditeur. (Pierwodruk 2009: Juifs et Polonais 1939-2008, red. Jean-Charles Szurek i Annette Wieviorka, Albin Michel, Paris 2009, s. 486-521).

Szurek, J.-C. (2010b). Le camp-musée d'Auschwitz en 1989. W J.-C. Szurek, La Pologne, les Juifs et le communisme (ss. 11-29). Paris: Michel Houdiard Éditeur.

Szurek, J.-C. (2010c). Les effets de l'occupation soviétique de 1939-1941 sur les rapports judéo-polonais. Réponse à Alexandre Smolar. W J.-C. Szurek, La Pologne, les Juifs et le communisme (ss. 173-193). Paris: Michel Houdiard Éditeur.

Szurek, J.-C., \& Korzec, P. (1989). Jews and Poles under Soviet Occupation (1939-1941). Conflicting interests, Polin (4), 204-225.

Szymkowiak, 0., \& Wilczyk, W. (2014, grudzień 17). „Żydy do pieca”. Nie wiecie, o jaki piec tu chodzi? Z Wojciechem Wilczykiem rozmawia Olga Szymkowiak. Gazeta Wyborcza, s. 18.

Świda-Ziemba, H. (2010). Hańba obojętności. W A. Michnik (Wybór, Wstęp i Opracowanie), Przeciw antysemityzmowi (1939-2008) (T. 3, ss. 143-155). Kraków: Universitas. (Pierwodruk: „Gazeta Wyborcza”, 17 sierpnia 1998, s. 14-16). 
Tokarska-Bakir, J. (2004). Żydzi u Kolberga. W J. Tokarska-Bakir, Rzeczy mgliste. Eseje i studia (ss. 49-72). Sejny: Pogranicze.

Tokarska-Bakir, J. (2008). Legendy o krwi. Antropologia przesądu. Warszawa: W.A.B.

Tokarska-Bakir, J. (2012a). Suppressio veri, suggestio falsi. Dzieje relacji Ryszarda Maja. W J. Tokarska-Bakir, Okrzyki pogromowe. Szkice z antropologii historycznej Polski lat 1939-1946 (ss. 231-242). Wołowiec: Czarne.

Tokarska-Bakir, J. (2012b). Wspólnota wstydu. W Ł. Baksik, Macewy codziennego użytku [Matzevot for everyday use] (ss. 7-9). Wołowiec: Czarne.

Tokarska-Bakir, J. (2014). Komentarz do badań dr Jolanty Ambrosewicz-Jacobs. Nigdy Więcej, (21(wiosna-lato)), 39-41.

Tokarska-Bakir, J., \& Grudzińska-Gross, I. (2012). Między brakiem a nadmiarem. Z Ireną Grudzińską-Gross rozmawia Joanna Tokarska-Bakir. Studia Litteraria et Historica, 1, 1-8. http://dx.doi.org/10.11649/slh.2012.007

Trachtenberg, J. (1997). Diabet i Żydzi. Średniowieczna koncepcja Żyda a wspótczesny antysemityzm. (R. Stiller, Tłum.). Gdynia: Uraeus.

Tych, F. (1999). Długi cień Zagłady. Szkice historyczne. Warszawa: ŻIH IN-B.

Urynowicz, M. (2009). La Délégation du Gouvernement de la République Polonaise de Londres et le financement du Conseil d'aide aux Juifs (Zegota). W J.-C. Szurek \& A. Wieviorka (Red.), Juifs et Polonais 1939-2008 (ss. 79-93). Paris: Albin Michel.

Volkov, S. (1995). Antysemityzm jako kod kulturowy. W B. Breysach (Red.), B. Hański (Tłum.), Ze soba, obok siebie, przeciwko sobie. Polacy, Żydzi, Austriacy i Niemcy w XIX i na początku XX wieku (ss. 7-41). Kraków: Znak.

Walicki, A. (2013). Dzieje antykomunistycznej obsesji. W Od projektu komunistycznego do neoliberalnej utopii (ss. 199209). Kraków: Polska Akademia Nauk \& Universitas.

Wat, A., \& Miłosz, C. (1990). Mój wiek. Pamiętnik mówiony. (L. Ciołkoszowa, Red., C. Miłosz, Przedmowa). Warszawa: Czytelnik.

Wóycicka, Z. (2002). Polacy na kozetce, czyli rozważania nad książką Michaela C. Steinlaufa „Pamięć nieprzyswojona”. Kultura i Spoteczeństwo, (3), 175-180.

Wroński, P. (2014, styczeń 18-19). Biedni Polacy kontra mordercy Chrystusa. Gazeta Wyborcza, s. 4.

Wyka, K. (1985). Gospodarka wyłączona. W K. Wyka, Życie na niby (ss. 139-178). Warszawa: Książka i Wiedza. (Tekst z 1945 roku).

Zaleski, M. (2000). „Ludzie ludziom”...? „Ludzie Żydom”...? Świadectwo literatury? W A. Brodzka-Wald, D. Krawczyńska, \& J. Leociak (Red.), Literatura polska wobec Zagłady (ss. 89-103). Warszawa: ŻIH IN-B.

Zaremba, M. (2001). Komunizm, legitymizacja, nacjonalizm. Nacjonalistyczna legitymizacja władzy komunistycznej w Polsce. Warszawa: Wydawnictwo TRIO \& Instytut Studiów Politycznych PAN.

Zawadzka, A. (2009). Żydokomuna. Szkic do socjologicznej analizy źródeł historycznych. Societas / Communitas, (2), 199-243.

Zawadzka, A. (2014). Polska Walcząca. W W. Wilczyk, Święta Wojna (2009-2014) (ss. 10-16). Łódź, Kraków: Atlas Sztuki \& Karakter.

Zawadzka, A., \& Rossman, J. (1991). Tadeusz Zawadzki „Zośka”. Warszawa: Oficyna Wydawnicza „Interim”.

Zubrzycki, G. (2014). Krzyże w Auschwitz. Tożsamość narodowa, nacjonalizm i religia w postkomunistycznej Polsce. (P. Tomanek, Tłum.). Kraków: Nomos.

Żbikowski, A. (2004). Posłowie. W S. Willenberg, Bunt w Treblince. (A. Żbikowski, Posłowie i Przypisy). Warszawa: Biblioteka „Więzi”.

Żbikowski, A. (2006). U genezy Jedwabnego. Żydzi na Kresach Pótnocno-Wschodnich II Rzeczypospolitej. Wrzesień 1939-lipiec 1941. Warszawa: Żydowski Instytut Historyczny.

Żbikowski, A. (2011). Morderstwa popełniane na Żydach w pierwszych latach po wojnie. W F. Tych \& M. Adamczyk-Garbowska (Red.), Następstwa zagłady Żydów. Polska 1944-2010 (ss. 71-93). Lublin: Wydawnictwo Uniwersytetu Marii Curie-Skłodowskiej \& Żydowski Instytut Historyczny im. Emanuela Ringelbluma. 
Žižek, S. (2001). Wzniosły obiekt ideologii. (J. Bator \& P. Dybel). Wrocław: Wydawnictwo Uniwersytetu Wrocławskiego.

Žižek, S. (2008). The plague of fantasies, London, New York: Verso.

Żmijewski, A. (2013). Cmentarz wojenny wieś Skłoby. Cmentarz żydowski Szydłowiec. W J. Tokarska-Bakir (Red.), PL: tożsamość wyobrażona (ss. 278-340). Warszawa: Czarna Owca.

Żukowski, T. (2001). Mówić, nie mówiąc za wiele. 0 dyskusji w sprawie Jedwabnego. Bez Dogmatu, (47), 24-27.

Żukowski, T. (2008). Współzawodnictwo w nacjonalizmie. Spór między partią i Kościołem w roku 1966. Kwartalnik Historii Żydów, (4), 415-426.

Żukowski, T. (2010). Savoir-vivre. Ironiczne strategie w Spowiedzi Calka Perechodnika. Teksty Drugie, (6), 38-55.

Żukowski, T. (2012, październik 8). Sprawiedliwi - sposób dyskryminacji Żydów? Przekrój, ss. 20-22.

Żukowski, T. (2013). Wytwarzanie „winy obojętności” oraz kategorii „obojętnego świadka” na przykładzie artykułu Jana Błońskiego „Biedni Polacy patrzą na getto”. Studia Litteraria et Historica, 2, 423-451. http://dx.doi.org/10.11649/ slh.2013.018

Żukowski, T. (2014). Biografia z piętnem. O „Drewnianym karabinie” Tadeusza Różewicza. W P. Krupiński (Red.), Niepokoje. Twórczość Tadeusza Różewicza wobec Zagłady (ss. 30-52). Warszawa: Żydowski Instytut Historyczny im. Emanuela Ringelbluma.

\title{
Memory acquired. The conception of the Polish experience of the Holocaust as collective trauma in the light of a revision of the concept of bystander
}

\begin{abstract}
The paper provides a reconstruction and proposes the deconstruction of the conception of the Polish experience of the Holocaust as collective trauma. The analytical framework is based on the revision of concepts such as Polish witness (bystander/onlooker - according to Hilberg) and indifference on the part of Polish majority society towards the persecution and murder of the Jews. The text postulates that the concept of indifference as well as that of the non-Jewish witness (bystander/onlooker) be dropped from the standard terminology used when describing the Holocaust. It proposes that the concept of the non-Jewish witness (bystander/onlooker) be replaced by the concept of participating observer - with a different understanding from that established within cultural anthropology.

Thus, watching would be a form of activity, a way of having an influence on the events, of agency, and therefore participation. A significant part of my argument includes an attempt to address the question of the construction of watching during the Holocaust. From this it follows that watching constitutes the most basic form of power (droit de regard - according to Foucault and Bourdieu). Therefore, the question arises of whether or not one can describe the margins of the Holocaust within the terms of panoptic reality (le panoptisme - according to Foucault). A further question under consideration is whether one can depict the dominant majority as an unofficial authority wielding something akin to social control over the completion of the Holocaust understood as the German Nazi system of persecution and extermination of the Jews.

The argument also foregrounds the actual functions of the concepts of the non-Jewish witness (bystander/ onlooker) and indifference as well as the idea of the Holocaust as a trauma for the non-Jewish witness (bystander/onlooker). These functions resulted several times in the elimination of the historical concrete and its societal-cultural conditions from the field of vision. In this sense, the conception of unacquired memory (i.e. the Polish trauma of the Holocaust) would be a strategy for acquiring the memory of the Holocaust in such a way that it does not endanger the dominant narrative about the past and the identity of the majority. Furthermore, the paper proposes the deconstruction of the concept of Polish-Jewish dialogue by identifying the phenomena of false symmetry and false universalization that frequently result in defining anti-Semitism and the Holocaust within the categories of a groups conflicts. The inspiration to undertake such a critical analysis came from the paradigmatic work by Michael C. Steinlauf, Bondage to the Dead: Poland and the Memory of the Holocaust, published in 1997. (The Polish-language edition entitled Pamięć nieprzyswojona. Polska pamięć Zagłady [Memory unacquired. The Polish memory of the Holocaust] came out in 2000, translated by Agata Tomaszewska.)

Keywords: Polish trauma of the Holocaust (concept revision); witness to the Holocaust; bystander/onlooker (concept revision); indifference towards the Holocaust (concept revision); Polish-Jewish dialogue (concept revision); participating observer; panoptism; social control over the Holocaust; margins of the Holocaust; memory studies; anti-Semitic discourse; myth of Judeo-communism
\end{abstract}


This is an Open Access article distributed under the terms of the Creative Commons Attribution 3.0 PL License, which permits redistribution, commercial and non-commercial, provided that the article is properly cited. www.creativecommons.org/licenses/by/3.0/pl

(c) The Author(s) 2014/2015

Publisher: Institute of Slavic Studies PAS [Wydawca: Instytut Slawistyki PAN]

DOI: $10.11649 /$ slh.2015.009

Author: Elżbieta Janicka, Instytut Slawistyki PAN, Warsaw

Correspondence: sekretariat@ispan.waw.pl

This work was supported by the Polish Ministry of Science and Higher Education.

Competing interests: No competing interests have been declared.

SLH 3/4 2014/2015 | str. 227 